\title{
UNIONS AND LABOUR MARKET INSTITUTIONS IN EUROPE ${ }^{\dagger}$
}

\author{
Daniele Checchi (Università di Milano - Italy) \\ Claudio Lucifora (Università Cattolica del Sacro Cuore, Milano - Italy)
}

This version: March 2002

\begin{abstract}
We investigate the evolution of unionisation, considering both economic and institutional factors. While economists typically study the effects of labour market institutions treating unionisation as given, and focusing on rent-seeking motivations, in this paper we study how union membership is itself related to the economic environment and, in particular, to labour market institutions. If unions also provide insurance against income and/or unemployment risks, government policies aimed at increasing worker security can reduce workers' incentives to join unions. The empirical analysis, focussing on the evolution of union density in 14 European countries over the post-War period, suggests that labour market institutions are important in explaining the differences in unionisation patterns. The traditional view of unions as rent-seeking organisations receives limited support from the data. Institutions such as employment protection legislation, wage indexation, statutory minimum wages appear to crowd out unions, while institutional features that make it easier for unions to function (such as workplace representation and centralised wage bargaining) are empirically associated with higher unionisation. In the context of the ongoing debate on flexibility-oriented reforms and evolving European institutions such as the European Monetary Union (EMU), the European Social Charter (ESC) and more generally the system of welfare provisions - the results in this paper offer implications both for the design of European institutions as well as for future of trade unions in Europe.
\end{abstract}

\footnotetext{
t We thank Giuseppe Bertola for help in revising previous versions of this paper. We also thank, without implication: S.Nickell, J.Visser and the OECD for making some of the data we used available to us; and G.Corneo, R. Naylor, our two discussants, Tito Boeri and Jan van Ours, the Managing Editors, and an anonymous referee for very helpful comments. This paper has been written while Claudio Lucifora was visiting RSSS at the Australian National University whose hospitality is gratefully acknowledged. Financial support from Italian CNR is gratefully acknowledged. Usual disclaimers apply.
} 


\section{Introduction}

Trade unions have existed since the industrial revolution, but have evolved rather differently in different countries over the post-war period. While there are several ways of measuring union presence and union activity on the labour market, still it should be acknowledged that a large number of workers in industrialised countries are member of a trade union, pay union dues, have their pay set through collective contracts and participate in strikes and other forms of collective actions. Therefore, the question of why do individuals join unions and what are the likely implications for policy seem to be highly relevant.

The contribution of this paper to a better understanding of the role of unions is twofold. First, unions are considered as economic agents which supply private and collective services to their members, compete for membership shares, are financed by their members' contributions, and can be effective only if many workers endorse their actions. This is at variance with most of the literature which considers unions simply as historically given institutions and investigates the effects of 'monopoly' unionism on (un)employment and, more generally, on economic performance (Nickell, 1997 and 1999; Blanchard and Wolfers, 2000).

Second, we extend the traditional view of unions as mainly engaged in rent-sharing behaviour, to encompass also an alternative view in which unions can perform useful roles, not fulfilled by markets or government institutions. In this perspective, the overall effect of unions has to be assessed against a more complex framework characterised by risk averse individuals, imperfect competition, missing markets and extensive government intervention. The above issues though conceptually important are, ultimately, an empirical question with some important policy implications. While studying the theoretical features underlining unions growth and decline, we also empirically investigate the competing hypotheses and discuss alternative scenarios based both on country heterogeneous features as well as institutional variety. We focus our analysis, in particular, on the evolution of union density (the share of union members among dependent workers) -- for which comparable cross-country data is available -- in a number of European countries in the post-war period and explore the overall relevance of unions in the economy in terms of both economic and institutional factors (and their interactions).

As the empirical evidence shows unionisation patterns differs remarkably -- both in levels and trends -- between Europe and North America, and also within European countries. In general, membership levels have been higher in Europe (and in some countries within Europe) -- where the political environment has been more favourable to the role of unions -- as compared to the US -where unions have been mainly operating at the labour market level rather than in the political arena. These differences coupled with the relevance of unions for economic performance in industrialised countries, beg for an explanation and raise a number of questions which we address in the present paper. Namely, is there a diffused and continued decline in unionisation rates and what are the driving forces? Are economic forces emerging from increasing competition and deeper integration of industrialised economies going to impact on unionisation patterns? What are the interactions between the institutional setting regulating the functioning of labour and product markets and the role of unions in the economy? Are institutional reforms at the European level likely to affect the role and relevance of unions?

We first discuss the theoretical implications of why workers join trade unions. Unions can thrive and exist only if workers choose to be their members, and economic incentives to do so should be quite relevant in determining union density. In the traditional literature the main incentive to join the union lies in the appropriation of employer rents originating in the product market and in their distribution to members. In this context, unions -- like any other monopolist -- by controlling the labour supply end up distorting relative prices, reducing employment, and generating efficiency losses and poor economic performance (Boeri, Brugiavini and Calmfors 2001). We shall refer to the above as the "bad view" of unionism.

However, when considering the benefits and costs of membership, we also pay attention to a view of unionisation that consider individual membership as a response to inadequate insurance against unemployment and labour income risks (Agell 1999 and 2000). This approach views union formation 
as a (second best) optimal behaviour for risk averse individuals face to market failures or government intervention. The latter, given the useful role played by unions, is considered here as a "good view" of unionism.

Interestingly, the two competing views of unionism have quite different implications. For example, product market regulation and protection from international competition should be associated with higher rents and -- to the extent that collective action is more effective than individual action -higher unionisation levels. Conversely, deregulation and increasing competition, by lowering rents, could reduce workers' incentives to join unions (Blanchard and Giavazzi, 2001; People, 1998). Since the most regulated and protected sector in the economy is the public sector - provided that there is low substitution between public and private services - we expect that the rents associated to public sector jobs ought to increase unionisation (Freeman, 1984; Algan et al., 2002). Accordingly, we include in our regressions some variables meant to capture the existence of rents in the economy (Scarpetta, 2002).

Besides business cycle considerations also the institutional setting, by altering the value of union membership, should be relevant for unionisation patterns. That is if union density responds to economic incentives, it should also react to the institutional environment. The benefits and the costs of union membership can be contrasted with alternative scenarios according to whether the market or the State provide a wide range of services to the worker. Empirically this view is supported if institutions and macroeconomic conditions -- that make it more desirable or easier for unions to provide insurance -- are associated with higher union density. Conversely, union density should be lower (or less necessary) when insurance is already provided by a country's legislative framework (or less necessary). State-provided unemployment insurance, employment protection legislation and wage indexation -- just to name a few -- by reducing labour market risks can make unions redundant. Conversely, institutions such as workplace representation or centralisation of bargaining, by making it easier for unions to perform their economic role can foster union membership.

To illustrate this better, let us consider unemployment insurance under different administrative setting in administering the schemes. Higher unemployment, when unemployment benefits are paid by the State, can be expected to reduce union membership since unemployed workers have no reason to pay union membership fees. In some countries (Finland, Belgium, Sweden and Denmark), however, unemployment insurance schemes are run by trade unions and partially subsidised by the State (this is known as the 'Ghent' system). Hence, in this context, higher unemployment by raising the value of union membership may induce a positive relationship and increase unionism. In other words, the association between labour market performance and unionisation depends on the scope and design of the institutional setting, in this case unemployment insurance schemes, which might be seen as 'complementing' (i.e. under the 'Ghent' system) or 'substituting' (i.e. when paid by the State) the insurance role of unions.

Alternatively, if we consider the real wage protection granted by the unions through collective bargaining, a different role can be expected whether an automatic system for wage indexation (covering all workers) is in place or not. As opposed to the previous example, higher inflation may lower the value of union bargaining activity, thus inducing a negative relationship. Also in this case, institutions may work as 'substitute' to union bargaining activity (i.e. when wage indexation mechanism are in place), or 'complement' if real wage protection is easily extended to all workers (i.e. when wages are bargained centrally or mandatory provision for collective contract exist). Other examples will be discussed as we go along, and we will bring such considerations and their policy implication to bear on the empirical analysis. Accordingly, we include in our regressions a large set of (time-varying) institutional variables -- both complement and substitute -- meant to capture the legislative environment in which individual make their choices (Nickell, 1997 and 1999; Blanchard and Wolfers, 2000). In either case, the interaction between the economic environment and workers' decision to join the union makes it difficult to view unionisation as given, independently of other institutional features. Both the "bad" view of unions, and the "good" view, should lead researchers to consider unionisation as variable to be explained by economic and institutional factors. 
Useful policy insights can also be derived from the above discussion. For example, to the extent that the "good" view of unions is relevant, then "complementary" institutions (i.e. those that make it easier for unions to operate) are to be considered beneficial, as they lower the costs of setting up institutions dealing with market failures. Similarly, the finding that unions are crowded out by "substitutable" institutions introduced by benevolent governments (as much as the development of suitable insurance markets, or macroeconomic stability might as well be desirable) would just confirm the view that unions play a welfare-enhancing role. Conversely, if the alternative "bad" view is correct, then the existence of "complementary" institutions (such as workplace representation or centralisation of bargaining) and their policy appeal are more controversial. Indeed, by making it easier for unions to restrict labour supply, the latter result in having the same implications in terms of efficiency losses, just like any other restriction to competition (i.e. they may benefit union members and employed workers as a group, but impose even bigger losses on other economic agents). In this context, also "substitutable" institutions may be as bad, for they may simply replace unions with similarly inefficient constraints (employment protection, unemployment insurance, and other policies advocated by workers' representatives).

These alternative explanations are not easy to assess empirically, since we might expect that a genuine demand of protection from labour market risks is likely to coexist with some rent-seeking behaviour and insider's effects. While the latter may convey the impression that it might be difficult to discriminate between the "good" and the "bad" view of unionism, nevertheless, we shall rely on the theory and the empirical analysis to assess their relative importance. What it is more difficult to assess, however, is to what extent there are costs in terms of productive efficiency involved in unionisation, or whether unions are able to provide security more efficiently than markets or State intervention. The latter questions, whose answer is likely to depend on the complex interactions existing between economic features and policy-making, are regrettably beyond the scope of the present paper.

Moreover, it should be said that while we are aware that institutions themselves might be endogenous (in the long run), given the data used and the cross-country focus, it is difficult in the context of the present paper to deal with these matters empirically. Nevertheless, we believe that focusing on individual workers' motivation for joining the unions offers interesting insights into the determinants of union density and into its interactions with the economic and institutional environment.

In practice, we find that labour market institutions are important in explaining the differences in unionisation patterns and also that country-specific features need to be taken into consideration. Policies such as employment protection legislation, wage indexation, statutory minimum wages - ceteris paribus - appear to crowd out unions thus impacting negatively on unionisation. Conversely, institutional features that make it easier for unions to function, such as workplace representation, centralisation of bargaining, have a positive effect. The results concerning the traditional view of unions as being mainly involved in rent-seeking activities to increase membership are more controversial. On the one hand, it appears that unions have been very successful in extracting rents and increasing membership in public sector jobs; on the other hand, the effects of decreasing rents on falling membership, as implied by product market deregulation and increasing openness of the economy, does not receive strong empirical support in the present analysis.

As always, empirical results have to be interpreted with care. Optimality of labour market institutions vis-à-vis the role of unions is not easy to assess in an imperfect world, and unions may or may not be beneficial for economic performance. Nevertheless, in the context of the ongoing debate concerning the flexibilisation of European labour markets and the role of institutions which have been or are being designed to regulate the functioning of both product and labour markets - such as the European Monetary Union (EMU), the European Social Charter (ESC) and more generally the system of welfare provisions - we believe that our results offer implications both for the design of European institutions as well as for future of trade unions in Europe.

In the next section we discuss in more detail theoretical reasons why union membership can be influenced by the institutional context and we review the relevant literature. Section 3 presents the data 
and the stylised facts concerning unionisation patterns in post-war Europe. Section 4 reports the main set of results of the empirical analysis, while in section 5 we account for the different patterns across countries. Details of the background theoretical model, data and variable description as well as a large part of our econometric analysis, are reported in the Appendices.

\section{Why do unions exist ? The economics of unions and institutions}

More than one century ago, Sidney and Beatrice Webb gave the following definition of a union: " $A$ trade union, as we understand the term, is a continuous association of wage earners for the purpose of improving the conditions of their employment" (Webb and Webb 1894, p.1). More than a century ago, this definition already conveyed the modern view of unions as a coalition of workers meant to strengthen their hand in bargaining with their counterparts. However, different types of unionism have developed under different institutional settings. Remarkable differences can be observed across North America and Europe (especially Continental Europe). In the former, firms become unionised only after thirty percent of workers have signed a petition calling for an election and half of the workers have voted in a ballot for union admission (Kremer and Olken 2001). Thus workers can choose between union and non-union workplaces (or, using a Tiebout analogy, choose to become member with their feet), thus inducing self-sorting of the workers that renders it difficult to evaluate the outcomes of union presence (Card 1998, Farber 2001). In Europe, however, unions provide services that are mostly public goods, since mandatory or de facto extension of collective contracts and several other provisions are in place. Most workers are going to be covered by the effects of collective contracts - at the national, sectoral, occupational or regional level - irrespective of their union affiliation. In such a context, it is not easy to account for union membership in terms of self-interested behaviour (see Box 1 for alternative explanations). Unions, however, do also provide a number of excludable goods and services to their members beyond collective bargaining. That is a variety of services such as legal and pension advice, grievance and promotion procedures, (preferential) manning and shift-work negotiation, subsidised access to medical aid, pension and insurance schemes are in general available to union members (Booth and Chatterji 1995). 
The literature proposes several models of union membership. The main problem faced by this literature is how to solve the paradox of free riding when membership is costly and the results of union activity are available to any worker at no cost (i.e. unions provide collective goods). One line of research has followed the so-called social custom approach. If unions provide monopolistically a reputation for 'good societal values' (like being supportive), and a good reputation is valuable for workers, one may expect positive density rates in equilibrium even without resorting to workers' heterogeneity (Booth 1985). When workers are differentiated according to the value they assign to reputation, one can derive threshold effects and can jointly determine union density and bargained real wage. In addition pro-union legislation and lower membership dues increase equilibrium union density (Naylor and Cripps 1993). If we consider strategic incentives to unionise, firm managers and union activists obviously have opposite goals: as a consequence, equilibrium union density is affected by the dimension of the workers' surplus and by the degree of bargaining centralisation (Naylor and Raaum 1993, Corneo 1995). Finally, if we consider that the reputation enjoyed by a worker if a function of the size of 'believers' (Akerlof 1980), we may obtain either positive or negative impact of pre-existing density on the individual decision to join, according to the dominance of 'conformist' or 'elitist' attitude among workers (Corneo 1997).

An alternative line of research has considered the possibility of unions providing private goods to their members, especially in terms of employment protection. When unions are able to bargain over layoff procedures and to obtain preferential treatment for their members (in that non union members are the first to be laid off), workers join the union in order to obtain (partial) insurance against the unemployment risk. If they are heterogeneous in terms of risk aversion, more riskaverted workers join the union and, other things being constant, an increase in aggregate unemployment risk raises union density (Booth 1984). ${ }^{1}$ When the labour demand has an erratic component and firms follow a last-in first-out rule in layoffs, membership increases with past employment, because seniority rules are applied in union voting as well (Burda 1990, Grossman 1983). Also in this framework, an exogenous shock to employment probability lowers the value of union insurance, thus decreasing the expected gain of becoming a union member (Jones and McKenna 1994). Finally, if in addition to employment protection and wage differential compression unions provide a higher probability of on-the-job training, less skilled workers are more likely to unionise (Acemoglu, Aghion and Violante 2000). Whenever unions offer exclusive services to their members, e.g. in the form of advice on retirement plans and legal support in disputes with employers, union density is obviously increasing with the quality of the services provided (Booth and Chatterji 1995).

Overall, both strands of the theoretical literature provide testable predictions for union density. In the first case, density should be correlated with solidaristic values (no matter how measured), with labour productivity (since it increases available surplus) and with bargaining centralisation. In the second case, membership is correlated with unemployment risk (the sign of correlation depending whether we are considering the firm level or the aggregate one) and labour force composition (since insiders have a comparative advantage in adopting LIFO procedures). Both approaches predict a negative impact of unionisation cost, and this could be extended to include legislative support to union activity at work-place level.

Even if we acknowledge that - under different models of unionism and institutional settings - trade unions perform a wide range of tasks in the functioning of the economic system, still the standard approach to the economics of unions has mainly focussed attention on the "bad" view of unionism, that is rent extraction behaviour. In that framework, unions face a downward-sloping demand for labour and collective bargaining makes it possible to increase the wage bill by increasing wages and lowering employment: the higher wages for incumbent workers more than compensate for lower employment, and employment losses are small when labour demand does not respond strongly to wage variations (or, is inelastic). While at the margin individual workers would be prepared to trade employment for wages lower than the collectively bargained one, this is not feasible for it would reduce inframarginal rents. Hence, in this setting unions behave as monopolists, raising wages, reducing employment, and introducing a deadweight loss.

An alternative "good" view of unionism, as provider of (second best) redistribution against uninsurable risk (Agell 2000) has received less attention in the literature, and deserves to be discussed in more detail. Consider a labour market where individuals are risk averse and heterogeneous with respect to

\footnotetext{
${ }^{1}$ However the coeteris paribus assumption is untenable when the joint determination of wage and density is considered: "The two facets of wage setting, the political one and the mechanical, work in opposite directions as membership grows. The political facet has wage increasing to satisfy the preferences of the shifting median voter, whereas the mechanical facet has wage declining as the members willing to work increase" (Booth 1984, p.893). Booth and Chatterij 1995 present a similar model, where membership is increasing in union bargaining power and alternative wage (and therefore negatively related with unemployment).
} 
employment probability. One may think of differences in job search (ability or intensity), or in retention probability. ${ }^{2}$ Unions provide their members with excludable services that increase their employment probability; examples are information on job opportunities, opposition to firing, off-the-job training. Unions act as monopolist wage setters and maximise the utility of the median member, so that the negotiated wage will not necessarily coincide with that preferred by the median worker. Since employer cannot discriminate, the negotiated wage is the same for both members and non-members.

Each worker evaluates cost and benefit of becoming a union member: costs are union dues, whereas (expected) benefits depend on employment probabilities. Note that without this excludable good since wages are the same between members and non-members - free riding would drive membership to zero and we would obtain the payment of competitive wages. Since joining the union increases employment probability, then individuals with low employment probability will have the greater benefit. In this perspective, unions provide a partial insurance against unemployment risk, which is demanded by less employable workers. ${ }^{3}$ Membership levels are determined by the optimal decisions of workers: at the margin, there will be a worker who is indifferent between joining and not joining the union, since for him or her the expected benefits of membership are equal to its costs.

In this context, higher risk or more pronounced risk aversion raise the (net) benefit of membership, and imply higher union density. ${ }^{4}$ Labour market institutions can play straightforward roles in such a framework. For example, other things equal, an increase in the ability of the union to provide employment protection or income insurance increases the value of membership, and implies higher union density. Conversely, higher employment or income protection reduces risks for incumbent workers, makes union-supplied protection less valuable, and reduces membership. In the case of employment protection, labour market institutions that are "complementary" to union activity, like the right to be defended by union officers in legal litigation, tend to increase union membership. Conversely, institutions that, independently from union membership status, operate so as to reduce workers' need to be protected by the unions (for example reducing the overall risk of unemployment for incumbent workers), by acting as "substitutes" to union activity determine a reduction in union membership.

A similar argument can be made with respect to unemployment benefit schemes. If union membership is associated with a higher expected income (because union offer unemployment insurance schemes, as in Ghent countries), workers with higher unemployment risks are more likely to join the union. ${ }^{5}$ Conversely, when unemployment benefits are provided unconditionally, union unemployment insurance schemes loose value and membership declines. More generally it can be argued that labour market institutions providing unconditional protection for the unemployed - ceteris paribus - will reduce the incentive to join the union, while insurance schemes that exclude non-members increase the expected gain from unionisation. Alternatively, with respect to income insurance, it could be argued that risk adverse workers are prepared to pay a premium (i.e. union dues) to be insured against (real) income variability. ${ }^{6}$ If union members rely on re-negotiation of wages to obtain some insurance, union

\footnotetext{
${ }^{2}$ We follow the model proposed by Booth (1984), in which workers are heterogeneous with respect to the alternative wage in the non-union sector (due to their different degree in risk aversion). Firms follow discriminatory rules for hiring (unions members are hired first), as it would occur in a closed shop environment. In a different context, Jones and McKenna (1994) model union membership dues as an insurance premium to reduce the impact of random shocks on job security.

3 Similarly, Acemoglu, Aghion and Violante 2000 assume that less skilled have an incentive to become union member because under firing restrictions firms find it convenient to train them.

${ }^{4}$ Booth (1984) shows that an equilibrium density exists. A formal model is provided in Appendix 1.

${ }^{5}$ Blanchflower et al. 1990 find that local unemployment is a significant predictor of regional membership regressions (Great Britain, 1984), and explain this effect as a consequence of union status reducing the risk of lay-off. Similar explanation is invoked for a similar result by Andrew and Naylor 1994 (referred to the 1980-84 period, Great Britain).

6 Similarly real wage fluctuations could be induced by productivity fluctuations (technological shocks, variation in intermediate input supplies, etc.) in a context of nominal wage setting.
} 
membership is valuable. However, when automatic indexation clauses are introduced, the benefit of renegotiation declines, and so does membership. ${ }^{7}$ Hence, any kind of automatic wage indexation mechanism - ceteris paribus - reduces the scope for union activity, thus making union membership less valuable. The value of any insurance mechanism, however, has to be cast against periods of high turbulence (i.e. oil shocks) and, for any given level of institution, also the value of union bargaining depends on its effectiveness to reduce income variability.

Finally, consider the supply of union activity. Unions collect membership dues to pay for staff and equipment, and use such factors to deliver protection to their members. The "technology" for doing that is in many ways influenced by institutional features such as the right to workplace representation, strikes regulations, procedures for workers recruitment and payment of union dues, and protection of union activists from discriminatory dismissals. Allowing the presence of union representatives in each workplace and protecting them from being laid-off because of their role, reduces the cost of union services and/or increases their effectiveness. ${ }^{8}$ Thus we can derive a prediction that labour market institution directed at lowering the cost of organising a union have - ceteris paribus - a positive effect on membership.

It should be noted, however, that a number of existing labour market institutions that cannot be directly accounted for in the simple stylised framework outlined above. These range from: the structure of wage differentials, the degree of centralisation-corporatism and the existence of mandatory extension in collective bargaining agreements, as well as the provision of seniority rules (both in terms of pay or LIFO provisions in lay-offs), negotiated profit sharing schemes, manning ratios and general job conditions. Other cultural and historical factors are obviously relevant in determining the extent of union membership, but in our view they bear a limited explanatory power in terms of accounting for cross-country differences in European unionism (i.e. preference for collectivism and solidarity, ideological biases, traditional links with socialist parties, other historical reasons).

As to welfare effects, it is difficult to evaluate whether unions are superior to state-provided insurance in offering unemployment/inflation insurance schemes. On one side, worker-level organisation implies better monitoring of individual behaviour (for example in the effort of job search), which is always preferable whenever moral hazard and adverse selection situations can be detrimental to a good functioning of the scheme. On the other side, unions are historically a dependent labour movement, and therefore have problems in granting universal coverage, whereas state-provided schemes are more likely to extend coverage to other segments of labour force. On the whole it is hard to say whether state bureaucracy with extended universalism is better than union provision with limited coverage.

\footnotetext{
7 The Italian experience provides a paramount example of this occurrence. In 1983 the Italian government reduced the coverage of the indexation mechanism (scala mobile) that had been operating since 1958. While a referendum was called for to re-establish the indexation mechanism, Italian trade unions (CISL, UIL and a fraction within the biggest confederation of unions, the CGIL) opposed this choice, on the ground that full indexation was reducing unions' scope in wage bargaining. The referendum was then held in 1984, and expressed against the re-establishment of the old system.

8 There is empirical evidence of favourable effect of the institutional context onto union membership: Freeman and Pelletier 1990 show the significance of a "legal index" measuring the attitudes towards the unions of the government in place; Pehkonen and Tanninen 1997 use a step-variable measuring the change in the pro-union attitude of the government; Checchi and Corneo 2000 use a step-variable to control for the introduction of a worker charter favouring unionisation at workplaces.
} 


\section{Unionisation in Europe: Data and Stylised Facts}

Our analysis is constrained by limited availability of institutional information, which is scarce and often restricted to some point in time. We were able, however, to collect and organise consistently an extensive data set, covering 14 European countries over the post-war period. ${ }^{9}$

\subsection{Union density: availability of data and previous results}

There are alternative measures of union presence, among which the most widely used are union membership (the number of people supporting the union by paying union dues), union coverage (the number of people covered by collective contracts, independently from effective membership) and strike activity. Given the pecuniary cost of membership, the first variable is the one that better captures the demand for union representation: for active members value union presence more than the union dues they pay. The degree of coverage points to an alternative dimension of unions, namely the extent of bargaining (or alternatively, the degree of universalism in union claims). Finally, strike activity proxies the potential effectiveness of union threat.

In the light of the theoretical framework, we see membership as the variable that better captures the implied demand for social insurance. Thus we measure union presence as union density, that is the ratio of union members to employed workers. This variable includes active members - i.e. gainfully employed - while excludes unemployed or retired members. We take particular care about some changes occurred, over time in some countries, in the definition of membership. Data we use on union density cover the 1950-98 period (with few exceptions) ${ }^{10}$, while information on time-varying institutions is available from the 60's onwards. Henceforth while we cover the whole period in the descriptive analysis, we are restricted to post 1960's period for the econometric analysis. Data definitions and sources are fully described in Appendix 2.

Similar samples (with smaller country coverage and time span) have already been analysed by Western (1997), Lang and Scrugg (1999), Oskarsson (2001) and Checchi and Visser (2001). With respect to this literature, that typically controls for unemployment schemes administration ("Ghent" system) and workplace representation, we expand the set of institutions potentially affecting union density, by including several others indicators, such as: employment protection, unemployment benefit (both replacement rate and benefit duration), minimum wage legislation, mandatory extension of contracts, bargaining structure, tax wedge and product market regulation.

The existing literature has proposed alternative explanations for the dynamics of union density, which can be roughly grouped into different categories. First, business cycle factors typically include unemployment and inflation rates. Second, compositional effects such as sectoral employment shares, age, gender and skill composition of the labour force ${ }^{11}$. Third, selected institutional variables like Ghent-like unemployment subsidies and workplace representation (Freeman and Pelletier 1990; Oskarsson 2001), the degree of wage setting centralisation (Ebbinghaus and Visser 1999), the degree of financial openness and political attitude of governments (Lange and Scrugg 1999). While taking into account economic factors and compositional effects, in the reminder of the paper we shall focus on the effects of a wider set of labour market institutions on union density.

\footnotetext{
9 The countries are: Austria, Belgium, Denmark, Finland, France, Great Britain, Ireland, Italy, the Netherlands, Norway, Spain, Sweden, Switzerland and Germany (West Germany until 1989). The data range from the 1950s to the end of the 1990s.

${ }^{10}$ Restricted samples for Belgium (1950-95), Denmark and Italy (1950-97) and Spain (1981-97).

11 See Van Ours (1992), for an analysis of compositional as well as cyclical factors on union membership applied to the Netherlands.
} 


\subsection{Classification of institutions and potential effects on union density}

Given our focus on the effects of institutions on the incentives for individual workers to join a union, we briefly review existing information on labour market institutions in the recent economic and industrial relations literature. We restrict our attention on explicit and quantifiable measures of institutional forces, in order to be able to measure their impact on union density. Restricting the scope in this way avoids excessive arbitrariness in defining the relevant institutions.

In the economic literature some institutional indicators have proved capable of explaining a great deal of differences in the structure and dynamics of wages and (un)employment across countries. ${ }^{12}$ Similarly, the industrial relations literature has stressed the importance of institutional arrangements in the rise or the decline of unions in western countries. ${ }^{13}$ While reviewing this extensive literature is beyond the scope of the present paper, we discuss some results that are relevant to our research. The other aspects, related to employment/unemployment and wage setting, are reported in box 2. We group existing institutions under different headings, as reported in table 1.

In the first group we consider different aspects of employment protection. If unions act as substitutes for employment protection, a negative impact is anticipated on union density, that is: the stricter is labour market regulation vis-à-vis dismissals, the lower the risk of unemployment for currently employed members, the lower will be the demand for union protection. ${ }^{14}$ However, if union shop stewards are at risk of being fired then employment protection, by lowering the cost of union activity in the workplace, may mitigate the negative impact of those measures on union density.

A second group of institutions include variables measuring the extent of subsidisation of unemployed, while in the third we consider mandatory extension of collective contracts (usually measured through union coverage $\mathrm{e}^{15}$ ) and statutory minimum wages. The effect of these two groups of institutional measures on union density can be ambiguous. On the one hand, unemployment benefits can be taken as an indicator of pro-labour attitudes of governments (effectively proxying for welfare provisions - see Checchi and Visser 2001) ${ }^{16}$, on the other hand, several authors have stressed the importance of a voluntary but publicly supported scheme of unemployment insurance directly administered by the unions or simply dominated by the union (Ghent system type of arrangements see Lange and Scrugg 1999, Ebbinghaus and Visser 1999, Checchi and Visser 2001, Oskarsson 2001, Lipset and Katchanovski 2001). ${ }^{17}$ However, if a compulsory system is administered by government agencies then demand for insurance provided by unions is expected to be lower.

\footnotetext{
12 See, among others, Bertola 1990, Layard, Nickell and Jackman 1991, Grubb and Wells 1993, Nickell 1997, Gregg and Manning 1997, Nickell and Layard 1999, OECD 1999, Garibaldi and Mauro 1999, Blanchard and Wolfers 2000, Belot and van Ours 2000, Boeri, Nicoletti, and Scarpetta 2000, Bertola, Blau and Kahn 2001.

13 See Hancke 1993, Visser 1993, Western 1997, Golden, Lange and Wallerstein 1997, Waddington and Whitston 1997, Lange and Scrugg 1999, Ebbinghaus and Visser 1999, Checchi and Visser 2001, Oskarsson 2001, Lipset and Katchanovski 2001, Traxler, Blaschke and Kittel 2001.

14 This may not necessarily be true when the risk of dismissal is unevenly distributed in the population (Saint Paul 1996). Under such a case, the effect on density could be reversed.

15 The extent of union coverage is usually tested in combination with a measure of union density (Nickell 1997, Nickell and Layard 1999, Blanchard and Wolfers 2000, Bertola, Blau and Kahn 2001), but the two variables are hardly jointly significant.

16 On the account that "...historical experience suggests that union movements have grown where unions control unemployment benefits, the labour market is centrally organised and social democratic parties with close ties to organised labour have been in power ..." (Western 1997, pg.87-88), some authors include left voting (or left share in Parliament seats) among the explanatory variables for union density (Western 1997, Lipset and Katchanovski 2001 - also Oskarsson 2001 includes left voting without finding any statistically significant effect). Similarly, some authors (Western 1997, Checchi and Corneo 2000) make use of strike activity as an explanatory variable for union density. Since we consider these variables as potentially endogenous, we use it only as additional controls in Appendix 4.
}

${ }^{17}$ See Holmlund and Lundborg 1999 for discussion of this issue. 
The fourth group of variables measures employee rights, that is, establishment-level workplace representatives and other forms of representation. This feature is sometimes pooled with employment protection and other measures (see Nickell and Layard 1999), but there is evidence suggesting that workplace representation per se can be very effective in raising membership (Hancké 1993) ${ }^{18}$, since it ensures that union services are available only to union members (Booth and Chatterij 1995). With respect to union density, it has been argued that it is the combination of bargaining and locally strong unions that can exert positive influence on the union density level, hence showing positive effects of (alternative) measures of workplace representation (Lange and Scrugg 1999, Ebbinghaus and Visser 1999, Oskarsson 2001).

The fifth group relates to institutional features of wage bargaining. As far as union density is concerned, a centrally organised union gains new members because of reduced managerial opposition, increased public recognition and easier access to sites and business. Evidence of positive effect of centralisation on density are reported in Western (1997) (associated with Left party representation in government), Lange and Scrugg (1999) (in combination with workplace access and Ghent-type unemployment benefits, yielding a single measure of "union compatible institutions"), Ebbinghaus and Visser (1999), Checchi and Visser (2001) (where the measure of centralisation combines the distribution of bargaining authority, vertical coordination, with the distribution of members, horizontal coordination), and Oskarsson (2001) (who combines indices of organisational inter-union coordination with measures of centralisation of wage bargaining).

The sixth group of institutions concerns labour taxation. Its effects on union density are less clear-cut from a theoretical point of view. To the extent that taxes on labour serve to finance public welfare provisions, by redistributing resources to marginal workers may reduce the insurance and risk-reducing role unions (Moore, Newman and Scott, 1989), in this respect union density could be expected to be negatively correlated with taxes. However, labour taxes may also imply a higher tax wedge and lower net wages, which may push workers to call for stronger union protection (Daveri e Tabellini, 2000). ${ }^{19}$

The seventh group of institutions is related to product market regulation. Standard theoretical analysis suggests that increased competition among firms in the national market (Blanchard and Giavazzi 2001) and the removal of barriers to external competition, by reducing the available economic rents, lowers bargained wages and raises - in the long run - employment prospects. Alternatively, since higher external exposure may induce higher economic volatility and uncertainty, a risk-reducing role by government redistribution or union protection might be desirable (Rodrik 1998). Empirical evidence also suggests that countries with highly regulated product market (mostly Mediterranean countries) also exhibit higher unemployment and a larger share of self-employment (Boeri, Nicoletti, Scarpetta 2001, Nicoletti, Scarpetta, Boylaud 2000, Nicoletti and Scarpetta 2001). Since product and labour market regulations strengthen each other, it may be hard to disentangle the relative (net) contribution of each variable for unionisation patters. On the basis of the above discussion, there are not clear-cut predictions about the effect of market regulation and openness on union density. To the extent that market regulation raises the available surplus and unions are perceived by workers as rent seekers (at the expenses of outsiders), it will benefit union formation. Alternatively, if the lowering of product market regulations and/or barriers to external competition are associated with higher labour market risks, the value of union protection can (positively) affect the demand for unions.

An additional feature, which has received little attention mainly due to lack of data, is wage compression that can be correlated with both unemployment and union density. In recent papers, Kahn (2000) and Bertola, Blau and Kahn (2001) have drawn attention to wage compression as a

\footnotetext{
18 A thoroughly discussion of the relevance of recruiting methods is provided in Waddington and Wiston 1997.

${ }^{19}$ High taxes are more likely to be found in social-democratic (pro-worker) political environments and, to the extent that our measures of "complementary" institutions do not appropriately control for pro-union policies, can be associated with higher union density.
} 
potential factor explaining the different unemployment performance of United States vis-à-vis Europe. In that framework, downward rigidity of low skilled wages would translate in lower employment opportunities for these workers. ${ }^{20}$ One problem with this explanation is that it overlaps with a number of significant labour market institutions (discussed above), making it difficult to separate out the relative contribution of minimum wages, mandated extension of wage bargaining and direct union activity (DiNardo, Fortin and Lemieux 1996).

\section{Box 2: Employment and wage effect of labour market institutions}

There is now a sufficiently robust evidence suggesting that employment protection per se does not raises unemployment, but may lower employment rates, job creation and unemployment turnover, thus increasing the share of long term unemployed people (Grubb and Wells 1993, Bertola 1990, Nickell 1997, Nickell and Layard 1999, OECD 1999, Garibaldi and Mauro 1999, Blanchard and Wolfers 2000). However Bertola, Blau and Kahn (2001), show a positive effect of employment protection on unemployment when it is interacted with different types of shocks (wage share, real interest rate, total factor productivity, change in inflation and youth population share - see table 9). Some measures of employment protection have also some impact on price setting inertia, thus rising unemployment hysteresis (Layard, Nickell and Jackman 1991, pg.417 ). With respect to the second group of institutions measuring the extent of subsidisation of unemployed, the consensus among economists is that they increases unemployment because they lower search intensity (Nickell 1997, Nickell and Layard 1999, Blanchard and Wolfers 2000). Similarly, mandatory extension of wage bargaining and/or legislated minimum wages could have positive impact onto unemployment because of the effect on the average wage level and downward flexibility of wages (especially among unskilled workers and first job seekers - see Dolado et al. 1996, Bertola, Blau and Kahn 2001). The presence of these institutions increases both the bargained wage (through a reduced effect of unemployment onto wage) and its persistence, thus raising unemployment hysteresis. In addition, indexation schemes reduce stickiness of nominal wages, and thus increase real rigidity, even without affecting the NAIRU (Layard, Nickell and Jackman 1991).

Employee's rights are often mixed with employment protection (Nickell and Layard 1999). While there are no strong theoretical arguments to expect direct effects on unemployment, some impact can be detected in wage setting, when proxied by employment share in firms with less than 100 employees: a higher share of employees in small size firms induces more wage flexibility and therefore less unemployment and hysteresis (Layard, Nickell and Jackman 1991). The (mandated) existence of work councils in most countries may improve cooperative attitudes among the workers, and therefore productivity (Rogers and Streeck 1995).

With respect to institutional aspects of wage bargaining, starting from the seminal paper by Calmfors and Driffill (1988), it has gone uncontested that centralised bargaining induces less unemployment, via wage moderation (alternative channels of influence are discussed in Calmfors 1993). Evidence of positive effect on unemployment of alternative measures of centralised wage setting are reported in several papers (Nickell 1997, Nickell and Layard 1999, OECD 1999, Bertola, Blau and Kahn 2001). With respect to wage setting, bargaining centralisation and inter-union/inter-firm coordination work in the same direction, by raising wage elasticity to unemployment and reducing the NAIRU (Layard, Nickell and Jackman 1991, pg.418ss).

Labour taxation has more or less obvious negative effects on employment rates (Nickell 1997, Nickell and Layard 1999, OECD 1999, Garibaldi and Mauro 1999, Bertola, Blau and Kahn 2001), which can be attenuated by centralised wage setting (Daveri and Tabellini 2000). With respect to wage setting, the higher is the real wage resistance, the higher will be labour costs and the related employment loss (Layard, Nickell and Jackman 1991).

${ }^{20}$ Card 1998 has raised doubts on this traditional explanation, showing the extent of self-selection among union members. 
Table 1 - Classification of labour market institutions

\begin{tabular}{|c|c|c|c|}
\hline LABOUR MARKET INSTITUTIONS & $\begin{array}{c}\text { EFFECT ON } \\
\text { EMPLOYMENT }\end{array}$ & $\begin{array}{c}\text { EFFECT ON } \\
\text { WAGES }\end{array}$ & $\begin{array}{c}\text { EXPECTED EFFECT } \\
\text { ON DENSITY }\end{array}$ \\
\hline $\begin{array}{l}\text { Employment protection: } \\
\quad * \text { advanced notice for dismissal } \\
\quad * \text { protection against unfair dismissal } \\
\quad * \text { regulation of fixed term contract } \\
\quad * \text { temporary work agency } \\
\quad * \text { working time regulation }\end{array}$ & $\begin{array}{l}\text { limited effect on } \\
\text { unemployment level } \\
\text { significant effect on } \\
\text { (un)employment } \\
\text { composition and on } \\
\text { net job creation }\end{array}$ & $\begin{array}{c}\text { increases } \\
\text { bargaining power } \\
\qquad \begin{array}{c}\Omega \\
\text { increases bargained } \\
\text { wage }\end{array}\end{array}$ & $\begin{array}{l}\text { substitute for } \\
\text { union protection } \\
\Omega \\
\text { less incentives to join } \\
\text { the union }\end{array}$ \\
\hline $\begin{array}{l}\text { Unemployment benefit: } \\
\quad * \text { replacement rate } \\
\text { * benefit duration } \\
* \text { administrative responsibility on unions }\end{array}$ & $\begin{array}{c}\text { increases } \\
\text { unemployment }\end{array}$ & $\begin{array}{c}\text { increases } \\
\text { outside option } \\
\sqrt{\Omega} \\
\text { increases bargained } \\
\text { wage }\end{array}$ & $\begin{array}{l}\text { reduces job insecurity } \\
\text { but } \\
\text { reward unions if they } \\
\text { have administrative } \\
\text { responsibility }\end{array}$ \\
\hline $\begin{array}{l}\text { Extension of bargaining outcomes: } \\
\text { * wage indexation } \\
\quad \text { * coverage } \\
\text { * mandatory extension } \\
\text { * minimum wages }\end{array}$ & $\begin{array}{l}\text { increases } \\
\text { unemployment } \\
\text { (sometimes in } \\
\text { combination with } \\
\text { union density) }\end{array}$ & $\begin{array}{l}\text { lowers impact of } \\
\text { unemployment on } \\
\text { bargaining power } \\
\Omega \\
\text { increases bargained } \\
\text { wage }\end{array}$ & $\begin{array}{l}\text { incentive to free-ride } \\
\text { on union outcomes } \\
\qquad \begin{array}{c}\Omega \\
\text { less incentives to join } \\
\text { the union }\end{array}\end{array}$ \\
\hline $\begin{array}{l}\text { Employee rights: } \\
\quad * \text { representation rights } \\
\quad * \text { work council } \\
\quad * \text { voting rights }\end{array}$ & $\begin{array}{c}\text { no effect on } \\
\text { unemployment levels }\end{array}$ & $\begin{array}{l}\text { increases } \\
\text { bargaining power } \\
\qquad \Omega \\
\text { increases bargained } \\
\text { wage (and sometimes } \\
\text { productivity) }\end{array}$ & $\begin{array}{l}\text { stricter contact with } \\
\text { union representatives } \\
\Omega \\
\text { reduces the cost of } \\
\text { unionising workers }\end{array}$ \\
\hline $\begin{array}{l}\text { Bargaining structure: } \\
\quad * \text { coordination among unions } \\
\quad * \text { coordination with employer representatives } \\
\quad * \text { centralisation }\end{array}$ & $\begin{array}{l}\text { reduces } \\
\text { unemployment } \\
\text { (possibly in a } \\
\text { non-linear way) }\end{array}$ & $\begin{array}{l}\text { internalises adverse } \\
\text { effect of high wages } \\
\rrbracket \\
\text { reduces bargained } \\
\text { wage }\end{array}$ & $\begin{array}{l}\text { lowers managerial } \\
\text { opposition and inter- } \\
\text { union competition } \\
\Omega \\
\text { reduces the cost of } \\
\text { unionising workers }\end{array}$ \\
\hline $\begin{array}{l}\text { Tax wedge: } \\
* \text { payroll taxes } \\
* \text { income taxation } \\
* \text { consumption taxation }\end{array}$ & $\begin{array}{l}\text { increases } \\
\text { unemployment if } \\
\text { higher labour costs are } \\
\text { required to sustain } \\
\text { welfare provision }\end{array}$ & $\begin{array}{l}\text { higher wage } \\
\text { pressure under real } \\
\text { wage resistance }\end{array}$ & $\begin{array}{l}\text { stronger demand for } \\
\text { union protection } \\
\text { but } \\
\text { higher provision of } \\
\text { welfare benefits }\end{array}$ \\
\hline $\begin{array}{l}\text { Product market regulation: } \\
* \text { entry regulation } \\
* \text { state intervention } \\
* \text { barriers to trade and investment }\end{array}$ & $\begin{array}{l}\text { reduced firm } \\
\text { competition increases } \\
\text { unemployment (higher } \\
\text { rents and lower } \\
\text { competitiveness) }\end{array}$ & $\begin{array}{l}\text { higher rents } \\
\text { increases } \\
\text { bargained wage }\end{array}$ & $\begin{array}{l}\text { higher rents may } \\
\text { trigger union } \\
\text { formation in order to } \\
\text { boost wage share }\end{array}$ \\
\hline $\begin{array}{l}\text { Wage compression: } \\
\text { * decile ratios in earnings distribution } \\
\text { * sectoral wage differential }\end{array}$ & $\begin{array}{c}\text { increases } \\
\text { unemployment } \\
\text { for less skilled workers }\end{array}$ & $\begin{array}{c}\text { reduces pay flexibility } \\
\sqrt{\Omega} \\
\text { increases bargained } \\
\text { wage }\end{array}$ & $\begin{array}{l}\text { increased unionisation } \\
\text { among low skilled } \\
\text { but } \\
\text { declines among high } \\
\text { skilled workers }\end{array}$ \\
\hline
\end{tabular}




\subsection{Some stylised facts}

In figure 1 we plot the evolution of (aggregate) unionisation for 14 European countries since the postWar period. The solid line shows the employment weighted average of net union density, and the two dotted lines report variation of national union density levels around the average. Unionisation patterns exhibit first a moderate decline, from an average of 45 percent in the early 1950s, followed by a rapid increase throughout all the 1970 s and a steady decline from the 1980s onwards ${ }^{21}$. The dotted lines suggest the existence of a significant dispersion - which has been increasing over time - across countries, from 12 percent in France to more than 80 percent in Sweden in the mid $1990 \mathrm{~s}^{22}$.

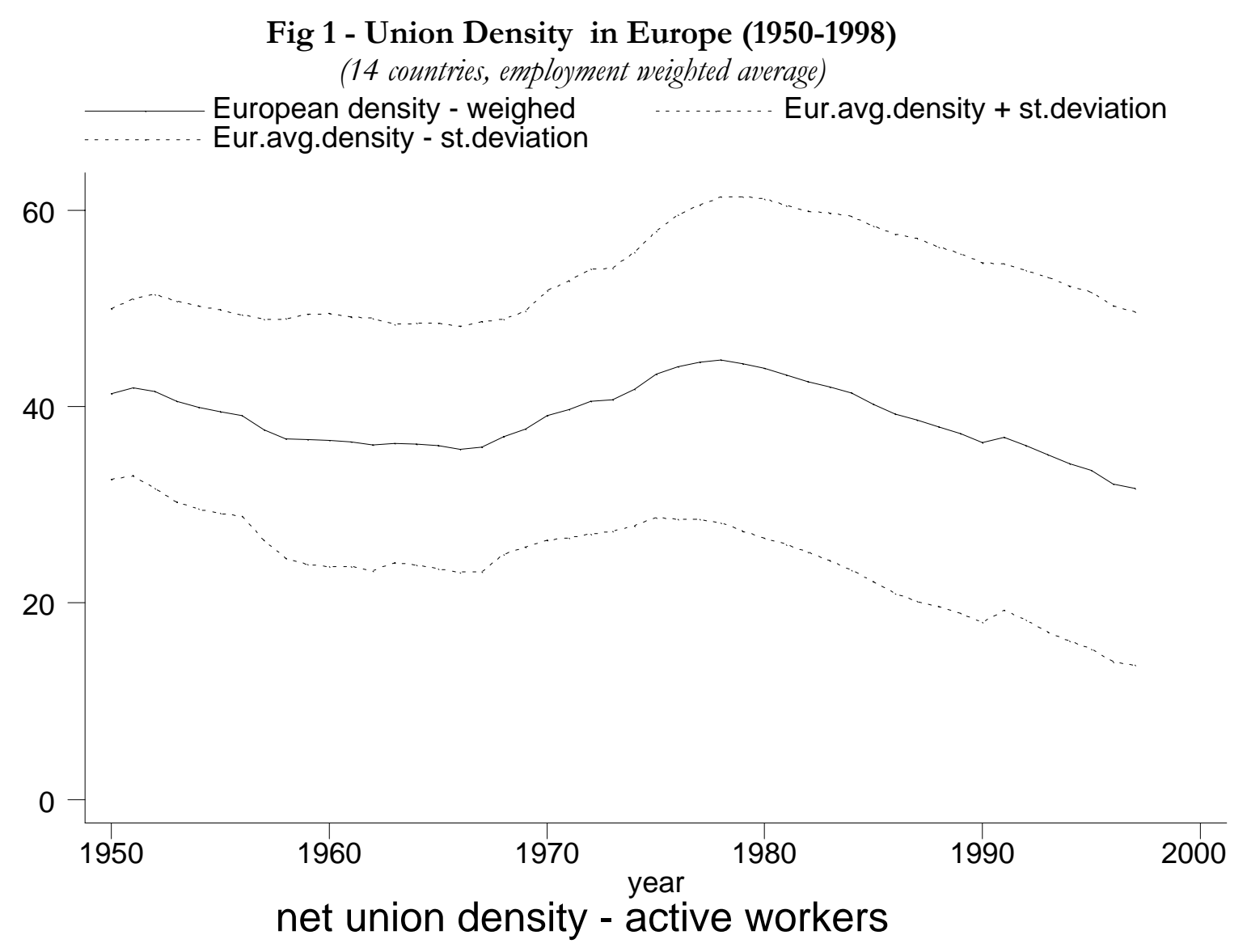

To highlight different patterns in European countries, in figure 2 we report the evolution separately by country. Levels and evolutions are quite different across countries, but the pattern of increasing unionisation in the 1970s followed by gradual decline is common to all. The differences in long run growth rates in some cases are substantial. As shown in table 2, most Nordic countries (Finland, Sweden and Denmark) experienced in the post-war period a rapid increase in unionisation rates, while the opposite occurred in some other countries in continental Europe (France, Netherlands and Austria). A common feature shared by most countries is the high-density rate observed in the public services.

\footnotetext{
${ }^{21}$ We tested the existence of different growth rates across the three periods $(1950-65,1966-80,1981-98)$ by running a simple regression in first differences with period dummies and testing the null of similar coefficients within periods. We could not reject the hypothesis at the 5 percent level for the first two periods and at the 10 percent level for the last period.

22 As measure of variability we computed the standard deviation of country unionisation rates over the sample period. The inclusion of Spain in the last decade the sample period partly contributes to the observed increase in dispersion. However, the exclusion of Spain from the sample reduces only marginally (less than 5 percent) the standard deviation of unionisation rates. The turning point at the end of the 70's is mainly attributable to Italy and Great Britain union density: see figure A.3.1.
} 
Fig 2 - Evolution of Net Union Density in Europe (1950-1998)

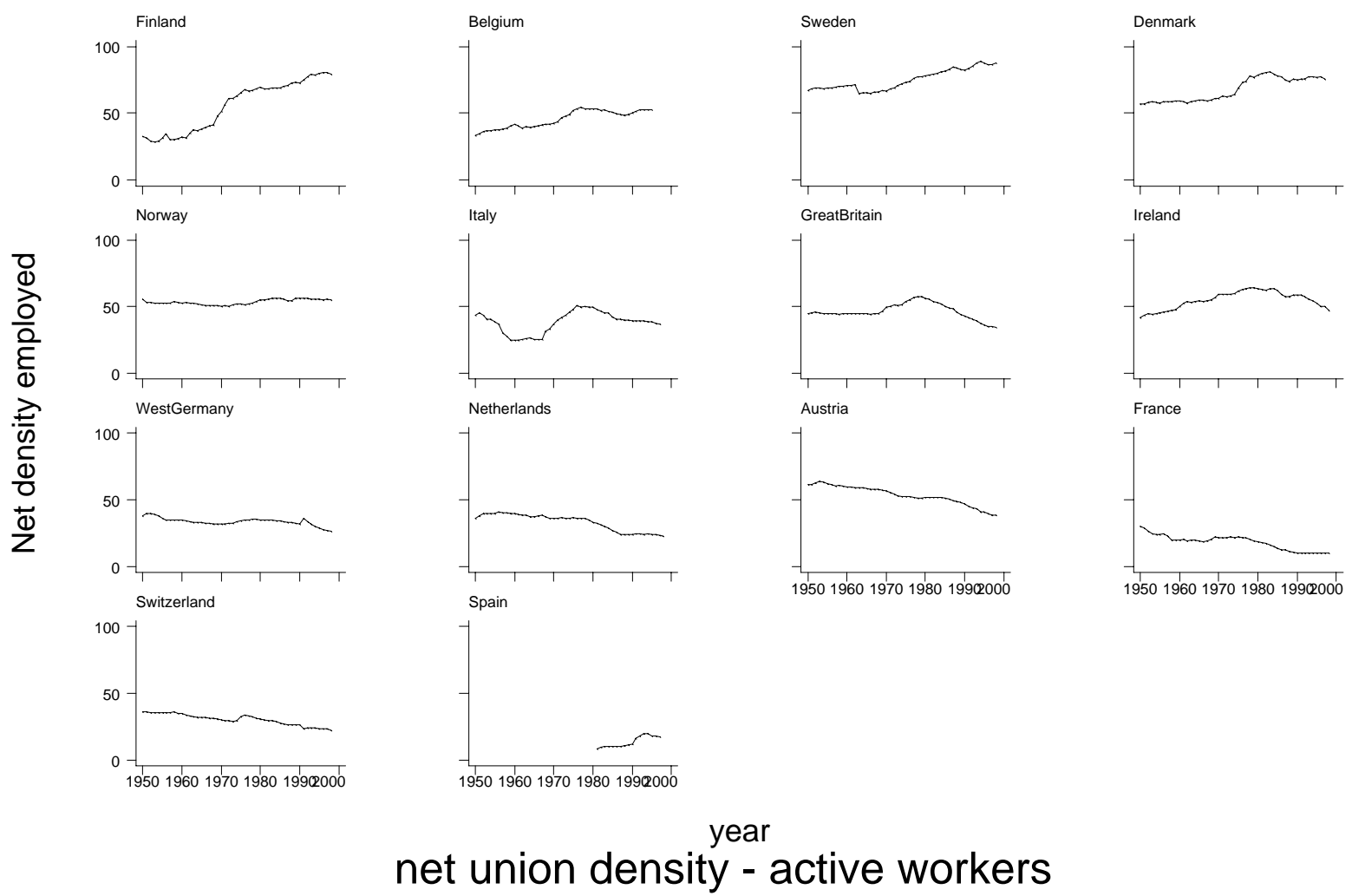

Table 2 - Net Union Density rates

\begin{tabular}{|c|c|c|c|c|c|}
\hline & $1960-65$ & $1975-80$ & $1990-95$ & $\begin{array}{c}\text { difference } \\
(9095- \\
6065)\end{array}$ & $\begin{array}{c}\text { density } \\
\text { rate in } \\
\text { public } \\
\text { services } \\
(1995)\end{array}$ \\
\hline Finland & 32.5 & 57.7 & 74.0 & 41.5 & n.a. \\
\hline Denmark & 58.4 & 66.9 & 77.2 & 18.8 & n.a. \\
\hline Sweden & 68.7 & 71.1 & 83.9 & 15.3 & 60.0 \\
\hline Belgium & 38.1 & 47.7 & 51.2 & 13.1 & 47.8 \\
\hline Ireland & 48.1 & 59.7 & 57.3 & 9.3 & n.a. \\
\hline Italy & 32.7 & 41.4 & 41.0 & 8.2 & 52.1 \\
\hline Norway & 52.8 & 51.7 & 55.5 & 2.7 & 88.3 \\
\hline Great Britain & 44.8 & 51.3 & 44.2 & -0.6 & $88.3^{*}$ \\
\hline (West) Germany & 35.8 & 33.5 & 32.3 & -3.6 & 84.2 \\
\hline Switzerland & 34.6 & 31.0 & 25.9 & -8.7 & 56.7 \\
\hline France & 22.8 & 20.8 & 12.2 & -10.6 & $17.5^{* *}$ \\
\hline Netherlands & 39.2 & 36.3 & 25.9 & -13.3 & $64.9 * *$ \\
\hline Austria & 60.8 & 54.3 & 46.4 & -14.4 & 99.6 \\
\hline Spain & -- & -- & 13.5 & -- & 36.2 \\
\hline
\end{tabular}

Note: * data refer to 1987 for selected branches - **data refer to 1993 for only some sectors

The differences in growth rates, however, have not substantially modified the ranking of countries according to their immediate post-war unionisation rates (the correlation between beginning and end of sample ranks is $\rho_{r k}=0.80$ ). If we compare union density rates across countries in the mid 1960s and the mid 1990s, as we do in figure 3, most countries lie near the $45^{\circ}$ line, thus suggesting that the structure of unionisation rates has remained relatively constant over time ${ }^{23}$. Along the $45^{\circ}$ line, the

${ }^{23}$ In figure 3, we report the estimated country-time fixed effects, obtained by regressing union density levels against country fixed effect interacted with a three time effect dummies (i.e. for the subperiods 50-65, 66-75, 76-95). Only extreme point are reported in the figure to reflect unionisation rates by countries between 1950-65 and 1976-95. 
countries featuring the most different permanent unionisation France and Sweden, while Finland and Austria have experienced the largest changes in union density (moving, respectively, from the $5^{\text {th }}$ to the $12^{\text {th }}$ and from the $12^{\text {th }}$ to the $8^{\text {th }}$ position in the ranking).

\section{Fig 3 - Union Density patterns in Europe (1950-65 versus 1976-98)}

den fixed effect 1975-98 $\quad 45^{\circ}$ line

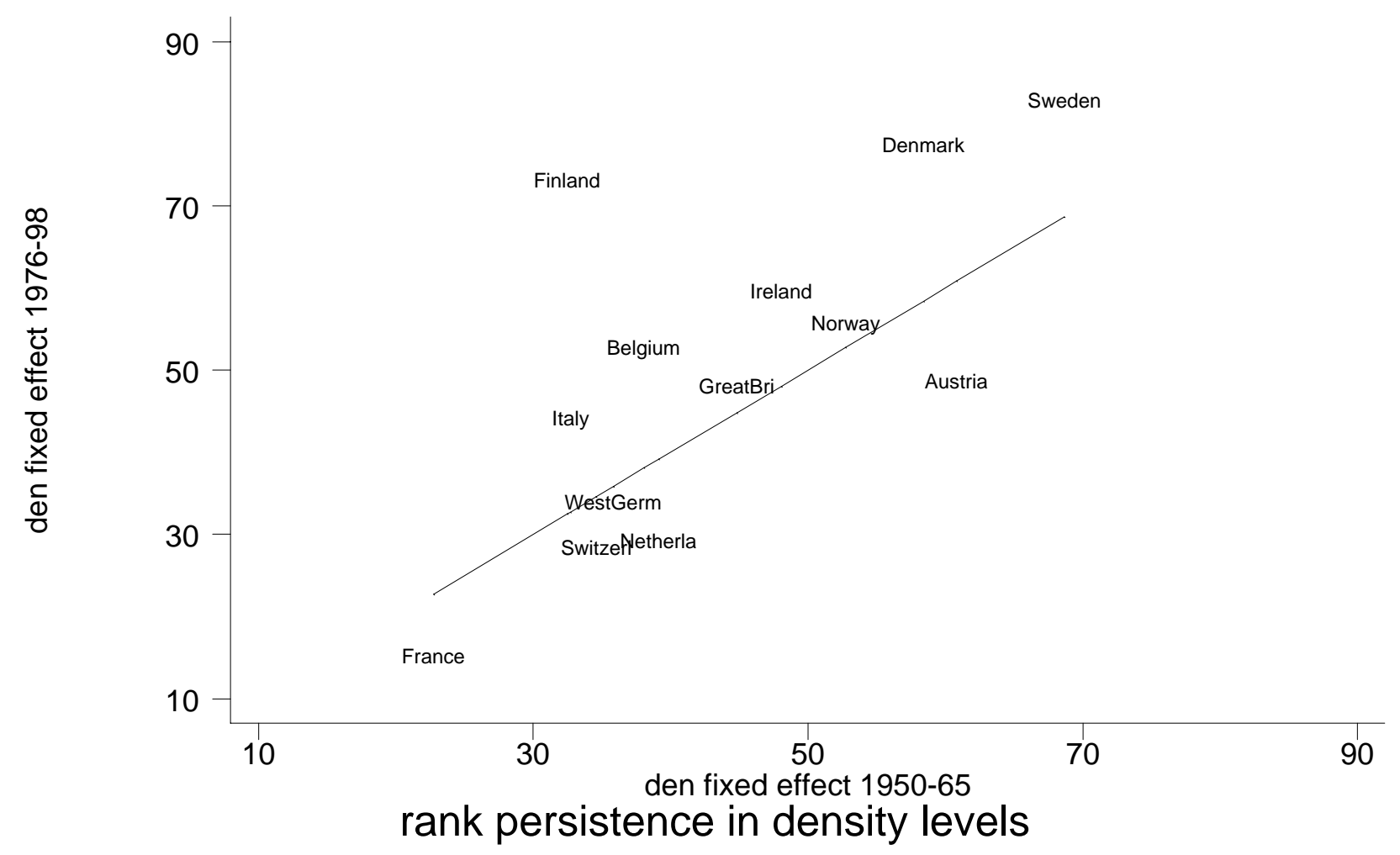

While some common shocks can explain the common trends over time, the heterogeneity of individual country experience both in the levels and in the long run trends of unionisation calls for an explanation. The theories reviewed above suggest that unemployment and inflation rates may explain unionisation patterns. As a first step, we explore the patterns in terms of country-specific and time-specific effects in unionisation and further investigate the behaviour of the residual component. As shown in (1) below, we regress union density, unemployment and inflation rates on country and time effects,

$$
x_{i t}=C_{i}+T_{t}+\varepsilon_{i t}
$$

where $x_{i t}$ stands for any of the variables considered (union density, unemployment or inflation rates), where $i$ indicates the $i$-th country in period $t, C$ is a country fixed effect and $T$ is a common time effect, finally $\varepsilon_{i t}$ is the residual term. This decomposition allows us to get a general idea of the general patterns of unionisation in Europe, under the maintained assumption of time invariant country effects and common time effects. As an example take two countries, Finland and France: estimating equation (1) we find that the country effect are, respectively, 54 and 16 percent, while the (common) time effect for 1990-95 period is 2.8 percent. Hence the predicted unionisation rates, for the final period, are 56.8 and 18.8 percent, respectively for Finland and France. Comparing the predicted with the actual rates (76.2 for Finland and 10.2 for France, in 1990-95) we find that union density was 19.7 percentage point above to what would have implied a "common" behaviour in Europe, while France was 8.6 percent below. How can we explain this residual? In other words, can the exceptionally low (high) unionisation rates observed in France (Finland), as opposed to the pattern predicted by our simple model, be explained by equally low (high) patterns in unemployment or inflation? Estimating equations in the 
form (1) for unemployment and inflation rates, we can plot in figures 4 and 5 union density deviations against unemployment and inflation deviations (from countries- and time-effect estimates).

A positive relationship is apparent in both figures 4 and 5 , and provides some support to the idea that unexpected economic shocks (in unemployment and/or inflation) have affected demand for union protection. ${ }^{24}$ The pairwise relationship between unionisation and unemployment residuals is strong and significant (if weaker if Finland is excluded from the sample); it is positive, but only weakly significant, between unionisation and inflation residuals. ${ }^{25}$ To give a more direct intuition of the economic implication of this (linear) trade-off consider that an increase in one percentage points in inflation determines a two third increase in union density. Obviously, these exercises only aim at providing some descriptive evidence on correlations between variables leaving open the issue of the direction of causality ${ }^{26}$.

It is also evident that there is much more to be explained in terms of the evolution of union density across countries than a simple decomposition can achieve ${ }^{27}$. Furthermore, the exercise seem to suggest that the explanatory contribution of economic shocks, affecting individual's decision to join the unions is only marginal and that there ought to be other factors which are potentially relevant to explain both the differences across countries and over time. In Appendix 3 we report information about existing measures for labour market institutions and we repeat the same exercise for each measure (see figure A.3.2 in Appendix 3). There is statistically significant evidence of positive correlation of union density with benefit replacement rate, mandatory extension, Kaitz index, workplace presence and tax wedge, and negative correlation with wage indexation. However, as Belot and van Ours (2000) have forcibly pointed out, it is the combination of institutions that matters for labour market performance, and therefore we have to resort to multivariate analysis.

Ideally, we would have liked to account also for wage compression effects, however, a number of important limitations prevented us to formally include wage compression among our explanatory variables. First, data availability is limited to recent years; second, the direction of causation is not straightforward and reverse causation should be a main concern. We did explore the issue experimenting with available data -- i.e. looking at correlations and fitting regressions using data for restricted periods (see figure A.3.3 in Appendix 3) - which seem to suggest that union density is negatively related to wage inequality at both ends of the earnings distribution. This provides additional support to the hypothesis that unions aim at reducing wage dispersion and particularly so for low wage workers.

\footnotetext{
${ }^{24}$ In both graphs Finland's residuals are significantly dispersed. The latter can be probably be attributed to the critical economic circumstances that occurred in the aftermath of the "fall of the Berlin Wall". The profound restructuring process that occurred in Finland and in most Eastern European countries had a major impact on the structure of these economies, which is unlikely to be explained by our simple dummy variables specification.

25 The estimated coefficients of regression lines reported in figures 4 and 5 are obtained from a univariate regressions of union density residuals on unemployment residuals is 0.68 with a t-stat of 2.42. Conversely the coefficient from a regression of union density residuals on inflation residuals is 0.677 with a t-stat of 1.77 .

${ }^{26}$ Empirical evidence on reverse regressions suggest a similar picture, that is a regression of unemployment residuals on union density residuals shows a coefficient of 0.061 (2.42), while inflation residuals show a coefficient of 0.061 (1.77).

${ }^{27}$ We also estimated an alternative specification where country-specific effects $(C)$ were also interacted with a time trend (trend): $x_{i t}=C_{i}+C_{i} \cdot$ trend $_{t}+\varepsilon_{i t}$ where $C_{i}$ is a country fixed effect and $C_{i} \cdot$ trend $_{t}$ is a country-specific trend. In this way, unionisation patterns can be decomposed in country-specific "levels" and "trends". The estimated country-specific trends in union density reveal a significant heterogeneity across country. Moreover, simple pairwise correlations between estimated country-specific trends in union density, respectively, with unemployment $\left(\rho_{\text {den,une }}=0.04\right)$ and inflation $\left(\rho_{\text {den,inf }}=0.21\right)$ show low correlations and statistically insignificant coefficients. In other words, it seems that long run trends in unemployment and inflation have little explanatory power on unionisation patterns.
} 
Fig 4 - Union density and unemployment in Europe union density Fitted values

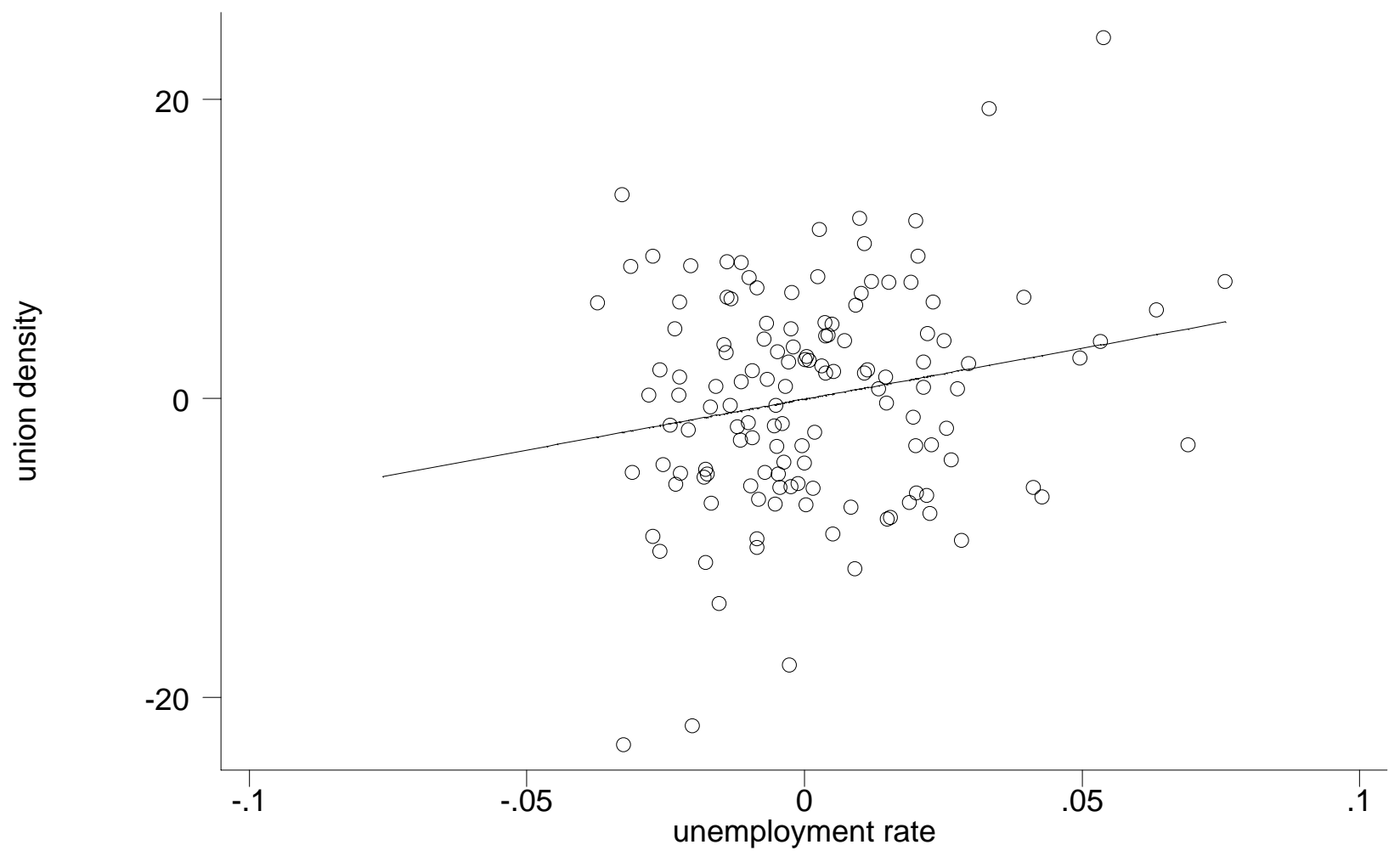

Fig 5 - Union density and inflation in Europe union density Fitted values

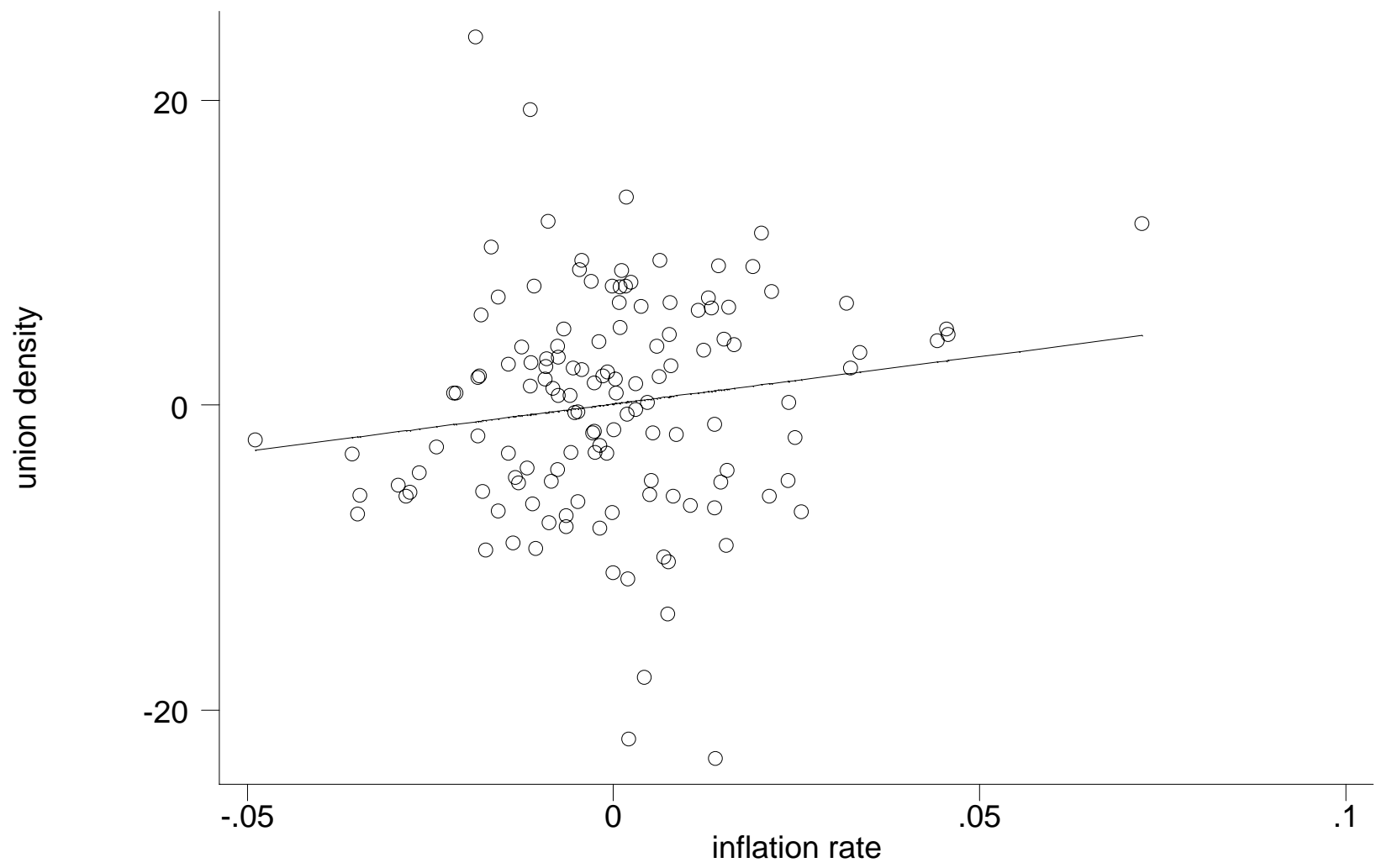




\subsection{Available data}

In table 3 we report descriptive statistics for the entire data-set. (A more detailed description of data sources is reported in Appendix 2, and country means are reported in Appendix 3.) Our union variable is the density rate among active workers. We account for compositional effects in the workforce controlling for the share of Male, Manual workers in the Manufacturing sector (the so-called triple " $\mathrm{M}$ " workers, who are the typical union members in a fordist society). Economic shocks are captured by inflation and unemployment rates. Other variables account for the main features characterising the labour market institutional setting, namely: replacement rates and duration of unemployment benefits, employment protection measures, minimum wage and tax wedge. Further indicators of the environment in which unions operate are mandatory extension of collective agreement, workplace representation, centralisation of bargaining and multiple-union competition. Information on union dues would be very relevant, but no data are available. The significance of strike activity is less than fully clear: it can represent commitment to be a union member, alternatively it can measure the relevance of a social custom - as way to conform to a behavioural norm (Checchi and Corneo 2000) -, or be an indirect measure of the degree of social conflict and management opposition. Product market rents are proxied by several variables: share of public sector employment, indicators of market regulation, degree of openness to international trade, wage share on the gross domestic product. Finally, the share of left voting in general elections captures the political orientation of the government.

Given the emphasis placed on the long-term determinants of unionism, to remove excessive cyclical fluctuation in economic variables and in order to match relevant institutional data, the variables have been averaged over five-year periods. Most of the institutional variables are only available from the 60's, and therefore we shall restrict our sample period to 1960 to 1998, thus implying 8 observation per country. Since unionisation data for Spain are available only from 1981 onwards, the country has been excluded from the empirical analysis, though included in the descriptive analysis.

\section{Table 3 - Net Union Density rates}

(14 countries - unweighed averages)

\begin{tabular}{|c|c|c|c|c|c|c|}
\hline variable definition & var name & obs & mean & sd.dev & $\min$ & $\max$ \\
\hline union (net) density rate for active dependent employment & DEN & 649 & 45.77 & 17.69 & 8.30 & 88.60 \\
\hline share of male dependent employment in industry on total employment & MMM & 668 & 0.25 & 0.07 & 0.02 & 0.41 \\
\hline unemployment rate & UNE & 686 & 0.07 & 0.05 & 0.00 & 0.25 \\
\hline inflation rate (yearly change) in consumer price index & INFL & 686 & 0.05 & 0.04 & -0.05 & 0.28 \\
\hline unemplo & BRR & 504 & 0.40 & 0.21 & 0.00 & 0.88 \\
\hline inde & $\mathrm{BD}$ & 504 & 0.40 & 0.31 & 0.00 & 1.00 \\
\hline & EP & 504 & 1.13 & 0.56 & 0.00 & 2.00 \\
\hline index & CENTR & 659 & 0.35 & 0.21 & 0.06 & 0.74 \\
\hline (i.e. union administered unemployment benefit) & GHENT & 686 & 0.28 & 0.45 & 0.00 & 1.00 \\
\hline ( & TW & 495 & 0.50 & 0.12 & 0.17 & 0.83 \\
\hline representation & WORK & 655 & 0.63 & 0.29 & 0.20 & 1.00 \\
\hline Kaitz & KAITZ & 686 & 0.54 & 0.10 & 0.32 & 0.71 \\
\hline man & MANDAT & 686 & 0.76 & 0.24 & 0.18 & 1.00 \\
\hline pendent employment & PA & 629 & 0.19 & 0.07 & 0.07 & 0.37 \\
\hline $\mathrm{T}$ & MKREG & 686 & 1.56 & 0.48 & 0.50 & 2.30 \\
\hline & MKREGD & 686 & 5.00 & 0.74 & 1.00 & 6.00 \\
\hline Herfin & HERF & 582 & 0.62 & 0.24 & 0.21 & 1.00 \\
\hline trade (export+import/gdp) & OPEN & 476 & 0.67 & 0.27 & 0.22 & 1.56 \\
\hline ate sector) & WAGESH & 406 & 0.57 & 0.07 & 0.39 & 0.77 \\
\hline & LEFTV & 597 & 0.39 & 0.09 & 0.12 & 0.56 \\
\hline workers involved in strike on dependent employment & STRIKE & 615 & 0.07 & 0.14 & 0.00 & 1.00 \\
\hline
\end{tabular}

Note: variable names as reported in tables in the appendices. Self explanatory names have been used in the tables reported in the main text. 


\section{Empirical analysis of the determinants of unionism}

\subsection{The Empirical Model}

In this section we sketch the main features of the empirical analysis and discuss the main set of results. We assume that observed unionisation rates are determined both by economic factors, as well as by institutional arrangements. Economic circumstances may affect the desire of workers to be insured against labour market risks by unions or to share rents through collective bargaining, while labour or product market regulations and welfare provisions may alter unionisation patterns by either favouring or providing suitable alternatives to union activity. We focus on union density as an indicator of unionisation. Denoting with $S_{i t}$ as union density in the $i$-th country at time $t$, we run regressions in the form

$$
S_{i t}=\varphi\left(X_{i t}, R_{i t}, \mu_{i}, \lambda_{t}\right)
$$

where $X_{i t}$ is a vector of economic factors that can affect unionisation rates, $R_{i t}$ a (country-specific, time-varying) set of institutional features, and $\mu_{i}$ and $\lambda_{t}$ country and time fixed effects. The specification of equation (2) with the unemployment rate in the $X_{i t}$ vector can be thought of as one of the structural equations to be estimated in order to assess the impact of (endogenous) union density on unemployment. The standard literature on the effect of unions on economic performance usually focuses on a specification with the total (or long term) unemployment as a dependent variable and union density (as well as coverage and other unionisation indicators) on the right-hand-side, considering the latter exogenously determined (Nickell, 1997 and 1999; Blanchard and Wolfers, 2000). As it is argued in the paper, it might as well be interesting to reverse the standard order of causation and investigate the impact of economic factors on union density ${ }^{28}$.

In particular, our specifications include the following variables: a proxy for compositional effects (i.e. demographic, industry and other structural employment features), economic shocks (i.e. inflation, unemployment and product market rents) and various institutional arrangements (i.e. employment protection, unemployment benefits, structure of collective contracts, indexation clauses, local workplace representatives, mandatory extension of collective contracts, minimum wages, tax wedge, product market regulation and public employment).

In the standard framework, the evolution of union density - net of composition effects and controlling for country and time fixed effects - should be entirely explained by countries' long run economic factors and there should be no (residual) role for institutional factors to play. But union density rates can also depend on whether labour market institutions are more or less union "friendly". Hence, we proceed in two steps. First, we run basic specifications that include controls for composition effects and economic factors. Next, we introduce our set of institutional variables, initially as time invariant (as it is often done in the literature) and also as time varying components (to capture for relevant changes occurred over time). When the specification allows it, we also include specific time dummies and country fixed effects. In order to improve the efficiency of the estimates, we use generalised least squares (GLS) methods both using a robust estimator (Huber-White procedure) as well as allowing correlation of errors within countries (but independence across countries) ${ }^{29}$. It should be noted right at the start, that the real test for the relevance of institutions to explain unionisation patterns in Europe is in terms of the evolution over time of country's specific institutional feature, which is what we do in our final step where we estimate a full fledged model with both country-specific economic and

\footnotetext{
${ }^{28}$ We also estimated the unemployment and union density equations jointly using a set of instrument (worker representation rights and lagged unemployment rates. When endogeneity of union density in an unemployment equation is appropriately accounted for the estimated coefficient shows ......????. We are particularly grateful to Ian Van Ours for suggesting to us this extension.

${ }^{29}$ In practice, we use alternatively the "robust" and the "cluster" options in Stata 7.0.
} 
institutional (time varying) factors, as well as the relevant interactions among them. Of course, controlling for both time and country fixed effects in the latter model asks a lot of available data ${ }^{30}$.

Finally, a word of caution before interpreting the results is in order. We investigate the impact of macroeconomic shocks and institutional arrangements on unionisation patterns, but union density may in turn affect unemployment and inflation, as well as some of the institutional variables. While a priori it is not evident why the causation should go in that direction - as maintained by most studies on the effect of institutions (Nickell 1999; Blanchard and Wolfers 2000; Bertola, Blau and Kahn 2001) - we are aware of the potential endogeneity problems that may affect our estimates. Given the lack of appropriate instrument and the restricted degrees of freedom available, in the forthcoming analysis we prefer to stick to simple OLS estimate, even if some of the parameters could be biased downward.

\subsection{Unionisation, economic shocks and institutions: main results}

\subsubsection{A model with pure economic factors}

We begin by investigating the impact of economic factors on their own, controlling for compositional factors (here proxied by the employment share attributable to men employed in manufacturing, who are commonly thought to be the "core" of union membership), relegating to the country fixed effects and to the common time effects the role played by institutional forces. For sake of space, we discuss herein the main results of the specifications with only economic factors while relegating the actual estimates to the Appendix (see table A7) ${ }^{31}$. In general equations include a constant, compositional factors, dummies to account for changes in the definition of the dependent variable (in selected countries and time periods), country fixed effects and in some cases also for (common) time effects (see columns 3, 5 and 6$)^{32}$. In order to address the potential endogeneity of unemployment rates, we also estimate a model where unemployment is a (lagged) predetermined variable (see column 2). In general results seem not to be significantly affected by the introduction of lagged unemployment, while the coefficient itself is smaller and statistically insignificant. Also, given the choice of focussing on long run relationship by using quinquennial averages, it is not immediate to interpret what a five year lag in unemployment might mean; hence, in the rest of the analysis we restrict our attention to the current unemployment rate.

In all estimated equations, compositional effects are insignificant, and are likely absorbed by country fixed effects. On the contrary, both unemployment and inflation show a positive impact on unionisation. While reverse causation cannot be completely ruled out, the estimated are consistent with increasing union density in the face of adverse shocks to workers' welfare - as measured by inflation and unemployment rates. ${ }^{33}$ Part of the effect of unemployment level as a proxy of the risk of job loss can be captured by a 3-year moving standard deviation of the unemployment rate (the $\mathrm{SD}_{\text {une }}$ variable), which is positively significant when considered in alternative to unemployment rate. The estimated coefficient on inflation suggests a strong and statistically significant impact on union density rates: an increase of one percent in inflation rate commands an almost equal increase in density rates ${ }^{34}$. Inflation

\footnotetext{
30 To the extent that time fixed effects pick some general trends in unemployment and inflation, the impact of these variables on union density is likely to be underestimated.

31 We constructed a logistic transformation for the union density rate to account for the potential boundedness of the variable between 0 and 1 . Since in both cases results were hardly affected, in the tables we report standard OLS estimates for the level of density.

32 Given the relevance of cross-country differences in union density rates (in levels), when country fixed effects are excluded the explicative power of the model drops significantly $\left(\mathrm{R}^{2}(\operatorname{adj})=0.09\right)$.

33 On British data Booth 1983 and Carruth and Disney 1988 find a negative impact of unemployment rates whereas Freeman and Pelletier 1990 find a positive one for the same country. A positive sign for the unemployment rate is also found for Finland (Pehkonen and Tanninen 1997) and for West Germany in the long-term (Carruth and Schnabel 1990), whereas a negative sign is obtained for Italy (Checchi and Corneo 2000, via the definition of worker surplus).
}

34 The estimated coefficient is, however, statistically different from one in most equations. 
variability (3-year moving standard deviation of the inflation rate - the $\mathrm{SD}_{\text {infl }}$ variable) is found to be not statistically significant. In order to capture the relevance of a more complex relationship between unemployment and inflation (as opposed to the linear one implied by the so-called "misery index" - see Okun 1981, Bruno and Sachs 1985), ${ }^{35}$ we also experimented an interaction term which never turned to be significant.

On the whole it appears that economic shocks, affecting both employment probability and purchasing power of wages, raise the demand for unionism after controlling for country characteristics. We now turn to a detailed analysis of such country specificities.

\subsubsection{The Impact of Institutions}

The above results highlight the potentially relevant but rather limited role of economic factors in explaining the evolution of unionisation as well as cross country differences in Europe. To account for, and better interpret, the substantial variation captured by (unobserved) country fixed effects in the previous estimations, we initially replaced country fixed effect with (time invariant) measures of institutions. While this imposes that all (time invariant) differences in union density be accounted by differences in institutions, it also implicitly assume that no major changes have occurred in the institutional setting over the period considered. Since treating institutions as time invariant country attributes is excessively reductive - for the institutional setting has experienced significant changes over the time period considered - we will not place too much emphasis on these estimates. In practice, as time invariant institutions we have used the country mean value of each variable over the time period considered. There is, however, an advantage in doing so as for some important institutional arrangements no time varying information is currently available in a comparable way.

The main findings (results are not reported here, see table A.4.1 in Appendix 4) suggest that to the extent that institutional arrangements reinforce the role and the bargaining power of unions on the labour market (i.e. wage floor levels, workplace representation, functions in administering benefits and centralisation in bargaining) their impact is likely to be positive; conversely when the effect of the institution weakens the relevance of the services offered by the unions (i.e. duration and coverage of benefits, wage indexation clauses, employment protection measures and mandatory extension of collective contracts) the impact is expected to be negative. We first estimated a simple model with time effect and institutions and then we add time varying economic variables. ${ }^{36}$

When we abstract from economic and compositional effects (only captured in their common trends by time dummies), labour market institutions can be divided into two groups. On one side, some institutional features raise union density, and can therefore be labelled as "complementary institutions", since they favour union activity, either by reinforcing bargaining power or by raising the net benefit of unionisation: minimum wages (as measured by the Kaitz index), workers representation rights, 'Ghent' administrative system of insurance schemes (providing unemployment benefit to union members only) and centralisation of collective bargaining.

Conversely, a negative impact on union density rates is found on the duration of unemployment benefits, employment protection legislation, indexation clauses, mandatory extension of collective contracts. The above institutions seem to be perceived by workers as a substitute for union income and job-insurance activity, and therefore we will label these institutions as "substitute institutions". In general these results are unchanged when country-specific economic factors are introduced, the statistical significance of the latter however falls when also common time effects are considered. The same classification carry over almost unchanged when time varying measures of institutions are allowed to replace time invariant ones.

\footnotetext{
35 The so-called 'misery index' captures adverse shifts (outwards) in the inflation-unemployment trade-off (or Phillips curve).

36 The model with simple common time dummies should also give some insight on the problems associated to the potential endogeneity of the unemployment rate. As result show, parameter estimates do not change dramatically when unemployment is added to the model (columns 2 and 3 in table A.4.1), suggesting that the estimated effects should not be significantly altered. We also experimented a large set of interactions. In general, interaction terms bear the same sign of the institutional variable - when entered on its own - thus reinforcing the effect.
} 
There are however some institutional variables that do not conform to our theoretical expectations (table A.4.1 in Appendix 4). An example is the unemployment replacement rate, which we would expect to figure among the "substitute" institutions, on the ground that the higher replacement rate of the benefit, the lower is the value attached to union protection. The time invariant measure for this variable changes sign and is often non significant. Also the tax wedge variable does not conform to our expectations. Since labour taxes are less distortionary in more centralised (i.e. more unionised) labour markets, we would anticipate a positive association with union density (Summers et al. 1993). This is the effect we find when time varying measures are considered, whereas for time invariant values a negative and statistically significant correlation emerges. ${ }^{37}$

Finally, as far as the "bad view" of unions, as coalition of rent-seekers, is concerned we find some support in the data. The share of public employment is positively associated with union density (for the lower managerial opposition and ease of securing public rents), and also product market regulation in the private sector works in the same direction. Ideally the more regulated (and/or closed to foreign competition) is the internal market, the higher are firms' rents and the stronger are the incentive to join a union in order to obtain a larger share of these rents (Blanchard and Giavazzi 2001). While the proxy for market regulation is positively correlated with union density, the degree of openness seem to point more in the direction of protection from external risk showing a negative and statistically significant sign.

\subsubsection{Changing institutions and interactions}

To accommodate the changes that the institutional setting has undergone over the post-war period, when information is available, we allow for institutional variables to change over time. Tables 4 reports the main set of results. In addition to a constant and dummies to account for changes in the definition of the dependent variable, all estimated equations control for time dummies and - when only time varying institutions are included - also country dummies. In this context, the effect of the variables should be interpreted as the impact of within country changes. When we investigated the effects of the Kaitz index and mandatory extension of collective contracts - for which we do not have time varying information - country dummies have been excluded (see columns 2, 4 and 6). Without country fixed effects - and to the extent that the time invariant institutions included cannot fully account for time invariant observed (and unobserved attributes) - estimates pick up also some cross-country variation and thus might be interpreted differently. Of course, the two way fixed effect specification chosen - and reported in table 4 in columns 1, 3 and 5 - represents the hardest test for our empirical model.

Our composition factor - i.e. the 'male, manual, manufacturing' share in the employee workforce - has positive impact on unionism, indicating that demographic and structural changes in the workforce may have played a relevant role in unionisation patterns. Both economic factors - unemployment and inflation - appear less robust once compositional effects, time varying institutions and country and time dummies are included.

Coming to the role of institutions, we find that benefit duration (and in some cases also the benefit replacement rate) have a strong negative impact on unionisation. Similarly, employment protection regulation, indexation clauses and mandatory extension provision, all report a negative impact thus confirming a 'substitute' role for union activities. Conversely, the presence of workers representation rights, responsibilities in administering benefits, the existence of a wage floor and large tax wedge all

\footnotetext{
37 The effect can be ambiguous as opposing forces can be at work: on the one hand, the effect of the wedge by raising the cost of labour may negatively affect employment and ultimately unionisation rates; alternatively, workers' fear that employers may pass onto wages the effect of taxes may induce workers to join the union to seek protection against wage cuts (Daveri and Tabellini, 2000). In this light we expect, the compositional effect (i.e. the between effect) of the tax wedge to show up when time invariant institution are considered, while the incentive effect to join the union to dominate in time varying fixed effects regression (i.e. the within effect).
} 
contribute to the rise of unions, thus validating a 'complementary' role for unions. Amongst the latter group the centralisation variable is sometimes wrongly signed and statistically insignificant. However, in the last two columns we introduce an alternative measure for union organisational set-up. If the success of union organisational activity also depends on the existence of economies of scale and lack of fragmentation across different trade unions, an index proxying for inter-union competition should exert a negative impact. Coherently with this theoretical expectation, the Herfindahl index computed on membership shares indicates that the more fragmented is the membership across competing unions, the lower is total membership.

The specifications reported in columns 5 and 6 of table 5 explore the empirical relevance of the "bad" view. A protected, highly regulated sector where unions can extract rents at little (or no) employment cost, proxied by the share of public sector employment, shows a strong and statistically significant impact on union density. This indicates that the success of the unions indeed requires both economic rents and reduced product market competition - with the public sector offering an extreme example. Other variables proxying for product market regulation in the private sector and external competitiveness do not perform as well showing a different sign, as compared to theoretical expectations, and in some specifications, lack of statistical significance. In interpreting the openness variable, however, it cannot be excluded that the dominating effect is the risk-reducing role played by the unions (Rodrik, 1998). We also experimented with the wage share in value added, which also exhibits an odd sign. Even abstracting from labour market institutions and focussing exclusively onto variables accounting for the "bad" view of unions (as we do in column 5), those variables are statistically insignificant. 
Table 4 - Union Density, Economic Shocks and Time Varying Institutions

13 countries $-1960-2000$

\begin{tabular}{|c|c|c|c|c|c|c|}
\hline Model : & 1 & 2 & 3 & 4 & 5 & 6 \\
\hline \multicolumn{7}{|l|}{ Institutions } \\
\hline $\begin{array}{l}\text { ben.replac. } \\
\text { ratio }\end{array}$ & $\begin{array}{c}0.008 \\
(0.15)\end{array}$ & $\begin{array}{r}0.063 \\
(1.14)\end{array}$ & $\begin{array}{l}-\odot .042 \\
(-\odot .95)\end{array}$ & $\begin{array}{l}-0.088 \\
(-1.81)\end{array}$ & & $\begin{array}{l}-0.006 \\
(-0.11)\end{array}$ \\
\hline ben.durat. & $\begin{array}{l}-0.177 \\
(-4.89)\end{array}$ & $\begin{array}{l}-0.189 \\
(-4.14)\end{array}$ & $\begin{array}{l}-0.112 \\
(-2.88)\end{array}$ & $\begin{array}{l}-0.187 \\
(-4.27)\end{array}$ & & $\begin{array}{l}-0.244 \\
(-7.46)\end{array}$ \\
\hline empl.prot. & $\begin{array}{l}-\odot .088 \\
(-2.85)\end{array}$ & $\begin{array}{l}-0.179 \\
(-6.62)\end{array}$ & $\begin{array}{l}-\odot .088 \\
(-3.42)\end{array}$ & $\begin{array}{l}-0.104 \\
(-3.28)\end{array}$ & & $\begin{array}{l}-0.092 \\
(-3.85)\end{array}$ \\
\hline $\begin{array}{l}\text { bargaining } \\
\text { centr/coord( }\end{array}$ & $\begin{array}{l}-0.123 \\
(-1.66)\end{array}$ & $\begin{array}{r}0.209 \\
(3.81)\end{array}$ & $\begin{array}{l}-0.092 \\
(-1.53)\end{array}$ & $\begin{array}{r}0.201 \\
(3.95)\end{array}$ & & $\begin{array}{l}-\odot .023 \\
(-\odot .36)\end{array}$ \\
\hline $\begin{array}{l}\text { wage } \\
\text { indexation }\end{array}$ & $\begin{array}{l}-0.050 \\
(-2.19)\end{array}$ & $\begin{array}{l}-0.033 \\
(-1.27)\end{array}$ & $\begin{array}{l}-0.034 \\
(-1.61)\end{array}$ & $\begin{array}{l}-0.055 \\
(-2.60)\end{array}$ & & $\begin{array}{l}-\odot .067 \\
(-3.75)\end{array}$ \\
\hline $\begin{array}{l}\text { workplace } \\
\text { represent. }\end{array}$ & $\begin{array}{r}0.240 \\
(3.72)\end{array}$ & $\begin{array}{r}0.355 \\
(8.99)\end{array}$ & $\begin{array}{r}0.187 \\
(4.05)\end{array}$ & $\begin{array}{r}0.222 \\
(4.09)\end{array}$ & & $\begin{array}{r}0.170 \\
(3.17)\end{array}$ \\
\hline tax wedge & $\begin{array}{r}0.641 \\
(4.14)\end{array}$ & $\begin{array}{r}0.394 \\
(2.91)\end{array}$ & $\begin{array}{r}0.425 \\
(3.03)\end{array}$ & $\begin{array}{r}0.366 \\
(3.68)\end{array}$ & & $\begin{array}{r}0.416 \\
(4.35)\end{array}$ \\
\hline ghent system & & $\begin{array}{r}0.177 \\
(8.35)\end{array}$ & & $\begin{array}{r}0.226 \\
(8.97)\end{array}$ & & $\begin{array}{r}0.290 \\
(10.42)\end{array}$ \\
\hline kaitz index & & $\begin{array}{r}1.324 \\
(4.94)\end{array}$ & & $\begin{array}{r}2.045 \\
(8.10)\end{array}$ & & $\begin{array}{r}1.917 \\
(9.04)\end{array}$ \\
\hline $\begin{array}{l}\text { mandatory } \\
\text { ext. of cont }\end{array}$ & tr. & $\begin{array}{l}-0.464 \\
(-5.50)\end{array}$ & & $\begin{array}{l}-0.773 \\
(-7.85)\end{array}$ & & $\begin{array}{l}-0.606 \\
(-7.89)\end{array}$ \\
\hline $\begin{array}{l}\text { Market and c } \\
\text { public sect. } \\
\text { employm. }\end{array}$ & composit & 1 factor & $\begin{array}{r}1.213 \\
(4.90)\end{array}$ & $\begin{array}{r}1.191 \\
(4.74)\end{array}$ & $\begin{array}{r}1.832 \\
(6.80)\end{array}$ & $\begin{array}{r}0.812 \\
(4.26)\end{array}$ \\
\hline $\begin{array}{l}\text { prod.market } \\
\text { regulation }\end{array}$ & & & & & $\begin{array}{r}0.010 \\
(0.48)\end{array}$ & $\begin{array}{l}-0.037 \\
(-2.99)\end{array}$ \\
\hline trade openne & ess & & & & $\begin{array}{r}6.739 \\
(0.68)\end{array}$ & $\begin{array}{l}10.744 \\
(2.81)\end{array}$ \\
\hline $\begin{array}{l}\text { herfindhal } \\
\text { index (union }\end{array}$ & s) & & & & $\begin{array}{r}0.144 \\
(1.24)\end{array}$ & $\begin{array}{r}0.164 \\
(3.55)\end{array}$ \\
\hline unemployment & & & $\begin{array}{l}-0.212 \\
(-0.71)\end{array}$ & $\begin{array}{l}-1.194 \\
(-3.70)\end{array}$ & $\begin{array}{l}-0.047 \\
(-0.15)\end{array}$ & $\begin{array}{l}-0.927 \\
(-2.96)\end{array}$ \\
\hline inflation & & & $\begin{array}{r}0.539 \\
(2.13)\end{array}$ & $\begin{array}{r}-0.447 \\
(-1.17)\end{array}$ & $\begin{array}{r}0.779 \\
(3.12)\end{array}$ & $\begin{array}{r}0.121 \\
(0.38)\end{array}$ \\
\hline wage share & & & & & $\begin{array}{l}-0.309 \\
(-1.77)\end{array}$ & $\begin{array}{l}-\odot .03 \odot \\
(-\odot .21)\end{array}$ \\
\hline $\begin{array}{l}\text { male empl. } \\
\text { manufactur. }\end{array}$ & & & $\begin{array}{r}0.504 \\
(2.87)\end{array}$ & $\begin{array}{r}0.280 \\
(1.61)\end{array}$ & $\begin{array}{r}0.564 \\
(2.44)\end{array}$ & $\begin{array}{r}0.484 \\
(2.42)\end{array}$ \\
\hline Constant & Yes & Yes & Yes & Yes & Yes & Yes \\
\hline Change-def. & Yes & Yes & Yes & Yes & Yes & Yes \\
\hline Country dum. & - Yes & & Yes & & Yes & \\
\hline Year dum. & Yes & Yes & Yes & Yes & Yes & Yes \\
\hline $\begin{array}{l}\mathrm{R}^{2} \\
\mathrm{~N} \text {. obs : }\end{array}$ & $\begin{array}{c}0.939 \\
104\end{array}$ & $\begin{array}{c}0.839 \\
104\end{array}$ & $\begin{array}{c}0.964 \\
104\end{array}$ & $\begin{array}{c}\odot .899 \\
104\end{array}$ & $\begin{array}{c}0.948 \\
104\end{array}$ & $\begin{array}{c}0.929 \\
104\end{array}$ \\
\hline
\end{tabular}

notes: robust t-statistics in parentheses - variable description in table 3 
Finally, since the effect of some institutions might be better captured when interacted with the economic factor they have been designed for - for example, Ghent system with unemployment, indexation clauses with inflation, unemployment subsidy with unemployment -, we also experimented several specifications with interaction effects (the statistically significant interactions are reported in table A.4.2 in Appendix 4, which builds on the specification reported in column 4 of table 4). ${ }^{38}$ Results indicate that some institutional variables are correctly signed and statistically significant. In particular, the unemployment variable in the "Ghent" countries (Finland, Sweden, Denmark and Belgium) is positive, indicating that the value of being a union member is higher when unemployment benefits are directly administered by unions themselves and the risk of losing the job is also high. Similarly, the substitute effect played by employment protection is stronger in countries where unemployment is high, suggesting the presence of insider effects replacing union membership. Finally, the higher is the generosity of unemployment subsidies in countries where unemployment is high, the lower is the incentive to "buy" union protection.

Before discussing the explanatory power of our model and its implications for the evolution of unionisation in Europe, we have performed a number of sensitivity tests to check the robustness of our results. First we look at the predictive power of our model. Our preferred specification (column 3 in table 4) with time varying institutions and country fixed effects is quite accurate in explaining differences in the evolution of unionisation patterns across countries. In Figure 6 we plot both actual and fitted union density rates from 1960-65 to 1990-95: the fit is quite good and the model does a good job tracking the major changes occurred in unionisation across Europe.

Next, since misspecification or measurement error could bias our estimates, we performed a number of tests and experimented with different specifications, different definition for the variables and sensitivity to the inclusion of a different set of countries (see appendix 4 for a more detailed discussion). First we investigated whether results were significantly affected by the inclusion (exclusion) of any of the countries considered. Second, we experimented how excluding one institutional feature at a time, or alternatively by introducing each institution on its own affected results. Finally, in order to evaluate the impact of other variables on unionisation patterns, not included in our reference specification, we also experimented a number of additional specifications. As an example, we introduced country size to capture the incentive to form a union, we included the level of "activism" proxied by the average number of workers involved in a strike ${ }^{39}$, finally we also experimented a large set of other controls (which never achieved statistical significance) such as real wages, D5/D1 decile range, long-run growth rates, capital controls, etc. In general our preferred specifications proved highly robust to most of the sensitivity checks performed maintaining signs and (in almost all cases) statistical significance

\footnotetext{
38 To save on degrees on freedom, we also experimented a non-linear model - as in Blanchard and Wolfers (2000) - in which the whole set of institutions is interacted with either time effects or country-specific economic factors. The model did not perform well and most of the interactions turned out to be non significant. The main reason for this, is probably due to the fact that the impact of institutions and economic factors on unionisation, is not of a general form but only works through selected effects of the relevant institutional features on economic shocks.

${ }^{39}$ However the interpretation of a strike variable in our specification is not straightforward, as it might be the case that strike activity (particularly when measured, as in our case, by strike participation) is significantly influenced by union density itself. Also, the issue of whether strikes should be considered as an indicator of strong (or weak) bargaining power, is much debated in the literature. For the above reasons we refrain from entering the strike variable in our preferred specification.
} 
Figure 6 - Actual and Predicted Union Density rates in Europe (1960-65 to 1995-2000) (13 countries)

(mean) den

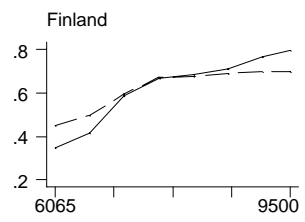

Norway

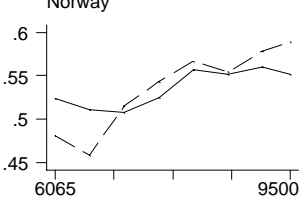

WestGermany

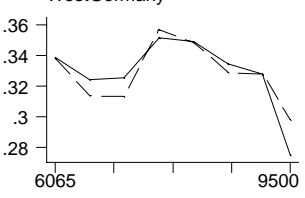

Switzerland

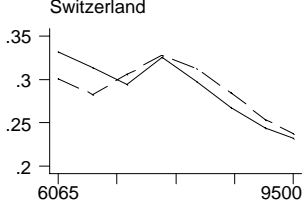

---- Fitted values
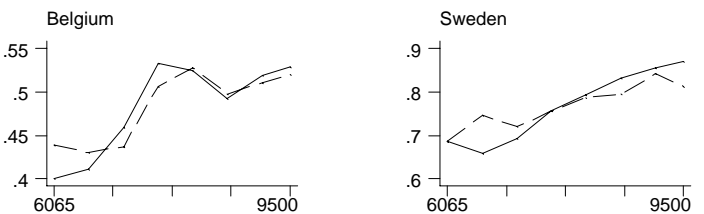

Italy

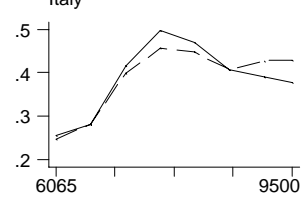

GreatBritain

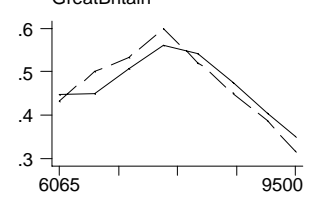

Austria
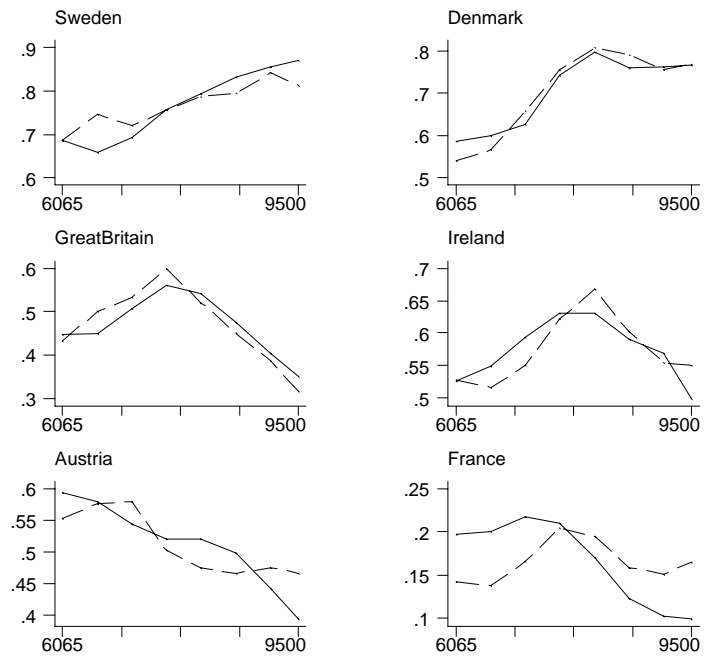

reland

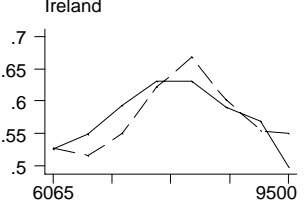

France

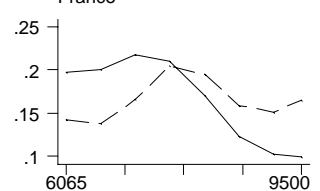

Model prediction in sample

\section{Accounting for differences}

Referring back to table 1, where we listed labour market institutions, we can now assess empirically the overall effects of institutional factors, as well as identifying which institutions mainly act as "union complements" (either lowering the cost of unionising or providing private incentive goods to members) and which operate as "union substitutes" (by reducing income/employment variability and lowering the implicit demand for union protection). For descriptive purposes and in order to use the larger available set of institutions while not relying too much on country fixed effects, in table 5 we have reported the results of our preferred specification when country fixed effects are excluded (column 4 in table 4). Signs and statistical significance, however, have proved robust under alternative specifications for most of the variables included.

We find particularly interesting the result that employment protection legislation "substitutes" demand for union services. As previously discussed, even if unions might have pushed for the introduction and extension of employment protection norms in most countries, such policies (in the longer run) appear to have weakened union membership. Similarly, mandatory extension and wage indexation strengthening the incentive to free-ride have proved detrimental to union membership. Unemployment subsidies, replacement rate and benefit duration also seem to reduce the incentive to join the unions, and not surprisingly so if they make the outside option less risky.

On the contrary, some institutions seem to have a positive effects on union density. For example, workplace representation and union centralisation affect membership by lowering the cost of membership, while direct administration of unemployment benefit (though publicly subsidised) 
provides a privately appropriable benefit to members. High minimum wage (relative to average wages) seem favourable to unions: in this case, the lower is dispersion in the lower tail of the wage distribution, the higher is solidarity among workers and stronger the cohesiveness in collective bargaining and industrial action. While the presence of a wage floor often goes hand in hand with the existence of employment protection legislation (Bertola 1999), still the two features seem to impact differently on union density. Finally, the tax wedge resulted to exert a positive impact (with time-varying institutions), thus corroborating the hypothesis that unions gain credit in protecting (net) wages and find a more favourable environment in a centralised bargaining settings. The positive impact of the share of public sector employment on union density shows that unions as rent-seekers are more successful in economic context where rents are high and market competition is limited.

Table 5 - Summary results and institution classification

\begin{tabular}{|c|c|c|c|c|}
\hline LABOUR MARKET INSTITUTIONS & $\begin{array}{c}\text { ESTIMATED } \\
\text { COEFFICIENT } \\
4^{\text {th }} \text { column of table } 4\end{array}$ & $\begin{array}{c}\text { UNION } \\
\text { SUBSTITUTES }\end{array}$ & $\begin{array}{c}\text { UNION } \\
\text { COMPLEMENTS }\end{array}$ & $\begin{array}{c}\text { RENT } \\
\text { SEEKING }\end{array}$ \\
\hline Employment protection (EP) & $-0.104 * *$ & & & \\
\hline Unemployment benefit replacement rate (BRR) & $-0.088^{*}$ & & & \\
\hline Unemployment benefit duration (BD) & $-0.186^{* *}$ & & & \\
\hline Wage indexation (INDEX) & $-0.054 * *$ & & & \\
\hline Mandatory extension (MANDAT) & $-0773 * *$ & & & \\
\hline Unempl. benefit administered by unions (GHENT) & $0.226^{* *}$ & & & \\
\hline Minimum wages (KAITZ) & $2.044 * *$ & & & \\
\hline Workplace representation rights (WORK) & $0.221 * *$ & & & \\
\hline Bargaining centralisation (CENTR) & $0.200 * *$ & & & \\
\hline Tax wedge (Tw) & $0.365^{* *}$ & & & \\
\hline Governmental employment (PA) & $1.191 * *$ & & & \\
\hline
\end{tabular}

To illustrate better our results and provide a clearer interpretation, we report - for each country - the (average) predicted unionisation levels and the contribution of each set of variables. In practice, in order to assess the relative importance of each factor in explaining unionisation patterns (over the entire period), we computed the overall effects using estimated coefficient and (average) characteristics of RHS variables in each country. Results reported in table 6 are obtained using our preferred specification that includes time varying institutions with compositional and economic factors, as well as country and time fixed effects (as reported in the $3^{\text {rd }}$ column of table 4). Each figure in the table (from column 3 to 8 ) has to be read as the contribution in density points that can be attributed to that group of variables. For comparison purposes in the first column we also report the (average) actual density.

When we look at the average unionisation level over the whole period, the compositional and economic factors account on average for almost $20 \%$ of the predicted levels, while the rest is accounted by institutional factors and fixed effects. ${ }^{40}$ Labour market institutions jointly explain a significant portion of density variation (with opposite signs and a prevailing role played by union complement measures) and the remaining variation can be attributed to rent seeking behaviours

The relevance of economic and institutional factors is quite different across countries, and the combination of complement and substitute (to union activities) institutional arrangements adds further heterogeneity in the overall picture. For example, we can compare two countries, choosing one with high predicted union density, such as Sweden, and one with a relatively low density level, such as the Netherlands. To explain the different outcome in predicted union density it can be noted that while both countries experienced -- in the sample period considered -- a similar dynamics in compositional and economic factors the effects of product market rents and institutional change had been significantly different. On the one hand, in the Netherlands both lower rents and a weaker impact of

\footnotetext{
${ }^{40}$ Note that fixed effects are also likely to capture the effect of some (time invariant) institutional features not included here, such as the Ghent system, Kaitz index and mandatory extension, as well as others.
} 
union-complement institutions seem to account for the progressive decline of union density, on the other hand in Sweden, over the same period, a significant growth in public sector rents as well as the introduction of union-complement institutions contributed to the significant rise in membership. A further example can be provided by looking at Great Britain and Italy. In terms of the institutional setting, it appears that the long-run union density level in Great Britain is the result of both lower than average 'complement' and 'substitute' factors, while in Italy even if the contribution of 'complement' institutional factors is higher than average, the latter is more than compensate by a very generous set of protection measures ('union-substitute') which, on average, seem to have weakened the presence of unions. Table 6 - Predicted (average) union density level and contribution of economic
and institutional factors -13 countries $-1960-2000$

\begin{tabular}{l|c|c|c|c|c|cc|c|} 
& $\begin{array}{c}\text { actual } \\
\text { density }\end{array}$ & $\begin{array}{c}\text { predicted } \\
\text { density }\end{array}$ & $\begin{array}{c}\text { country } \\
\text { fixed effects }\end{array}$ & $\begin{array}{c}\text { composition } \\
\text { al factors }\end{array}$ & $\begin{array}{c}\text { economic } \\
\text { factors }\end{array}$ & $\begin{array}{c}\text { institutional } \\
\text { factors } \\
\text { (substitute) }\end{array}$ & $\begin{array}{c}\text { institutional } \\
\text { factors } \\
\text { (complement) }\end{array}$ & $\begin{array}{c}\text { rent } \\
\text { seeking }\end{array}$ \\
\hline Finland & 0.559 & 0.622 & 0.086 & 0.107 & 0.036 & -0.162 & 0.312 & 0.244 \\
Belgium & 0.461 & 0.484 & 0.070 & 0.129 & 0.022 & -0.233 & 0.247 & 0.249 \\
Sweden & 0.753 & 0.768 & 0.049 & 0.120 & 0.037 & -0.131 & 0.344 & 0.351 \\
Denmark & 0.681 & 0.705 & 0.052 & 0.156 & 0.034 & -0.188 & 0.312 & 0.339 \\
Norway & 0.535 & 0.536 & -0.062 & 0.112 & 0.034 & -0.201 & 0.335 & 0.318 \\
Italy & 0.383 & 0.386 & -0.029 & 0.112 & 0.045 & -0.207 & 0.293 & 0.172 \\
Great Britain & 0.464 & 0.467 & -0.091 & 0.129 & 0.040 & -0.103 & 0.246 & 0.246 \\
Ireland & 0.549 & 0.574 & 0.094 & 0.142 & 0.040 & -0.108 & 0.162 & 0.243 \\
West Germany & 0.337 & 0.328 & -0.065 & 0.151 & 0.017 & -0.185 & 0.236 & 0.175 \\
Netherlands & 0.332 & 0.317 & -0.037 & 0.154 & 0.023 & -0.191 & 0.197 & 0.171 \\
Austria & 0.533 & 0.511 & 0.044 & 0.186 & 0.024 & -0.143 & 0.236 & 0.166 \\
France & 0.181 & 0.165 & -0.431 & 0.122 & 0.031 & -0.144 & 0.262 & 0.326 \\
Switzerland & 0.302 & 0.288 & -0.076 & 0.136 & 0.021 & -0.096 & 0.132 & 0.170 \\
full sample & $\mathbf{0 . 4 5 7}$ & $\mathbf{0 . 4 7 3}$ & $\mathbf{- 0 . 0 3 1}$ & $\mathbf{0 . 1 3 5}$ & $\mathbf{0 . 0 3 1}$ & $\mathbf{- 0 . 1 6 1}$ & $\mathbf{0 . 2 5 5}$ & $\mathbf{0 . 2 4 4}$ \\
\hline
\end{tabular}

Note: 'compositional' includes male industrial employment share (MMM); 'economic' includes inflation rate (INFL) and unemployment rate (UNE); 'substitute' institutions includes duration (BD) and coverage (BRR) of benefits, wage indexation clauses (INDEX) and employment protection (EP); 'complement' institutions includes centralisation in bargaining (CENTR), workplace representation (WORK) and tax wedge (TW); 'rent seeking' includes public employment share (PA).

Finally, we use our model to construct a number of counterfactual experiments: we analyse what would have been the long-term (average) level of unionisation in Sweden if it were to be characterised by the same set of institutions as those prevalent, over the entire period, in the Netherlands. The average union density level which would have prevailed in Sweden, under Dutch institutions, is 0.371 - which compares with an actual figure of 0.753 . As previously described, the combination of lower rents and less favourable union environment if applied to Sweden would have reduced by a half the post-war unionisation rate. Conversely, the reverse would have happen in the Netherlands, under Swedish institutions, where the long-run unionisation rate is estimated to be 0.678 - which compares with an actual figure of 0.332. A further experiment could be that of comparing France and the UK. Quite interestingly, if the same institutional features that are prevalent in the UK should apply to France, unions would decline even more (union density rate would be 0.123 as opposed to 0.181) while French institutions in the UK would slightly increase union density ( 0.483 as opposed to actual figure of 0.463$)$. In both the examples considered, the combination of institutions that are complementary to union activity in one country if transferred to another country seem to produce - ceteris paribus - a substantial increase in long-term unionisation rates. Conversely, when institutions that are perceived as substitute to union activity have an important role, then the impact is likely to be negative. The point which is worth further investigation is try to characterise how labour market institutions interact among them. That is, can we identify some common institutional patterns across countries and over time which help explaining how institutions interacted and evolved over time in the countries considered. In order to 
explore the possibility of institutional clustering, we applied factor analysis to union density and to our set of time varying labour market institutions (principal component method - see table A.4.6 in Appendix 4). The two first components extracted account for over $80 \%$ of total variance, and the variable contribution can be interpreted along the complement-substitute institutional divide. The first component bears a positive correlation between union density and workplace representation, centralisation and tax wedge; the second component displays a negative correlation between density and both employment protection and wage indexation. ${ }^{4}$ We interpret the first component as the impact of 'union-complement' institutions, whereas the second captures mainly 'union-substitute' institutions. For each country and for each time period we computed the score attached to each component, and plotted them in figures $7 \mathrm{a}$ and $7 \mathrm{~b}$. Both graphs have been constructed reporting on the vertical axis the factors which, through 'substitute' institutions, contribute to (long-term) union density; while on the horizontal axis 'complement' institutions to unionisation are reported. In this context, the scattered points represent the 'gravity' centres with respect to the contribution of the complement-substitute components and can be interpreted as a synthetic measure of the institutional environment affecting individual decisions with respect to union membership decisions (i.e. either by country or over time). In interpreting the results, it can be noted that the South-East quadrant represents the best combination for the prosperity of unions, as it combines low 'substitute' with high 'complements' institutions; conversely the North-West quadrant reflects the worst combination as the union has to operate in a very unfavourable environment characterised by a very generous welfare State and lower union rights for workers, to imply that workers have low incentive to demand union protection, and unions in turn have limited ability to deliver it.

Figure 7 a portraits country long term union density along the complement-substitute dimensions. The cluster of Nordic countries, characterised by the highest density rates in the sample, score highest on the complementary dimension, without being reduced by excessive employment protection. Mediterranean countries (Italy, France but also Spain, being possible to predict its components for the last decade only) exhibit high values on the substitute axis, as if they were providing excessive guarantees to the workers thus depressing the incentive to join a union. ${ }^{42}$ Great Britain and Ireland, where labour standards are low, are located at the opposite extreme. Austria and Belgium come out as the countries with the closest institutional mix to the European average.

As to evolution over time, figure $7 \mathrm{~b}$ shows that in European countries -- over the sample period considered -- institutions evolved so as to create a favourable union environment until the end of the 1970 s (i.e. shift along the "complement" axis). In this period unions gained considerable importance in collective bargaining, worker representation and strike rights. It is in those decades that the Italian Statuto dei Lavoratori (possibly the most favourable work legislation among European countries) as well as the British 'closed shop' became binding. Later on generous welfare systems (i.e. unemployment benefits and other subsidies) and employment protection measures progressed until the end of the 1990s in most countries (i.e. upward rise along the "substitute" axis). More recently a policy reversal -mainly for 'union substitute' measures -- has taken place as it is apparent from the distribution of points along the vertical axis (i.e. downward fall along the "substitute" axis). Labour market deregulation, lower employment protection and decentralisation in collective bargaining, higher use of temporary contracts, reform of unemployment benefit schemes, as well as (only in some cases) lower representation rights characterise most European countries. Examples are Mrs. Thatcher's labour market reforms (abolition of the 'closed shop and lower strike rights), the abolition of the scala mobile in Italy and the widespread 'welfare to workfare' move in the reform of the welfare in European countries.

The evolution along both complement-substitute dimensions, which to some extent compensate each other, explains why a significant union density decline (North-American-style) has been confined only

\footnotetext{
${ }^{41}$ Unemployment benefit duration and replacement are rather independent, since they load on the third component.

42 Actually Italy and France are a case on their own, as they combine at the time very different set of institutions, such as low unemployment benefit and high employment protection (Italy) or relatively generous benefit with a rather decentralised bargaining structure and low representation rights (France).
} 
to selected countries. Indeed only Great Britain and, to some extent, the Netherlands are the countries which in the graph show a move towards the North-West quadrant (see table A7 in the Appendix). The case of France is also quite interesting since, for most of the period considered, it could depicted as the case in which the State by providing most services and allowing a generalised extension of collective contracts makes the unions almost totally superfluous, however given the presence of a large public sector (and the associated economic rents) most union members are public sector employees. Finally, it should not came as surprise to see that the recent attempts of the Italian government to reform the legislation on employment protection (art. 18, 'Statuto dei lavoratori'), thus increasing the possibility for employers to dismiss employees, has led to a renewed major workers' participation in strikes and other union activities. 
Figure 7a-Country averages for two first components

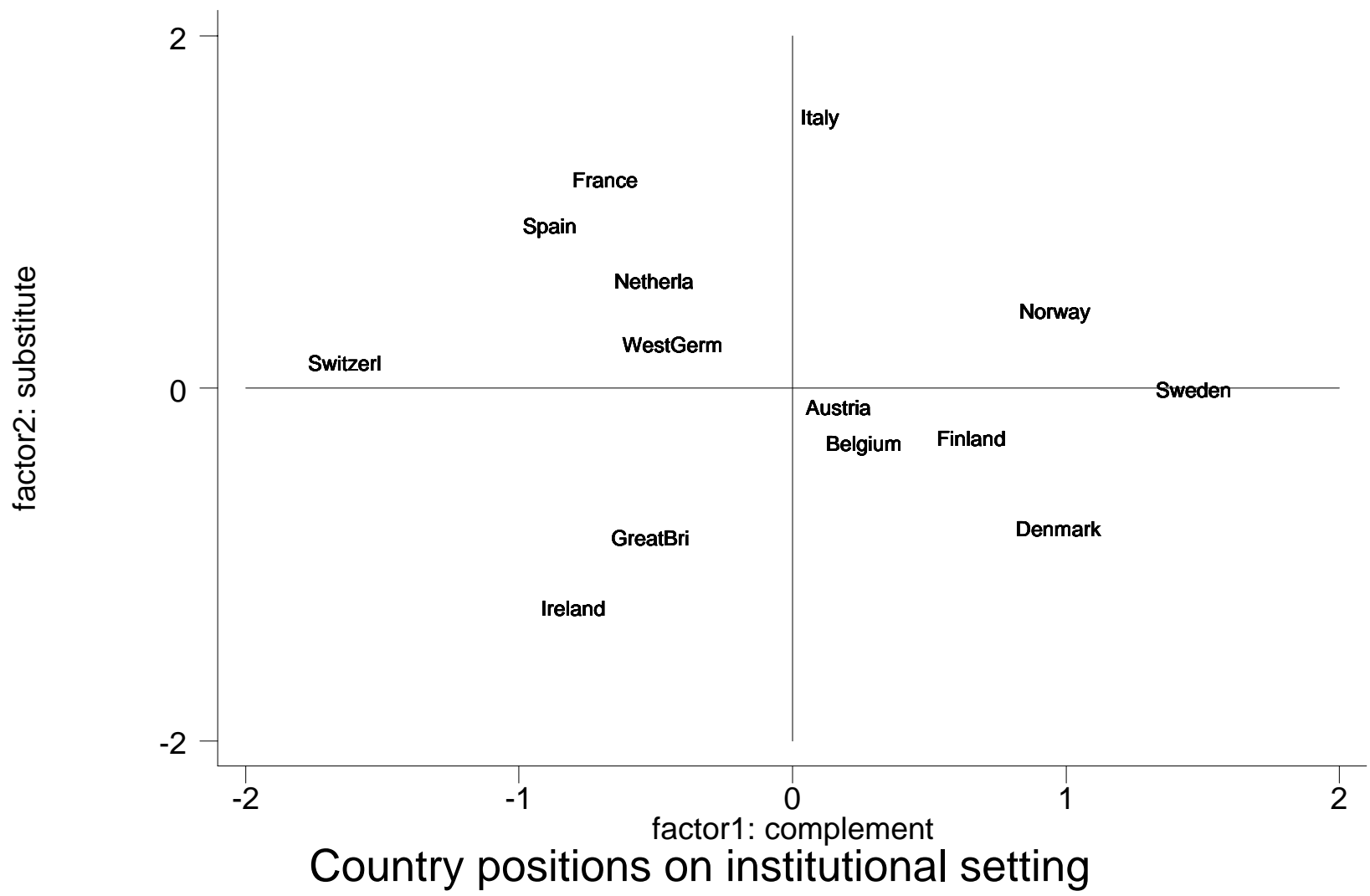

Figure $7 b-$ Year averages for two first components

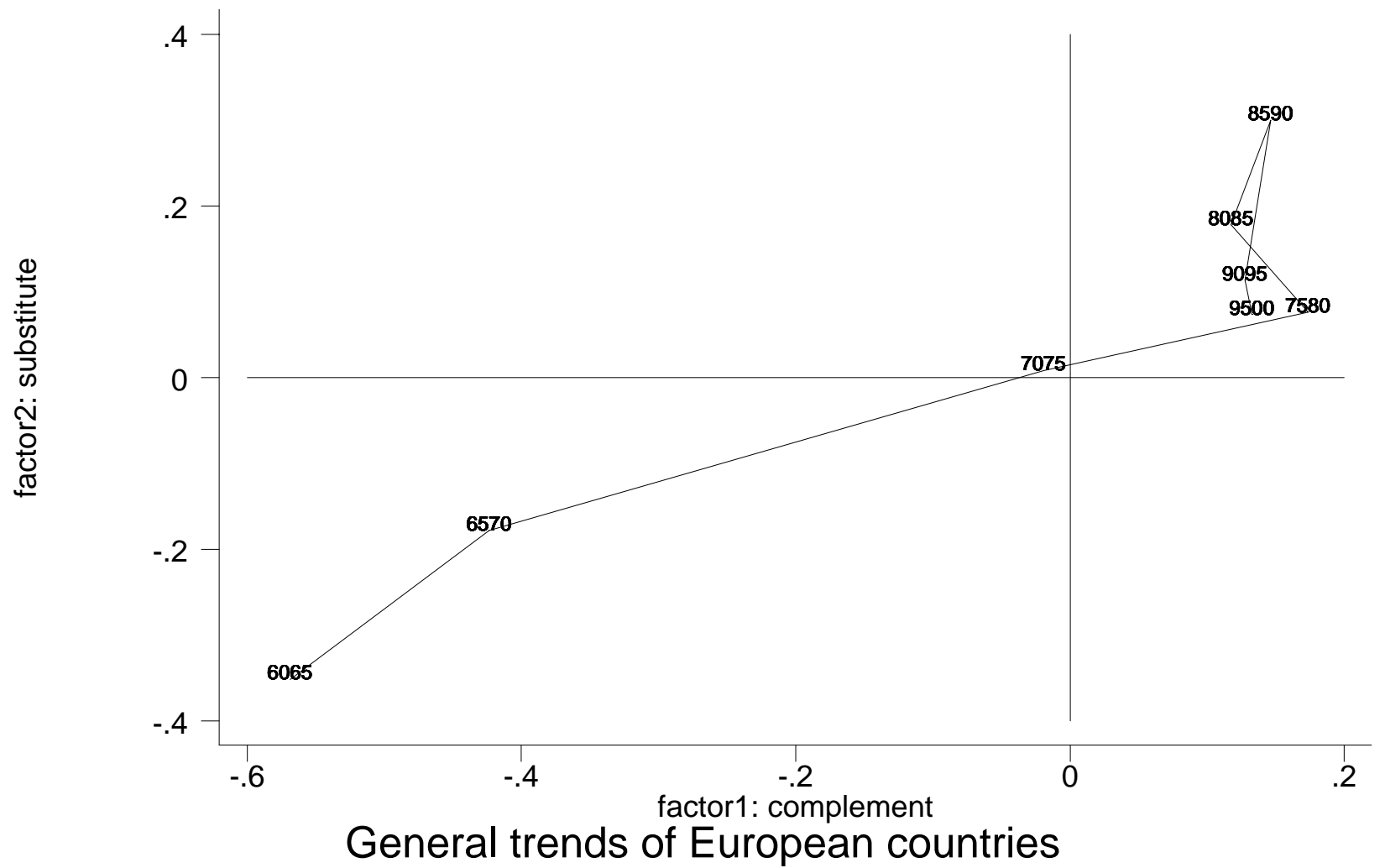




\section{Policy issues and concluding remarks}

In this section, on the basis of the evidence presented, we review the main results and discuss some of the policy implications. First, our results suggest that there is no generalised downward union density trend in Europe. Aggregate figures show a progressive decline, but conceal a highly heterogeneous picture where countries with high and growing membership coexist with others where unionisation is low and declining. Second, while a "bad" view of unions seeing monopolistic behaviour and rent seeking activities in highly protected sectors (i.e. public sector in primis) as the main objectives of unions find some support, we also document the importance of a "good" view of unions where it plays a role as a provider of insurance against labour market risks, namely inflation and unemployment. Third, we show how union membership is itself related to the economic and institutional environment. The institutional setting can have opposite effects: institutions that are "union friendly" rise workers' incentives to join unions, while government policies aimed at protecting workers can act as substitute for union services. Employment protection legislation, wage indexation, statutory minimum wages ceteris paribus - appear to crowd out unions; conversely, workplace representation and centralisation of bargaining have a positive effect on unionisation.

These results offer interesting implications for very topical policy reform issues. Empirical support for a "positive" role of unions in protecting workers against otherwise uninsurable labour market risks suggests that this role is potentially more relevant the higher is the "risk" and the lower is the universal insurance offered by State-provided schemes. Thus, both union activity and government intervention can play a risk-reducing role in labour markets significantly exposed to both inflation and unemployment risks. In this respect, the role of unions is likely to depend very much on the design of the policy mix concerning deregulation, privatisation and reduced welfare provisions that are currently in the policy agenda of a number of European countries. To the extent that reforms contribute to a diffuse feeling of reduced protection and more insecurity, workers might be more inclined to seek protection with the unions, thus increasing membership.

However, the ability of unions to provide services is conditioned by the "friendliness" of the institutional environment in which unions operate; in other words, restrictions to organisational activity, increasing fragmentation of bargaining and reduced coverage of negotiated agreement can significantly rise the costs and reduce membership. And, while government schemes are in general meant to benefit all individuals - or targeted to specific groups on the basis of need, when means tested - union practices have often been directed to the benefit of the "insiders" (current members) at the expenses of the "outsiders" (potential members). However, for the "good" role of unions to be effective in increasing membership, union practices must be encompassing such as to represent the needs of all workers and not just of the "insiders". Institutions such as the Ghent system are the clear example that it is from the "outsiders" that the demand for union services is likely to emerge.

Policies directed to the reduction of public sector expenditures and public sector employment can also have important effects. A smaller public sector means reduced rents to be extracted and thus reduced membership among public sector workers; however, to the extent that public sector jobs crowd out private sector jobs and increase unemployment, a countervailing effect on overall membership can be expected. The effects of rent extraction on membership outside the public sector are more controversial: increased competition and growing openness to international trade, while reducing the scope for rent seeking behaviour, also increase exposure to internal and external economic risks. What is less ambiguous, however, are the effects on the composition of union members, which will probably count less on public sector and "male-manual-manufacturing" workers to the benefit of more private service workers. 
Along these lines, it is likely that the stability pact for those countries within the EMU, by reducing the significance of inflationary shocks but not necessarily that of unemployment shocks, would adversely impact on unionisation patterns. Less immediately, the Amsterdam treaty and the European Social Charter invoke common standard across European countries with respect to welfare provision as well as worker rights. The net effect on unionisation is likely to depend on the relative effect of the two. And while the process of convergence towards a common set of institutional measures might be expected to lead a convergence in union densities across European countries, high heterogeneity of industrial relations systems, and restricted degrees of freedom in responding to idiosyncratic shocks, still leave a lot of uncertainty as to possible future evolutions.

Finally, the results offer intriguing insights into the possible attitudes of union leaders vis-à-vis the above scenario and the process of institutional change. The idea that unions are not isolated from the institutional context and that workers demand insurance against labour market risks makes it particularly interesting to assess the political feasibility and union consensus over the agenda of labour market reforms. To the extent that viability of unions depend on the institutional environment in which they operate, (non-myopic) union leaders may oppose reforms that are likely to act, in the long run, as substitute for their services; while favour institutions that are complementary to their activity. From this point of view, it is puzzling to witness resistance by European union leaders against attempts of governments to reduce labour market regulation. This might be explained either arguing that unions are mainly concerned with "insiders" rather than all potential workers, or simply saying that union leaders are myopic and, being mainly concerned with their term of service, neglect longer term effects. Conversely, of course, unions should obviously favour work-place representation (such as European work councils), recommended by the European Social Charter as a means of building trust between workers and managers. In general, when designing institutional changes, it should be borne in mind that altering the balance between institutions that are complements or substitutes to union activities can have complex effects on union relevance and behaviour. 


\section{References}

Acemoglou, D., P.Aghion and G.Violante. (2000). Deunionisation, technical change and inequality. mimeo.

Agell, J. (1999), "On the Benefits from Rigid Labour Markets: Norms, market Failures and Social Insurance", Economic Journal ,109, F143-F164.

Agell, J. (2000), "On the Determinants of Labour Market Institutions: Rent Sharing versus Social Insurance", CESifo, Working Paper \#384.

Akerlof, G. (1980). A theory of social custom, of which unemployment may be one consequence. Quarterly Journal of Economics 95: 749-775.

Algan, Y., Cahuc, P. and A. Zylberberg (2002). "Public Employment. Does it increase employment?", Economic Policy, 7-66.

Andrews, M. and R.Naylor. (1994). Declining Union Density in the 1980s: What Do Panel Data Tell Us? British Journal of Industrial Relations 32/3: 413-31.

Belot, M. and van Ours (2000), "Does the recent success of some OECD countries in lowering their unemployment rates lie in the clever design of their labour market reforms ?", CEPR wp.2492.

Bertola, G. (1990). Job security, employment and wages. European Economic Review 6, 851-886.

Bertola, G. (1999), "Microeconomic perspectives on aggregate labour markets", in O. Ashenfelter and D. Card, Handbook of Labor Economics, North-Holland, 3c: 55-74.

Bertola, G., F.Blau and L.Kahn (2001), Comparative analysis of labour market outcomes: lessons for the US from international long-run evidence, NBER Working Paper n.8256

Blanchard, O. and F. Giavazzi (2001). "Macroeconomic Effects of Regulation and Deregulation in Goods and Labour markets", NBER Working Paper n.8120.

Blanchflower, D., R.Crouchley, S.Estrin and A.Oswald (1990). Unemployment and the demand for unions. NBER wp n.3251, May.

Blanchard, O. and J. Wolfers (2000), "The role of shocks and institutions in the rise of European unemployment: the aggregate evidence", Economic Journal ,110/462: C1-C33.

Boeri, T., G. Nicoletti and S. Scarpetta (2000), "Regulation and labour market performance", CEPR wp. 2420 .

Boeri, T., G.Garibaldi and M.Macis (2001), “Adaptability of labour markets: a tentative definition and a synthetic indicator", Fondazione DeBenedetti, mimeo.

Boeri, T., A.Brugiavini and L.Calmfors (eds.), with A.Booth, M.Burda, D.Checchi, B.Ebbinghaus, R.Freeman, P.Garibaldi, B.Holmlund, R.Naylor, M.Schludi, T.Verdier, and J.Visser (2001). The future of collective bargaining in Europe. Oxford: Oxford University Press

Booth, A. (1983). A reconsideration of trade union growth in the United Kingdom. British Journal of Industrial Relations 21: 379-93.

Booth, A. (1984), "A public choice model of trade union behaviour and membership", Economic Journal, 94: 883-898.

Booth, A. (1985), "The free rider problem and a social custom model of trade union membership", Quarterly Journal of Economics, 100: 253-261.

Booth, A. and M.Chatterji (1995). Union membership and wage bargaining when membership is not compulsory. Economic Journal 105: 345-360.

Booth, A.(1995). The economics of the trade union. Cambridge University Press 1995

Braun, A.R. (1976). Indexation of wages and salaries in developed economies. Staff Papers IMF, v.23/1: 226-271

Bruno, M., and J.Sachs (1985). Economics of worldwide stagflation. Oxford: Basic Blackwell.

Burda, M. (1990). Membership, Seniority and Wage-Setting in Democratic Labour Unions. Economica 57/228: 455-66.

Calmfors, L., and J.Driffill. (1988). Centralisation of wage bargaining and macroeconomic performance. Economic Policy 6: 13-61.

Calmfors, L. (1993). Centralisation of wage bargaining and macroeconomic performance: a survey, OECD Working Papers $n .131$ 
Card, D. (1998). Falling Union Membership and Rising Wage Inequality: What is the Connection ?, NBER Wp.6520, April

Carruth, A. and C.Schnabel (1990). Empirical Modelling of Trade Union Growth in Germany, 19561986: Traditional versus Cointegration and Error Correction Methods. Weltwirtschaftliches ArchivReview of World Economics 126/2: 326-46.

Carruth, A. and R.Disney (1988). Where have two million trade union members gone?, Economica 55, 1 19.

Checchi, D. and G. Corneo (2000), "Trade union membership. Theory and evidence for Italy", Lavoro e Relarioni Industriali , 2: 1-36

Checchi, D. and J.Visser (2001), "Pattern persistence in European trade union density", University of Amsterdam-AIAS working paper n.4

Corneo, G. (1995), "Social custom, management opposition, and trade union membership", European Economic Review, 39: 275-292.

Corneo, G. (1997). The theory of the open shop trade union reconsidered. Labour Economics 4: 71-84.

Daveri, F., and G.Tabellini. 2000. Unemployment, growth and taxation in industrial countries. Economic Policy 30: 49-104.

DiNardo, J., N.Fortin and T.Lemieux. (1996). Labour market institutions and the distribution of wages, 1973-1992: a semiparametric approach. Econometrica 64(5): 1001-1044.

Dolado, J., F.Kramarz, S.Machin, A.Manning, D.Margolis and C.Teulings. (1996), The economic impact of minimum wage in Europe, Economic Policy 23, 317-372

Ebbinghaus, B and Visser, J, (1999), "When Institutions Matter: Union Growth and Decline in Western Europe, 1950-1995”, European Sociological Review, 15 (2).

Ebbinghaus, B. and J.Visser (2000), Trade Unions in Western Europe since 1945, MacMillan.

Farber, H. (2001). Notes on the economics of Labor Unions, Princeton University - Industrial Relations section working paper n.452

Flora, P., F.Kraus and W.Pfenning. (1987). State, Economy and society in Western Europe 1815-1975, McMillan.

Freeman, R. (1984). "Unionism Comes to the Public Sector", Journal of Economic Literature, 1-41.

Freeman, R. and J.Pelletier (1990). The impact of industrial relations legislation on British union density, British Journal of Industrial Relations 28/2, 141-164.

Garibaldi, P. and Mauro P. (1999), "Deconstructing Job creation", IMF, wp.99/109

Golden, M., Lange, P. and M.Wallerstein. (1997). Union centralization among advanced industrial societies: an empirical study (data downloaded at http://www.shelley.polisci.ucla.edu/data on 3/4/2001)

Gregg, P. and A. Manning (1997), "Labour Market Regulation and Unemployment", in D. Snower and G. de la Dehesa (eds.), Unemployment Policy - Government Options for the Labour Market, Cambridge University Press: Cambridge.

Grossman, G. (1983). Union wages, temporary layoffs, and seniority. American Economic Review 73/3: $277-90$.

Grubb, D. and Wells W. (1993), "Employment regulation and patterns of work in EC countries", OECD Economic Studies, 21.

Hancké, B. (1993), "Trade Union Membership in Europe,1960-1990: Rediscovering Local Unions", British Journal of Industrial Relations, 31/4: 593-613.

Holmlund, B. and P. Lundborg. (1999), "Wage Bargaining, Union Membership, and the Organization of Unemployment Insurance", Labour Economics, 6/3: 397-415.

Jones, S. and C.J.McKenna. (1994). A Dynamic Model of Union Membership and Employment. Economica 61/242: 179-89.

Kahn, L. (2000). Wage inequality, collective bargaining and relative employment. )85-94: evidence from 15 OECD countries. forthcoming in The Review of Economics and Statistics

Kremer, M. and B.Olken (2001). A biological model of unions. NBER working paper n.8257

Lange, P. and L.Scruggs (1999). "Where have all members gone? Union density in an era of globalization". Stato e Mercato, Vol. 55, pp. 39-75. 
Layard, R., S.Nickell and R..Jackman. (1991). Unemployment: macroeconomic performance and the labour market. Oxford University Press, 1991.

Lazear, E. (1990). Job security provisions and employment. Quarterly Journal of Economics, August, 699726.

Lipset, S. and I.Katchanovski. (2001). Corporatism, left government and union density in advanced Western countries. mimeo

Mackie and Rose. (1974). International Almanac of Electoral History, reported in "CODEBOOK FOR 18NATION POOLED TIME-SERIES DATA SET: Strength of Political Parties by Ideological Group in Advanced Capitalist Democracies" by Duan Swank (downloaded at http://www.marquette.edu/polisci/p5095code.htm on 5/7/2001)

Moore, W., R.Newman and L.Scott. (1989). Welfare expenditure and the decline of unions. Review of Economics and Statistics 71(3): 538-542.

Naylor, R. and M.Cripps (1993). An economic theory of the open shop trade union. European Economic Review 37: 1599-1620.

Naylor, R. and O.Raaum (1993). The open shop union, wages and management opposition. Oxford Economic Papers 45: 589-604.

Nickell, S. (1997), "Employment and labor market rigidities: Europe versus North America", Journal of Economic Perspectives, 11/3: 55-74.

Nickell, S. and Layard, R. (1999), "Labour market institutions and economic performance", in O. Ashenfelter and D. Card, Handbook of Labor Economics, North-Holland, 3c: 3029-84.

Nickell, S., L.Nunziata, W.Ochel and G.Quintini (2001). The Beveridge curve, Unemployment and wages in the OECD from the 1960's to the 1990s. LSE-CEP, mimeo, July.

Nicoletti, G., Scarpetta, S. and Boylaud, O. (2000), "Summary indicators of product market regulation with an extension to employment protection legislation", OECD, Working Papers n. 226.

Nicoletti, G. and S.Scarpetta. (2001). Interactions between product and labour market regulations: do they affect employment? Evidence form OECD countries. forthcoming as OECD Economic Department Working paper

Okun, A. (1981). Prices and quantities: a macroeconomic analysis. Washington: Brookings Institution.

OECD (1999). Employment Outlook. Paris (Chpt.2 - Employment protection and labour market performance)

OECD (2001). Employment Outlook. Paris (Chpt.4 - Eligibility criteria for unemployment benefits - by D.Grubb)

Oskarsson, S. (2001). "Class struggle in the wake of globalization - union organization in an era of economic integration". forthcoming in L. Magnussen and J. Ottosson (eds.), Europe: One Labour Market? Brussels.

Pehkonen, J. and H.Tanninen. (1997). Institutions, Incentives and Trade Union Membership. Labour 11/3: 579-98.

Peoples, J. (1998). "Deregulation and the Labor Market", Journal of Economic Perspectives, 12 (3), 111-130.

Rogers, J. and W.Streeck (1995), Works Councils. Consultation, Representation and Cooperation in Industrial Relations, University of Chicago Press, Chicago.

Saint-Paul G. (1996), "Exploring the political economy of the labour market institutions", Economic Policy, 23, 263-317

Scarpetta, S. (2002). "Regulation, Productivity and Employment: An International Comparison and the Challenge for Italy", mimeo.

Scharpf, F. and V.Schmidt (eds) (2000). Welfare and work in the open economy (vol.1), Oxford University Press

Summers, L., J.Gruber and R.Vergara (1993). Taxation and the structure of labor markets: the case of corporatism. Quarterly Journal of Economics 108/2: 385-411.

Traxler, F., Blaschke, S. and Kittel, B. (2001). National Labour Relations in Internationalized markets - A comparative study of institutions, change and performance. Oxford University Press

Van Ours J. C., (1992), "Union Growth in the Netherlands 1961-1989”, Applied Economics, 24, 10591066. 
Visser, J, (1993), "Union Organisation: Why Countries Differ", The International Journal of Comparative Labour Law and Industrial Relations, 9.

Waddington, J. and C.Whitston (1997). Why Do People Join Unions in a Period of Membership Decline? British Journal of Industrial Relations. 35/4: 515-46.

Webb, S. and B. Webb (1894), The History of Trade Unionism. London

Western, B. (1997), Between class and market. Postwar unionization in the capitalist democracy, Princeton University Press, Princeton. 


\section{Appendix 1 - A formal model of union density}

Our model is based on Booth (1984) with two significant modifications: workers are homogenous with respect to risk aversion, but they are heterogeneous in ability (as in Agell 2000); the firm does not follow a discriminatory hiring rule (such that union members are the first to be hired and the last to be fired), but union members obtain a higher probability to retain their employment status (thank to implicit employment protection offered by union representatives).

If we think of ability as a relevant input in job search (it could include professional skills, family background and related social networks, or even unobservable intelligence), different workers have different employment probabilities, even if jobs are identical. However, this probability can be raised by joining the union and taking advantage of privately appropriable services offered by the union itself (information on job opportunity, off-the-job training, etc.). As we will see in the sequel, union demand emerges from less skilled workers, that use unions status to compensate their lower endowment of ability.

A union is modelled as a democratic institution pursuing the will of the median member. The union acts as a monopolist in setting a wage for all workers, independently from their union status, given a labour demand from the firm. A union also set the membership cost (union dues), given a production technology of union services. Membership does not enter in union goals per se. ${ }^{43}$

Workers are risk adverse and have preferences described by a utility function in the CRRA (constant relative risk aversion) class

$$
U(x)=\frac{x^{\sigma}}{\sigma}, \sigma<1
$$

where $(1-\sigma)=-\frac{U^{\prime \prime} x}{U^{\prime}}$ is the coefficient of risk aversion.

Employment is unilaterally determined by $n$ firms operating in a one commodity economy. Free entry is prevented by assumption: as a consequence, firms are price setters, and rents are available for bargaining with the unions. Firms have identical technology in the CES (constant elasticity of substitution) class

$$
Y_{i}=\left(L_{i}^{\rho}+K_{i}^{\rho}\right)^{\frac{1}{\rho}}, \quad \rho<1, \quad i=1, \ldots, n
$$

Profit maximisation leads to the following labour demand

$$
L_{i}=Y_{i}\left(\frac{P}{P_{i}}\right) \cdot\left(\frac{P_{i}}{W}\right)^{\frac{1}{1-\rho}}, \quad i=1, \ldots, n
$$

where we have assumed that output demand for firm $i$ depends on its relative price with respect to the market. Since the union is wage setter with respect to all firms, and all firms are identical, there is a

\footnotetext{
${ }^{43}$ We have here a potential contradiction, because low membership renders it implausible a monopolistic setting of the wage rate (see the discussion on this point in Booth 1995, chpt.4). A more realistic modelling strategy would have been to use wage bargaining with relative power based on density, but the algebra becomes unmanageable. Therefore our results should be taken as indicative of first order effects.
} 
unique price level and therefore a unique real wage. As a consequence, aggregate employment is obtained by simple summation across firms

$$
L=\sum_{i} L_{i}=\sum_{i} Y_{i}\left(\frac{P}{W}\right)^{\frac{1}{1-\rho}}=Y\left(\frac{P}{W}\right)^{\frac{1}{1-\rho}}
$$

Let us define the aggregate employment rate as

$$
\pi=\frac{L}{L F}=\frac{Y}{L F}\left(\frac{P}{W}\right)^{\frac{1}{1-\rho}}=A W^{-\eta}=\pi(W)
$$

where $L F$ is the labour force, and $A$ is a demand shifter: an increase in output demand raises the employment probability, whereas an exogenous increase in the labour force reduces the same probability. Finally, $\eta$ is the wage elasticity of the labour demand.

If workers are heterogeneous with respect to employment probability (also interpretable as retention probability), we model this heterogeneity as a zero-mean additive component to the aggregate employment probability

$$
\pi_{j}=\pi(W)+\alpha_{j}, \quad \alpha \in[-\lambda, \lambda]
$$

where $\pi_{j}$ is the employment probability of worker $j$. We assume that $\alpha_{j}$ be uniformly distributed over the $[-\lambda, \lambda]$ support, so that in the aggregate $E\left[\pi_{j}\right]=\pi(W)$.

A typical worker joins the union, pays a fraction $\beta$ of her salary as union dues and obtain the benefits of union protection (in terms of increased employment probability) $\varepsilon$ as long as ${ }^{44}$

$$
\left(\pi_{j}+\varepsilon\right) \frac{[W(1-\beta)]^{\sigma}}{\sigma}+\left(1-\pi_{j}-\varepsilon\right) \frac{B^{\sigma}}{\sigma}>\pi_{j} \frac{W^{\sigma}}{\sigma}+\left(1-\pi_{j}\right) \frac{B^{\sigma}}{\sigma}
$$

where $B$ is the unemployment benefit, assumed lower that wage net of union dues (i.e. $B<W(1-\beta)$ ). Inequality (7) can be rearranged as

$$
\underbrace{\varepsilon\left\{[(1-\beta)]^{\sigma}-B^{\sigma}\right\}}_{\text {expected gain from membership }}>\underbrace{\pi_{j}\left\{W^{\sigma}-[W(1-\beta)]^{\sigma}\right\}}_{\text {expected cost from membership }}
$$

By replacing $\pi_{j}$ with its expression, we find the marginal worker, who is indifferent between becoming union member or not; we denote her with $\alpha_{\text {marg }}$

$$
\alpha_{\text {marg }}=\varepsilon \frac{[W(1-\beta)]^{\sigma}-B^{\sigma}}{W^{\sigma}-[W(1-\beta)]^{\sigma}}-A W^{-\eta}=\varepsilon \frac{(1-\beta)^{\sigma}-\left(\frac{B}{W}\right)^{\sigma}}{1-(1-\beta)^{\sigma}}-A W^{-\eta}
$$

\footnotetext{
44 Actually, this is a first order approximation, since at equilibrium the increased employment probability for union members is obtained at the cost of reduced employment probability for non members. This effect is negligible when density is low, but becomes more relevant when it rises.
} 
Equation (9) describes what Booth (1984) calls the "membership curve"; for any given wage there corresponds a different marginal workers. This curve is reported in figure A.1.1, where it can be seen that this relationship shifts to the right (i.e. for any given wage there is an increase in membership) for $\Delta \beta<0$ (reduced cost of membership), $\Delta B<0$ (increased cost of unemployment status) and $\Delta \varepsilon>0$ (increased union benefit). Analogously, individual incentives to union membership increases during recession $(\Delta A<0)$ or under less elastic technologies $(\Delta \eta<0)$.

Figure A.1.1 - The membership curve

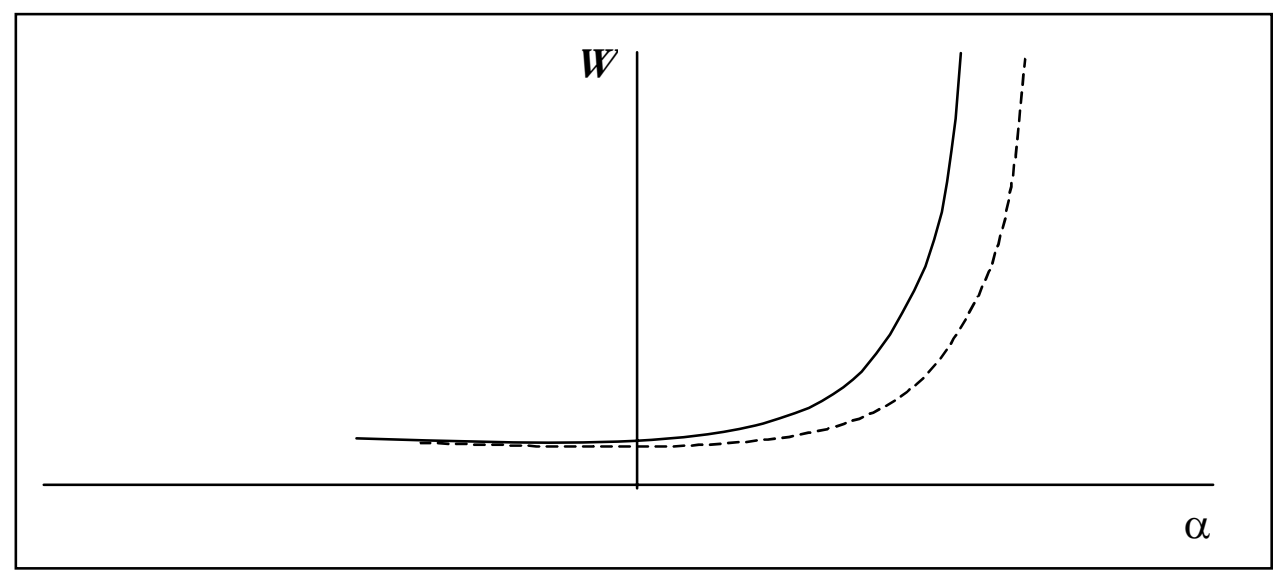

Since workers are randomly allocated among firms, a centralised union sets an identical wage for all firms by maximising the expected utility of the median member, indicated with $\alpha_{\text {median }}$. Union density does not enter separately the union leaders objective function. Given the uniform distribution assumption, the median member is located in the middle point between $-\lambda$ and $\alpha_{\text {marg }}$, namely

$$
\alpha_{\text {median }}=\frac{\alpha_{\text {marg }}-\lambda}{2}
$$

In addition, the union also sets the cost of membership, given a "production technology" for union protection (characterised by decreasing returns). Thus the union problem can be formalised as

$$
\begin{gathered}
\max _{W, \beta}\left(\pi_{\text {median }}+\varepsilon\right) \frac{[W(1-\beta)]^{\sigma}}{\sigma}+\left(1-\pi_{\text {median }}-\varepsilon\right) \frac{B^{\sigma}}{\sigma} \\
\text { s.t. } \varepsilon=\varepsilon(\beta), \varepsilon^{\prime}>0, \varepsilon^{\prime \prime}<0
\end{gathered}
$$

or correspondingly

$$
\max _{W, \beta}\left(A W^{-\eta}+\frac{\alpha_{\operatorname{marg}}-\lambda}{2}+\varepsilon(\beta)\right) \frac{[W(1-\beta)]^{\sigma}-B^{\sigma}}{\sigma}+\frac{B^{\sigma}}{\sigma}
$$

From the first FOC we derive what Booth (1984) calls the "wage equation", which corresponds to the optimal wage set by the union for any given marginal worker

$$
\alpha_{\text {marg }}=\lambda-2\left\{\varepsilon(\beta)+\frac{A}{W^{\eta}}\left(\frac{\sigma-\eta}{\sigma}\right)+\frac{A \eta}{\sigma W^{\eta+\sigma}}\left(\frac{B}{1-\beta}\right)^{\sigma}\right\}
$$


This curve is reported in figure A.1.2, and it can take two shapes (according to whether $\sigma \leq \eta$ or $\sigma>\eta)$. It can be easily proved that this relationship shifts to the right (i.e. for any given marginal member the union sets a lower wage) for $\Delta \beta<0$ (reduced cost of membership), $\Delta B<0$ (lower outside alternative) and $\Delta \varepsilon<0$ (reduced ability to deliver protection). Analogously, the wage set by the union is lower during recession $(\Delta A<0)$.

Figure A.1.2 - The wage curve

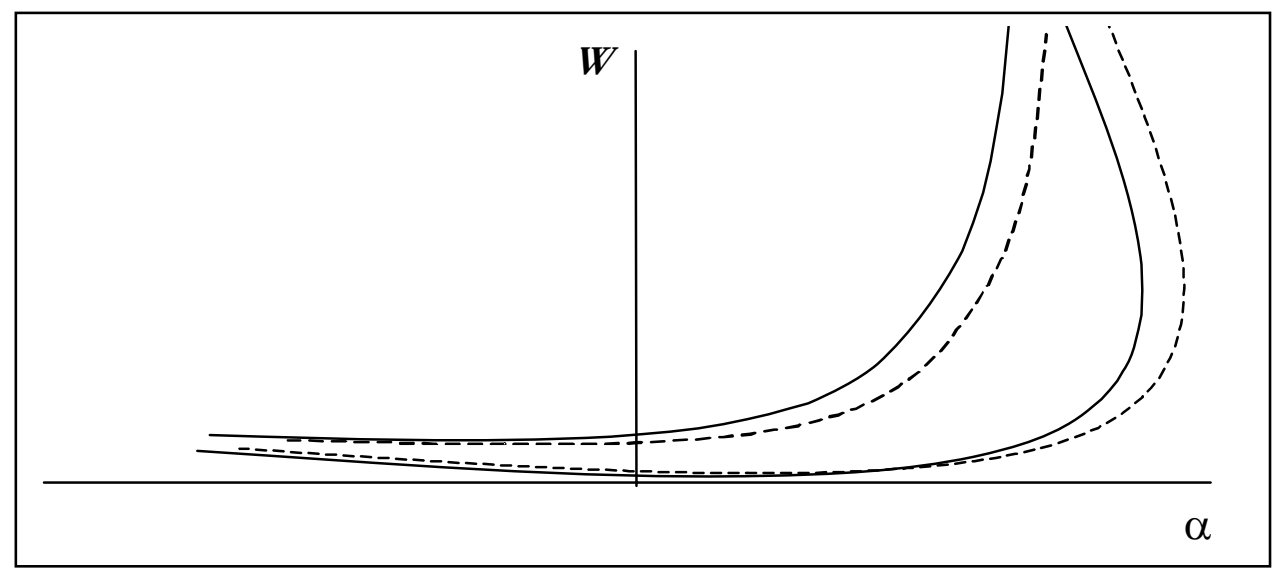

The model exhibits stability if the wage curve is flatter than the membership curve at crossing. ${ }^{45}$ We can also obtain the optimal level of union dues by taking the ratio between the two first order conditions

$$
\frac{A \eta W^{-\eta-1}}{\varepsilon^{\prime}(\beta)}=\frac{W^{\sigma-1}(1-\beta)^{\sigma}}{W^{\sigma}(1-\beta)^{\sigma-1}} \quad \Leftrightarrow \quad \beta^{*}=1-\frac{\eta A W^{-\eta}}{\varepsilon^{\prime}(\beta)}=1-\frac{\eta \pi(W)}{\varepsilon^{\prime}(\beta)}
$$

By performing comparative static analysis, we can use this model to predict the effect of institutional changes on equilibrium union density:

1) unemployment benefit. If we consider an increase in the unemployment benefit $\Delta B>0$, it reduces individual incentives to join the union; at the same time it induces a more aggressive wage policy. Individual worker improves her expected utility, but the social insurance role for less skilled workers is weakened.

2) employment protection. Our model is unable to deal with public employment protection. We can think of pro-union legislation as an improvement in the efficiency of the "employment protection technology" (namely $\Delta \varepsilon^{\prime}(\beta)>0, \forall \beta$ ). However, we know from equation (14) that improved efficiency induces higher dues. In such a case, $\Delta \varepsilon>0$ induces an increase in density (because an increase in expected benefit from membership), but the correlated increase in dues $(\Delta \beta>0)$ tend to lower the density.

3) demand shock. A positive employment shock reduces the demand for union protection, and in addition raises the negotiated wage. The overall effect on density is negative.

4) labour demand elasticity. An increase in labour demand elasticity $(\Delta \eta>0)$ can be thought as an increase in firm's power, or alternatively an increase in labour market flexibility. At individual level, the

\footnotetext{
${ }^{45}$ Multiple equilibria are possible whenever the curvature of the two curves is very different. In the discussion, we refer to the "good" (i.e. stable) case.
} 
associated reduction in employment probability raises the value of union protection, but at the aggregate level it induces wage moderation, thus lowering the attractiveness of unions. The composite effect is ambiguous.

5) risk aversion. Finally we want to consider the effect of an increase in risk aversion $(\Delta \sigma>0)$. It can be thought as a consequence of reduced social protection by the welfare state. At individual level, it induces an increase in the demand for union insurance, while at the aggregate level it induces wage moderation, thus increasing employment probability. The overall effect is positive.

Table A.1.1 - Summary results of comparative statics

\begin{tabular}{|c|c|c|c|}
\hline MODEL PARAMETERS (LABOUR MARKET INSTITUTIONS) & WORKER INCENTIVES & UNION POLICY & EFFECTS ON DENSITY \\
\hline Unemployment benefit & $\begin{array}{l}\text { reduces expected } \\
\text { benefit from union } \\
\text { protection }\end{array}$ & $\begin{array}{c}\text { more aggressive } \\
\text { wage policy } \\
\text { but } \\
\text { less employment } \\
\text { probability } \\
\text { (increased demand } \\
\text { for protection) }\end{array}$ & $\begin{array}{c}\text { positive } \\
\text { (possibly negative) }\end{array}$ \\
\hline Union ability to deliver employment protection & $\begin{array}{l}\text { increases expected } \\
\text { benefit from union } \\
\text { membership }\end{array}$ & $\begin{array}{l}\text { increased efficiency } \\
\text { induces an increase } \\
\text { in the use of raised } \\
\text { resources (dues) }\end{array}$ & $\begin{array}{c}\text { positive } \\
\text { (negatively only } \\
\text { when dues increase } \\
\text { is significant) }\end{array}$ \\
\hline $\begin{array}{l}\text { Output demand shock } \\
\text { (improved conditions in the labour market) }\end{array}$ & $\begin{array}{l}\text { raises employment } \\
\text { probability and } \\
\text { reduces expected } \\
\text { benefit from union } \\
\text { protection }\end{array}$ & $\begin{array}{l}\text { more aggressive } \\
\text { wage policy } \\
\text { (attenuates the positive } \\
\text { effect on employment } \\
\text { probability) }\end{array}$ & negative \\
\hline $\begin{array}{l}\text { Labour demand elasticity } \\
\text { (greater labour market flexibility) }\end{array}$ & $\begin{array}{l}\text { increases the } \\
\text { demand for union } \\
\text { insurance }\end{array}$ & $\begin{array}{l}\text { less aggressive } \\
\text { wage policy }\end{array}$ & ambiguous \\
\hline Risk aversion & $\begin{array}{c}\text { increases the } \\
\text { demand for union } \\
\text { insurance }\end{array}$ & $\begin{array}{l}\text { less aggressive } \\
\text { wage policy }\end{array}$ & ambiguous \\
\hline
\end{tabular}

This does not exhaust the list of institutions that potentially affect union density, nor the channel through which they exert their effect. We have not considered either wage compression (that is likely to induce a positive demand for union among heterogeneous risk adverse workers) or job tenure (that is likely to induce disaffection for union among people who are very likely to become long term unemployed). We have also collapsed organisational problems of the union in the couple (cost of adhesion, provision of protection), but we are aware that we should tale into account wage indexation, wage setting levels, coverage and government intervention. 


\section{Appendix 2 - Data definition and sources}

The variable DEN (union net density) is derived from Ebbinghaus and Visser 2000, with updates provided by J.Visser. For Finland (1950-59), Belgium (1950-59), Denmark (1950-74), Norway (195055), Netherlands (1950-51), Switzerland (1950-69) net density rates are estimated using the rate of change of gross density rates. In absence of better alternative, in the case of Great Britain and Ireland gross density rates were used instead of net ones.

The variable INFL indicates inflation rate of consumer price index, and has been extracted from OECD Statistical Compendium 1998/2 $(1990=100)$. In the case of Denmark, the CPI index has been extracted from the OECD Main Economic Indicators data-set. For the period 1950-59 we resorted to Maddison's GDP deflator growth rates.

The variable FL (total labour force), EMTO (civilian employment) and POP (total population) are extracted from OECD Statistical Compendium 1998/2. For the period 1950-59 data on labour force and employment were derived using rates of changes of corresponding variables obtained by Flora et al. 1987 (who excludes family workers, whereas OECD data includes them). The variable UNE indicates unemployment rate (unemployed/labour force $=$ FL-EMTO $/$ FL).

The variable MMM corresponds the share of male dependent employment in industry on total employment, and proxies the concept of $3 \mathrm{M}$ (man-manual-manufacturing). Industry includes mining and quarrying, manufacturing, electricity/gas/water, constructions. Data are from OECD Statistical Compendium 1998/2. Data are missing for Denmark, Ireland, Netherlands, Austria; few observations are available for Switzerland. When possible (Sweden 1963-68, Denmark 1960-96, Italy 195-96, Ireland 1960-96, Netherlands 1975-96, France 1960-68, Switzerland 1960-96, Spain 1960-71), missing observations have been estimated using the levels or the growth rates of industry share in total employment. Alternatively missing observations have been replaced with country means, in order not to loose degrees of freedom.

The variable PA indicates the share of governmental employment on total dependent employment. Employees in public services are from OECD Statistical Compendium (variable EPGS) for the period 1970-95; the series has been backwarded using the rate of change for central government employment from Flora et al.. 1987. Where the variable was absent from OECD dataset (Ireland, Switzerland and Spain) we rely on Scharpf and Schmidt 2000.

The variable GHENT indicates whether the country holds an unemployment benefit scheme administered by unions. In the post-war period it applies to Finland, Belgium (where it originates from the beginning of last century), Denmark and Sweden. ${ }^{46}$

The variable INDEX is a step dummy indicating the existence of an indexation clause. It has been constructed by Checchi and Visser 2001, who have been unable to find comparable information about the degree of coverage of these clauses. Most of the information comes from Braun 1976, updated using Ebbinghaus and Visser 2000.

\footnotetext{
46 “'Only in a few European countries has the 'Ghent system'- with the state providing supplementary means to a unionfunded and union-controlled unemployment scheme-survived the shock of the Great Depression of the 1930s. Elements of that system have been retained by the Danish and Swedish unions, and were reintroduced in Finland in the late 1960s. In other countries where it had been operative, for instance, in Norway, the Netherlands or Britain, these systems were replaced by mandatory state schemes. In Belgium, where the Ghent system originated, it was also discontinued but unions still hold on to an administrative role in processing individual benefit cases for their members, thus giving them the possibility of providing preferential treatment (and a highly selective benefit) to members in good standing" (Ebbinghaus and Visser 2000, p.14-15). See Holmlund and Lundborg 1999 for additional details.
} 
The variable WORK is an index varying between 0 and 1 and indicates the extent of workplace presence of unions. Oskarsson 2001 provides basic information, backward extended by Checchi and Visser 2001 relying on country experience accounts reported in Ebbinghaus and Visser 2000.

The variable CENTR combines information about the degree of centralisation in wage bargaining and wage coordination across the main workers unions, on a quinquennial base. See Boeri, Brugiavini and Calmfors 2001, pg.70 ss. The variable HERF is the computed Herfindahl index on the original variable SHARE $i$ which corresponds to the membership share of the $i$ confederation, $i=1,2, . ., 6$, reported in Golden et al. 1997. It is available from 1950 to 1992. Data for Ireland and Spain are desumed from data reported in Ebbinghaus and Visser 2000.

The variable KAITZ reports the Kaitz's index (i.e. the ratio minimum wage/average wage) and is obtained from Dolado et al. 1996.

The variable MANDAT indicates the mandatory extension of collective agreements; it ranges between 0 and 1 and is derived from OECD, Employment Outlook, 1996.

The last four institutional variables have been kindly provided by S.Nickell and are described in Nickell et al.2001 and covers the period 1960-92. The variable EP indicates the degree of employment protection, ranges between 0 and 2 and is obtained from interpolation from the corresponding series computed by Blanchard and Wolfers 2000, which in turn was based on OECD 1999 and on Lazear 1990 for earlier period (who only relied on information on severance pay and notice period).

The variable BRR indicates the benefit replacement rate and is obtained from OECD (data referred to the first year of unemployment benefit). As alternative measure we tried to use the variable BENEFIT that includes both unemployment benefits and social assistance benefits, and has been created as from a weighed average between the average production worker wage and $2 / 3$ of it. The source for the period 1960-96 is the OECD Data-base on Benefit Entitlements and Gross Replacement Rates. For the previous decade we have extended backward the series using the rates of change of the number of unemployed covered by a public benefit (from Flora at al. 1987).

The variable BD is a proxy for both benefit duration and its temporal structure. It ranges from 0 (benefit lasts only one year) to 1 (benefit lasts at least 4 years and the replacement rate does not decline with years). Finally the variable TW is a measure of tax wedge, obtained as a sum of the employment tax rate, the direct tax rate and the indirect tax rate.

As far as market regulation is concerned, we have introduced five alternative measures. The variables MKREG is the overall indicator of product market regulation and is obtained from table A3.7 in Nicoletti-Scarpetta-Boylaud 2000. The data are referred to 1998. The variable MKREGD is obtained from Nicoletti and Scarpetta 2001 and represents a dynamic version of market regulation, including only some aspects (barriers to entry, public ownership, market structure, vertical integration, price controls) and some sectors (gas, electricity, post, telecom, air transport, railways and road freight). Data are referred to $1978-98$.

The variable WAGESH indicates the compensation of employees as percent of GDP market price, private sector (excluding public services), from OECD Statistical Compendium 1998/2. When data are missing (Sweden 1970-80, Norway 1991-97, Ireland 1970-97, Netherlands 1970-77, Austria 1970-97, Switzerland 1970-97) they have been estimated using the rate of change of income from dependent employment as percent of national income from Scharpf and Schmidt 2000. Missing observations have been replaced with country means, in order not to loose degrees of freedom.

The variable OPEN indicates the degree of opening to international trade. For the period 1965-90 is obtained from the Penn tables v.5.6 (Nov.1994) and corresponds to (Export+Imports)/Nominal GDP. 
For the period 1995-98 is obtained from OECD (Economic Outlook). In the intermediate period it has been interpolated by estimating as an $\mathrm{AR}(5)$ process for each country and using the predicted values.

The variable LEFTV contains Left party votes as a percent of total votes, and is obtained from Mackie and Rose 1974 and subsequent extension by Duan Swank. They cover the period 1950-95, but the same variable is not available for Spain.

The variable STRIKE indicates the extent of strike participation, and is obtained as the ratio of workers involved in strikes (source: ILO Statistics) to total dependent employees (source: OECD statistics). For initial years we relied on Flora et al. 1987. 


\section{Appendix 3 - Data description}

\section{Data on union density}

With respect to average union density reported in figure 1 , we can decompose its dynamics into the relative contribution of each country (as it is done in figure A.3.1). ${ }^{47}$ It turns out that Italy and especially Great Britain are the main responsible for the aggregate swing during the 70's and the 80's.

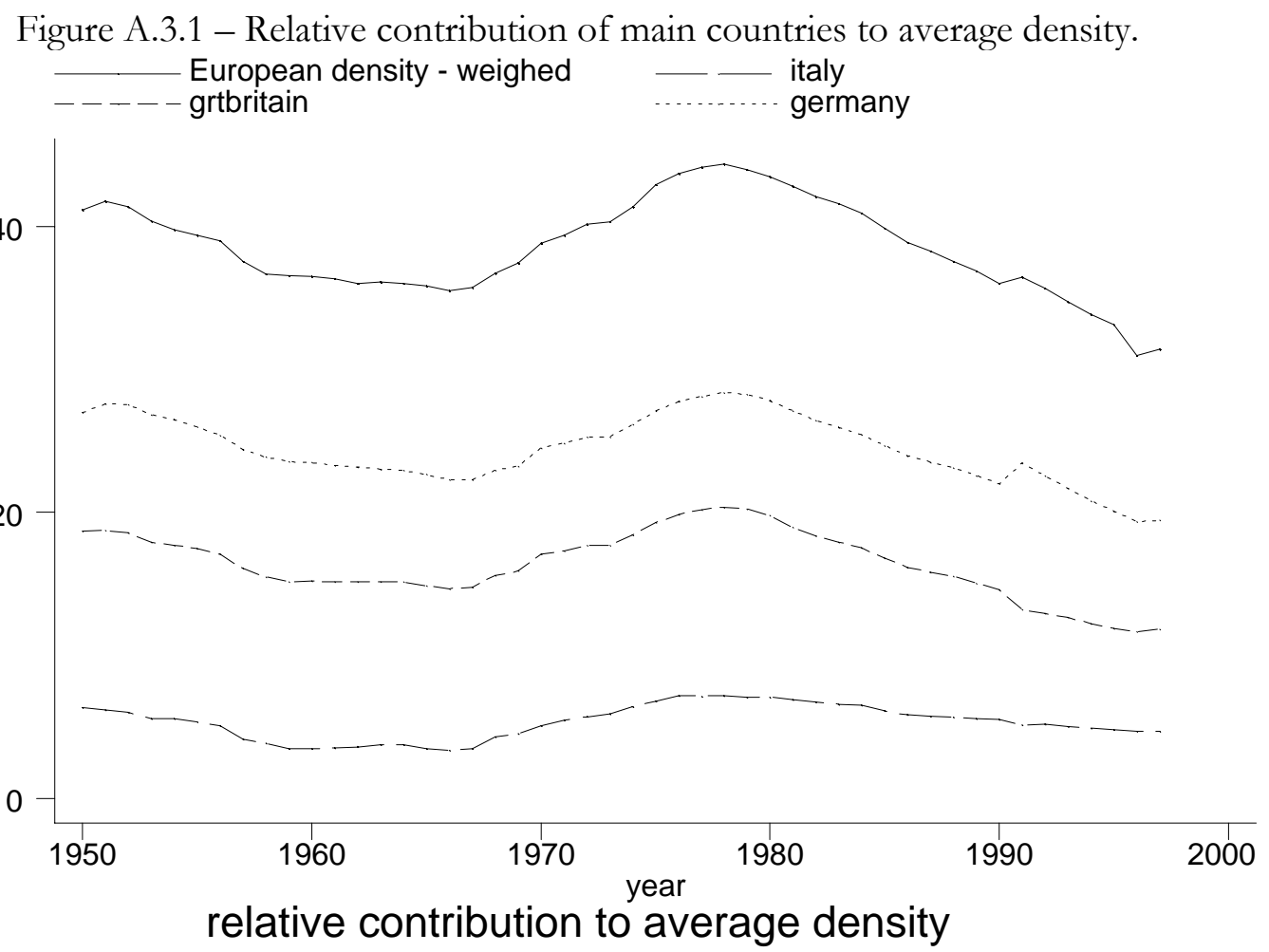

There have been some changes in data collections for union density: introduction of UIL membership in Italy in 1968; introduction of new labour force figures in Sweden in 1963; German reunification and new aggregation in 1991; introduction of CO membership in Spain in 1991. These changes are controlled with appropriate step dummies.

\section{Data on labour market institutions.}

Moving to available empirical measures for labour market institutions, data definition and sources are reported in Appendix 2. Given the limited time variation of institution measures, we use 5-year averages over the available time span. ${ }^{48}$

${ }^{47}$ If we define $m_{i}$ as membership in country $i$ and $n_{i}$ the dependent employment in the same country, country density rate are defined as $\operatorname{den}_{i}=\frac{m_{i}}{n_{i}}$, whereas the European density rate is computed as $\overline{\operatorname{den}}=\frac{m_{1}+m_{2}+\ldots+m_{n}}{n_{1}+n_{2}+\ldots+n_{n}}$. The relative contribution of each country reported in figure A.3.1 is therefore equal to $\frac{m_{i}}{n_{1}+n_{2}+\ldots+n_{n}}=\operatorname{den}_{i} \cdot \frac{n_{i}}{n_{1}+n_{2}+\ldots+n_{n}}$.

48 Similar procedure has been followed by Nickell and Layard 1999, Blanchard and Wolfers 2000, Belot and van Ours 2000 , Bertola, Blau and Kahn 2001. 
With respect to employment protection, OECD (1999) has provided a detailed analysis of several employment protection facets (including regular procedural inconvenience, notice and severance pay for no-fault individual dismissals, difficulty of dismissal, fixed-term contracts, temporary work agency, collective dismissal), building on previous work by Grubb and Wells (1993). However, these variables are measure only at two points of time ("late 80's" and "late 90's"), and therefore we have preferred the measure provided by Nickell et al. (2001) that in turn builds upon a similar series provided by Blanchard and Wolfers (2000) and Lazear (1990). Unfortunately, we do not have time varying information about the degree of coverage of these protections, and therefore are forced to rely on available data. ${ }^{49}$

Unemployment subsidies are described by two series: the replacement rate for the first year of unemployment, averaged over family types of recipients, and a proxy for benefit duration, capturing the extent of subsidy decline over the unemployment spell. The original source of the data is the OECD Data-base on Benefit Entitlements and Gross Replacement Rates, but we make use of Nickell et al. (2001) version for these data. We also control for union involvement in benefit administration with a country dummy pointing to "Ghent" countries. Initial and terminal values for these variables are reported in table A.3.1. Once again, we would like to have comparable measures of eligibility criteria for benefits, but existing information is dispersed (see Grubb in Oecd 2001).

\begin{tabular}{|c|c|c|c|c|c|c|c|}
\hline \multirow{2}{*}{$\begin{array}{l}\text { institutional aspect } \\
\text { variable name } \\
\text { range }\end{array}$} & \multirow{2}{*}{\multicolumn{2}{|c|}{$\begin{array}{c}\text { employment } \\
\text { protection } \\
\text { legislation } \\
\text { NNEPL } \\
0-2\end{array}$}} & \multirow{2}{*}{\multicolumn{2}{|c|}{$\begin{array}{c}\text { unemployment } \\
\text { replacement } \\
\text { ratio } \\
\text { NNBRR } \\
0-1 \\
\end{array}$}} & \multirow{2}{*}{\multicolumn{2}{|c|}{$\begin{array}{c}\text { unemployment } \\
\text { benefit } \\
\text { duration } \\
\text { NNBD } \\
0-1 \\
\end{array}$}} & \multirow{3}{*}{$\begin{array}{c}\text { union } \\
\text { administered } \\
\text { unemployment } \\
\text { schemes } \\
\text { GHENT } \\
0-1 \\
6065-9095 \\
\end{array}$} \\
\hline & & & & & & & \\
\hline country/period & 6065 & 9095 & 6065 & 9095 & 6065 & 9095 & \\
\hline Finland & 1.20 & 1.14 & 0.13 & 0.52 & 0.00 & 0.54 & 1 \\
\hline Belgium & 0.72 & 1.37 & 0.37 & 0.48 & 1.00 & 0.78 & 1 \\
\hline Sweden & 0.00 & 1.56 & 0.11 & 0.73 & 0.00 & 0.05 & 1 \\
\hline Denmark & 0.90 & 0.92 & 0.25 & 0.65 & 0.63 & 0.81 & 1 \\
\hline Norway & 1.55 & 1.47 & 0.11 & 0.62 & 0.00 & 0.50 & 0 \\
\hline Italy & 1.92 & 1.92 & 0.09 & 0.22 & 0.00 & 0.14 & 0 \\
\hline United Kingdom & 0.16 & 0.35 & 0.28 & 0.23 & 0.88 & 0.68 & 0 \\
\hline Ireland & 0.02 & 0.52 & 0.21 & 0.44 & 0.69 & 0.54 & 0 \\
\hline Germany & 0.45 & 1.53 & 0.43 & 0.38 & 0.57 & 0.62 & 0 \\
\hline Netherlands & 1.35 & 1.29 & 0.39 & 0.70 & 0.12 & 0.58 & 0 \\
\hline Austria & 0.65 & 1.30 & 0.15 & 0.35 & 0.00 & 0.74 & 0 \\
\hline France & 0.37 & 1.40 & 0.48 & 0.58 & 0.28 & 0.50 & 0 \\
\hline Switzerland & 0.55 & 0.55 & 0.04 & 0.61 & 0.00 & 0.08 & 0 \\
\hline Spain & 2.00 & 1.76 & 0.28 & 0.68 & 0.00 & 0.27 & 0 \\
\hline
\end{tabular}

The extension of bargaining outcomes is controlled with two time-invariant measures: the extension of collective agreements and the presence of minimum wage (as captured by the Kaitz index, namely the ratio between statutory minimum wage and average wage), both reported in table A.3.1.b. We have not made use of existing data on coverage because of their imprecise measure of the incentive to freeriding. ${ }^{50}$

\footnotetext{
${ }^{49}$ See the interesting discussion in Boeri, Garibaldi and Macis 2001.

50 One potential measure of the incentive to free-riding is given by the "excess coverage" (the difference between coverage and union density - see Boeri et al. 2001). Apart from the different frequency of the two composing series, this variable is strongly correlated with our explanandum variable.
} 
Table A.3.1.b - Labour market institutions: extension of coverage and minimum wage in European countries

\begin{tabular}{|c|c|c|c|c|}
\hline \multirow{2}{*}{$\begin{array}{l}\text { country } \\
\text { variable name } \\
\text { range }\end{array}$} & \multicolumn{2}{|c|}{$\begin{array}{c}\text { extension of collective } \\
\text { agreements } *\end{array}$} & \multicolumn{2}{|l|}{ minimum wage systems } \\
\hline & $\begin{array}{c}\text { MANDAT } \\
\text { country ranking }\end{array}$ & & $\begin{array}{c}\text { KAITZ } \\
0-1 \\
\end{array}$ & \\
\hline country/period & description & $\begin{array}{l}\text { index } \\
8090\end{array}$ & description & $\begin{array}{l}\text { index } \\
8090\end{array}$ \\
\hline Finland & frequent (minister extension) & 12 & nationally negotiated $M W^{*}$ & 0.52 \\
\hline Belgium & almost all agreements & 15 & negotiated monthly $M W$ & 0.60 \\
\hline Sweden & by centralisation & 17 & nationally negotiated $M W^{*}$ & 0.52 \\
\hline Denmark & by centralisation & 17 & nationally negotiated $M W^{*}$ & 0.64 \\
\hline Norway & by centralisation & 17 & nationally negotiated $M W^{*}$ & 0.64 \\
\hline Italy & almost all agreements (by ind.) & 16 & negotiated monthly $M W$ (by industries) & 0.71 \\
\hline United Kingdom & no automatic extension & 3 & statutory $M W$ (bef.1993, selected industries) & 0.40 \\
\hline Ireland & limited to min-wages & 7 & statutory $M W$ (only selected industries) & 0.55 \\
\hline Germany & frequent (small firm) & 12 & negotiated $M W$ (by industries) & 0.55 \\
\hline Netherlands & frequent (minister extension) & 10 & statutory weekly $M W$ & 0.55 \\
\hline Austria & almost all agreements & 16 & nationally negotiated $M W *$ & 0.62 \\
\hline France & very frequent & 14 & statutory bourly $M W$ & 0.50 \\
\hline Switzerland & frequent (minister extension) & 11 & ----- & 0.50 \\
\hline Spain & frequent by industry & 15 & statutory montbly $M W$ & 0.32 \\
\hline
\end{tabular}

Other time varying institutional measures refer to the presence and extent of wage indexation and to a measure of centralisation of wage bargaining. The former variable (introduced by Checchi and Visser 2001) controls for the presence of automatic wage indexation clauses, which stabilise workers purchasing power and reduce income variability, for both union members and non-members. The latter (proposed by J.Visser in Boeri, Brugiavini and Calmfors 2001) controls for both organisational features of unions and prevalent level of wage bargaining. We also want to control for workplace representation rights: since union prerogatives have changed in the sample period, we use a (limited) time varying variable building on Oskarsson (2001). Eventually we also take into account labour taxation with a measure of tax wedge, obtained from Nickell et al. (2001). These last variables are shown in table A.3.1.c.

An overview of our data-set is offered in figure A.3.2, where we have reported the relevant variables measured on a quinquennial base after controlling for country and time effects. There is statistically significant evidence of positive correlation of union density with benefit replacement rate, mandatory extension, Kaitz index, workplace presence and tax wedge, and negative correlation with wage indexation. In table A.3.2 we report country averages of the variables displayed in table 3. 
Table A.3.1.c - Labour market institutions: indexation, centralisation, workplace representation and labour taxation in European countries

\begin{tabular}{|c|c|c|c|c|c|c|c|c|}
\hline \multirow{2}{*}{$\begin{array}{l}\text { variable name } \\
\text { range } \\
\text { country }\end{array}$} & \multicolumn{2}{|c|}{$\begin{array}{c}\text { Wage } \\
\text { indexation } \\
\text { INDEX } \\
0-1 \\
\end{array}$} & \multicolumn{2}{|c|}{$\begin{array}{c}\text { Centralisation } \\
\text { of collective } \\
\text { bargaining } \\
\text { COORD1 } \\
0-1 \\
\end{array}$} & \multicolumn{2}{|c|}{$\begin{array}{c}\text { Work } \\
\text { representation } \\
\text { WORK } \\
0-1 \\
\end{array}$} & \multicolumn{2}{|c|}{$\begin{array}{c}\text { Tax wedge } \\
\text { NNTW } \\
0-1 \\
\end{array}$} \\
\hline & 6065 & 9095 & 6065 & 9095 & 6065 & 9095 & 6065 & 9095 \\
\hline Finland & 1.00 & 0.00 & 0.13 & 0.37 & 0.60 & 1.00 & $\begin{array}{l}0.38 \\
\end{array}$ & 0.63 \\
\hline Belgium & 1.00 & 0.60 & 0.67 & 0.43 & 0.80 & 0.80 & 0.38 & 0.49 \\
\hline Sweden & 0.00 & 0.00 & 0.73 & 0.45 & 1.00 & 1.00 & 0.41 & 0.80 \\
\hline Denmark & 1.00 & 0.00 & 0.51 & 0.36 & 1.00 & 1.00 & 0.32 & 0.59 \\
\hline Norway & 1.00 & 0.00 & 0.51 & 0.43 & 1.00 & 1.00 & . & 0.61 \\
\hline Italy & 1.00 & 0.40 & 0.11 & 0.23 & 0.20 & 0.80 & 0.57 & 0.66 \\
\hline United Kingdom & 0.00 & 0.00 & 0.09 & 0.08 & 0.80 & 0.40 & 0.34 & 0.47 \\
\hline Ireland & 0.00 & 0.00 & 0.11 & 0.57 & 0.40 & 0.44 & 0.23 & 0.40 \\
\hline Germany & 0.00 & 0.00 & 0.20 & 0.21 & 0.40 & 0.60 & 0.43 & 0.52 \\
\hline Netherlands & 0.00 & 0.00 & 0.55 & 0.46 & 0.20 & 0.40 & 0.45 & 0.45 \\
\hline Austria & 0.00 & 0.00 & 0.73 & 0.55 & 0.60 & 0.60 & 0.47 & 0.59 \\
\hline France & 0.00 & 0.00 & 0.09 & 0.07 & 0.20 & 0.40 & 0.55 & 0.66 \\
\hline Switzerland & 1.00 & 1.00 & 0.21 & 0.20 & 0.20 & 0.20 & 0.30 & 0.35 \\
\hline Spain & 0.00 & 0.00 & . & 0.25 & . & 0.40 & 0.19 & 0.47 \\
\hline
\end{tabular}

We would have liked to account also for wage compression. But data availability is limited to recent years (as recognised by Bertola, Blau and Kahn 2001). In addition potential endogeneity has discouraged us to proceed further in using this variable for a subset of countries. However we believe that this point is worth exploring in future research: in figure A.3.3 we have plotted union density against two inequality measures for earnings distribution, lagged one period ( 5 years) to account for endogeneity. In both cases we see a significant negative correlation, that could be taken as indicative of workers dissatisfaction with union wage policies. ${ }^{51}$ When inequality raises in the upper tail of earnings distribution, union protection looses value for skilled workers, who prefer individual bargaining. At the same time, when inequality affects the lower tail of earnings distribution, union implicit insurance becomes less worthy for unskilled workers, and they abandon the union as well. In any case, the limited number of observation available ${ }^{52}$ has induced us to leave this measure apart from the bulk of institutional measures.

\footnotetext{
51 Acemoglu, Aghion and Violante (2000) propose a formal model where unionisation and wage differential both vary in response to technical change, but the incentives to join the union are different according to whether workers are skilled or unskilled.

${ }^{52}$ Data source is Bertola, Blau and Kahn 2001, supplemented when possible with Flora et al. 1987. However we have the following number of observations: Finland (9), Belgium (2), Sweden (10), Denmark (8), Norway (8), Italy (1), Great Britain (10), Ireland (1), West Germany (8), Netherlands (10), Austria (7), France (10), Switzerland (8) and Spain (1).
} 
Fig A.3.2 - Union density and labour market institutions in Europe (1960-1998)
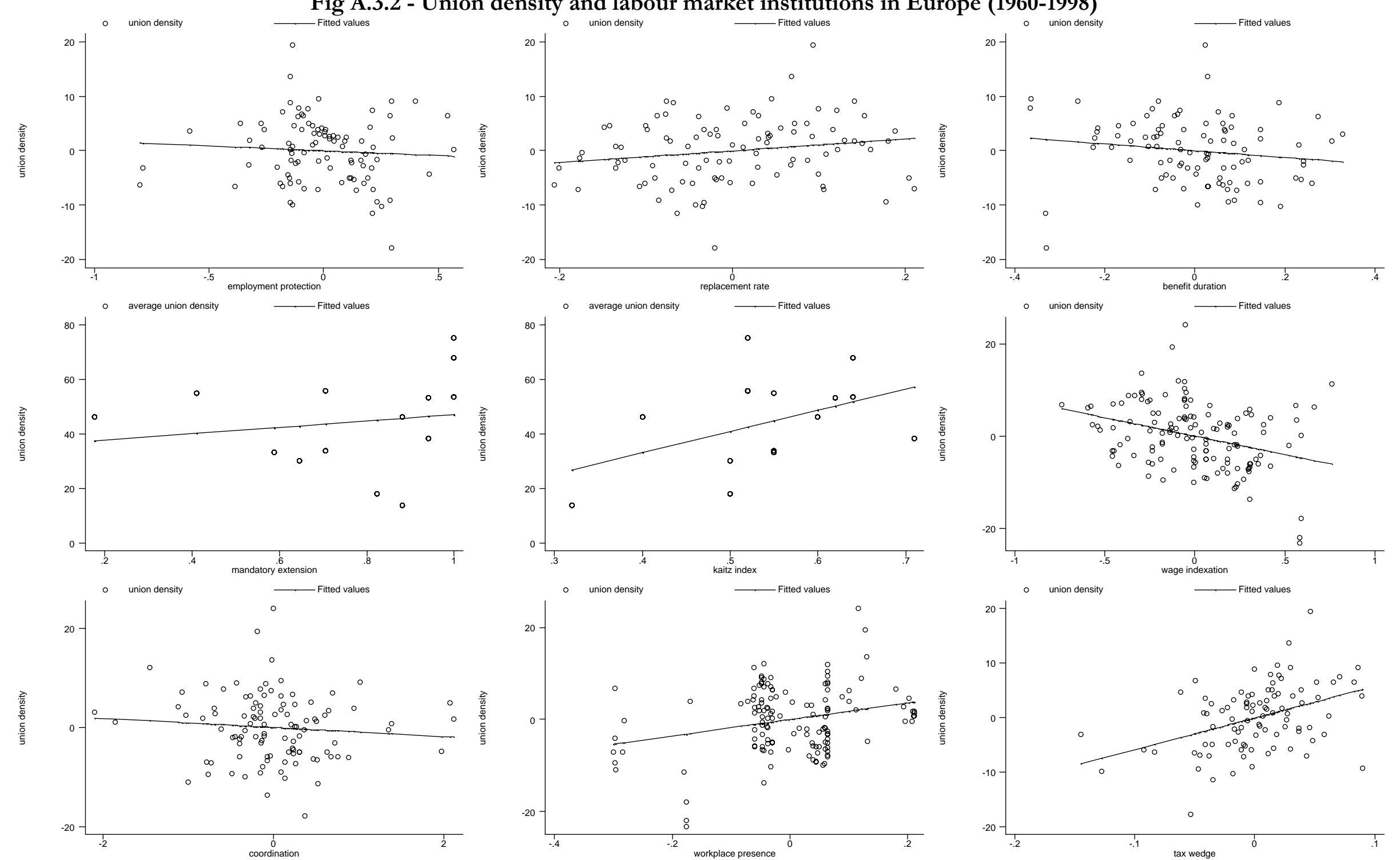

institutions and density 
Fig A.3.3 - Earnings inequality and union density in Europe union density Fitted values

$\frac{\lambda}{0}$
$\frac{1}{0}$
$\frac{0}{0}$
$\frac{1}{\frac{0}{2}}$
$\frac{1}{5}$
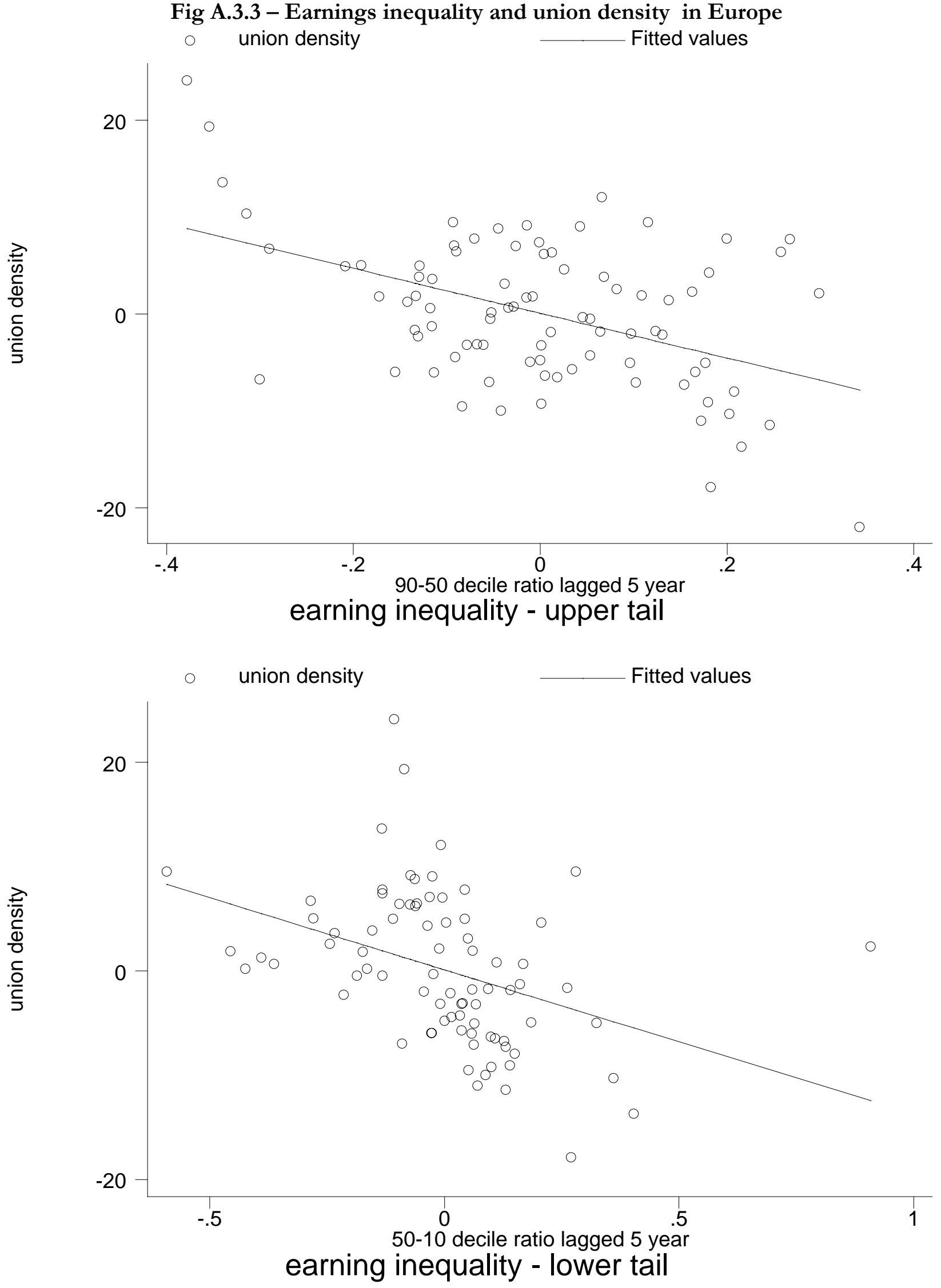
Table A.3.2 - Country means of available variables

\begin{tabular}{|c|c|c|c|c|c|c|c|c|c|c|c|}
\hline country & DEN & MMM & UNE & INFL & BRR & $\mathrm{BD}$ & EP & CENTR & TW & WORK & INDEX \\
\hline Finland & 55.4 & 0.183 & 0.063 & 0.062 & 0.321 & 0.427 & 1.19 & 0.302 & 0.534 & 0.84 & 0.36 \\
\hline Belgium & 45.5 & 0.245 & 0.091 & 0.038 & 0.464 & 0.852 & 1.32 & 0.545 & 0.445 & 0.80 & 0.76 \\
\hline Sweden & 75.0 & 0.215 & 0.028 & 0.058 & 0.477 & 0.030 & 1.07 & 0.623 & 0.655 & 1.00 & 0.40 \\
\hline Denmark & 67.7 & 0.300 & 0.070 & 0.054 & 0.509 & 0.686 & 0.99 & 0.443 & 0.515 & 1.00 & 0.64 \\
\hline Norway & 53.4 & 0.208 & 0.044 & 0.055 & 0.358 & 0.323 & 1.53 & 0.464 & 0.598 & 1.00 & 0.76 \\
\hline Italy & 38.4 & 0.203 & 0.112 & 0.076 & 0.096 & 0.029 & 1.96 & 0.197 & 0.582 & 0.55 & 0.68 \\
\hline Great Britain & 46.6 & 0.255 & 0.060 & 0.064 & 0.292 & 0.675 & 0.29 & 0.123 & 0.449 & 0.68 & 0.08 \\
\hline Ireland & 55.0 & 0.275 & 0.102 & 0.065 & 0.366 & 0.562 & 0.36 & 0.260 & 0.331 & 0.42 & 0.20 \\
\hline West Germany & 33.8 & 0.296 & 0.068 & 0.029 & 0.396 & 0.596 & 1.32 & 0.224 & 0.478 & 0.51 & 0.00 \\
\hline Netherlands & 33.4 & 0.300 & 0.055 & 0.038 & 0.630 & 0.469 & 1.34 & 0.452 & 0.521 & 0.31 & 0.24 \\
\hline Austria & 53.5 & 0.340 & 0.027 & 0.043 & 0.268 & 0.466 & 0.97 & 0.668 & 0.550 & 0.60 & 0.00 \\
\hline France & 18.3 & 0.220 & 0.086 & 0.057 & 0.555 & 0.320 & 1.04 & 0.097 & 0.611 & 0.32 & 0.18 \\
\hline Switzerland & 30.3 & 0.257 & 0.000 & 0.030 & 0.294 & 0.021 & 0.55 & 0.207 & 0.337 & 0.20 & 1.00 \\
\hline Spain & 13.5 & 0.243 & 0.120 & 0.085 & 0.582 & 0.109 & 1.92 & 0.209 & 0.342 & 0.40 & 0.00 \\
\hline Total & 45.8 & 0.253 & 0.067 & 0.054 & 0.401 & 0.398 & 1.13 & 0.349 & 0.497 & 0.62 & 0.37 \\
\hline
\end{tabular}

\begin{tabular}{lccccccccccc} 
country & DEN & KAITZ & MANDAT & PA & MKREG & MKREGD & HERF & OPEN & WAGESH & LEFTV & STRIKE \\
\hline Finland & 55.4 & 0.52 & 0.70 & 0.204 & 1.7 & 5.28 & 0.418 & 0.55 & 0.565 & 0.44 & 0.113 \\
Belgium & 45.5 & 0.60 & 0.88 & 0.199 & 1.9 & 5.28 & 0.377 & 1.23 & 0.619 & 0.35 & 0.022 \\
Sweden & 75.0 & 0.52 & 1.00 & 0.269 & 1.4 & 4.30 & 0.551 & 0.60 & 0.576 & 0.50 & 0.010 \\
Denmark & 67.7 & 0.64 & 1.00 & 0.265 & 1.4 & 5.36 & 0.674 & 0.65 & 0.561 & 0.46 & 0.029 \\
Norway & 53.4 & 0.64 & 1.00 & 0.246 & 2.2 & 4.69 & 0.835 & 0.82 & 0.464 & 0.48 & 0.000 \\
Italy & 38.4 & 0.71 & 0.94 & 0.139 & 2.3 & 5.72 & 0.544 & 0.39 & 0.546 & 0.39 & 0.364 \\
Great Britain & 46.6 & 0.40 & 0.17 & 0.204 & 0.5 & 3.89 & 1.000 & 0.50 & 0.674 & 0.40 & 0.047 \\
Ireland & 55.0 & 0.55 & 0.41 & 0.205 & 0.8 & 5.51 & 0.785 & 1.04 & 0.604 & 0.16 & 0.036 \\
West Germany & 33.8 & 0.55 & 0.70 & 0.139 & 1.4 & 4.95 & 0.719 & 0.50 & 0.546 & 0.40 & 0.000 \\
Netherlands & 33.4 & 0.55 & 0.58 & 0.164 & 1.4 & 5.18 & 0.371 & 0.98 & 0.523 & 0.35 & 0.000 \\
Austria & 53.5 & 0.62 & 0.94 & 0.140 & 1.4 & 4.91 & 1.000 & 0.68 & 0.593 & 0.48 & 0.013 \\
France & 18.3 & 0.50 & 0.82 & 0.263 & 2.1 & 5.78 & 0.372 & 0.40 & 0.519 & 0.43 & 0.108 \\
Switzerland & 30.3 & 0.50 & 0.65 & 0.141 & 1.8 & 4.48 & 0.458 & 0.71 & 0.678 & 0.29 & 0.000 \\
Spain & 13.5 & 0.32 & 0.88 & 0.107 & 1.6 & 4.61 & 0.454 & 0.34 & n.a. & n.a. & 0.266 \\
\hline Total & 45.8 & 0.54 & 0.76 & 0.195 & 1.5 & 5.00 & 0.619 & 0.67 & 0.574 & .398 & 0.067
\end{tabular}

\begin{tabular}{l|c|} 
variable definition & var name \\
\hline union (net) density rate for active dependent employment & DEN \\
share of male dependent employment in industry on total employment & MMM \\
unemployment rate & UNE \\
inflation rate (yearly change) in consumer price index & INFL \\
unemployment benefit replacement rate & BRR \\
index of unemployment benefit duration & BD \\
index of employment protection & EP \\
index of centralisation/coordination & CENTR \\
taw wedge & TW \\
publicly subsidised unemployment benefit administered by unions & GHENT \\
workplace representation & WORK \\
Kaitz index (minimum wage/average wage) & KAITZ \\
mandatory extension of collective agreements & MANDAT \\
share of governmental employment in dependent employment & PA \\
index of product market regulation (overall) & MKREG \\
dynamic index of product market regulation (7 sectors) & MKREGD \\
Herfindahl index over six main unions & HERF \\
degree of openness to international trade (export+import/gdp) & OPEN \\
wage share on value added - private sector & WAGESH \\
share of left voting in general elections & LEFTV \\
workers involved in strike on dependent employment & STRIKE \\
\hline
\end{tabular}




\section{Appendix 4-Resulta and further robustness checks}

Table 7 - Union density and economic factors -13 countries $-1960-2000$

\begin{tabular}{|c|c|c|c|c|c|}
\hline Model : $\quad 1$ & 2 & 3 & 4 & 5 & 6 \\
\hline \multicolumn{6}{|c|}{ 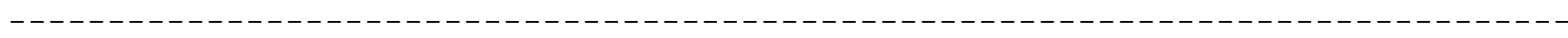 } \\
\hline $\begin{array}{r}\text { unemployment } 0.984 \\
(2.57)\end{array}$ & & $\begin{array}{r}0.832 \\
(1.71)\end{array}$ & & & $\begin{array}{r}0.560 \\
(1.12)\end{array}$ \\
\hline unemployment $_{-1}$ & $\begin{array}{l}0.344 \\
(0.71)\end{array}$ & & & & \\
\hline $\begin{array}{lr}\text { inflation } & 0.807 \\
& (4.44)\end{array}$ & $\begin{array}{r}0.871 \\
(3.65)\end{array}$ & $\begin{array}{r}0.795 \\
(2.51)\end{array}$ & & & $\begin{array}{r}0.895 \\
(1.93)\end{array}$ \\
\hline st.dev. (unempl.) & & & $\begin{array}{r}5.608 \\
(2.45)\end{array}$ & $\begin{array}{r}4.719 \\
(1.84)\end{array}$ & $\begin{array}{l}3.870 \\
(1.48)\end{array}$ \\
\hline st.dev(inflat.) & & & $\begin{array}{r}1.369 \\
(1.50)\end{array}$ & $\begin{array}{r}0.305 \\
(0.26)\end{array}$ & $\begin{array}{l}-0.886 \\
(-0.60)\end{array}$ \\
\hline $\begin{array}{lr}\text { male empl. } & 0.267 \\
\text { indust.shr. } & (1.10)\end{array}$ & $\begin{array}{l}-\odot .098 \\
(-\odot .38)\end{array}$ & $\begin{array}{r}0.409 \\
(0.98)\end{array}$ & $\begin{array}{r}0.092 \\
(0.47)\end{array}$ & $\begin{array}{r}0.494 \\
(1.10)\end{array}$ & $\begin{array}{r}0.411 \\
(0.93)\end{array}$ \\
\hline Constant & Yes & Yes & Yes & Yes & Yes \\
\hline Change-def. Yes & Yes & Yes & Yes & Yes & Yes \\
\hline Country dum. Yes & Yes & Yes & Yes & Yes & $\begin{array}{l}\text { Yes } \\
\text { Yes }\end{array}$ \\
\hline Year dum. & & Yes & & Yes & Yes \\
\hline 0.889 & 0.876 & 0.891 & 0.877 & 0.89 & 0.895 \\
\hline N.obs : & 104 & 104 & 104 & 104 & 104 \\
\hline
\end{tabular}

notes: robust t-statistics in parentheses - variable description in table 3.

Table A.4.1- Union Density, Economic Shocks and Time Invariant Institutions -13 countries $-1960-2000$

$\begin{array}{lccc}\text { Model : } & 1 & 2 & 3 \\ \text { une } & & -0.194 & 0.410 \\ \text { infl } & & (-0.66) & (1.34) \\ & & & \\ \text { brr } & & (1.08) & (3.02) \\ & (1.99) & (-2.48) & (1.12) \\ \text { bd } & -0.385 & -0.370 & -0.367 \\ & (-8.26) & (-8.00) & (-8.06) \\ \text { ep } & -0.166 & 0.018 & 0.003 \\ & (-5.47) & (0.56) & (0.08) \\ \text { centr } & 0.135 & 0.289 & 0.989 \\ & (2.33) & (5.22) & (5.48) \\ \text { ghent } & 0.156 & 0.185 & 0.148 \\ & (5.22) & (6.25) & (4.84) \\ \text { index } & -0.207 & -0.199 & -0.245 \\ & (-6.71) & (-7.28) & (-4.16)\end{array}$




\begin{tabular}{|c|c|c|c|}
\hline work & $\begin{array}{r}0.558 \\
(12.13)\end{array}$ & $\begin{array}{r}0.357 \\
(5.08)\end{array}$ & $\begin{array}{r}0.422 \\
(4.93)\end{array}$ \\
\hline tw & $\begin{array}{r}-0.425 \\
(-2.68)\end{array}$ & $\begin{array}{r}-0.749 \\
(-5.32)\end{array}$ & $\begin{array}{r}-1.757 \\
(-5.75)\end{array}$ \\
\hline kaitz & $\begin{array}{r}1.538 \\
(9.05)\end{array}$ & $\begin{array}{r}1.205 \\
(5.05)\end{array}$ & $\begin{array}{r}1.565 \\
(5.40)\end{array}$ \\
\hline mandat & $\begin{array}{l}-0.351 \\
(-5.07)\end{array}$ & $\begin{array}{r}-0.493 \\
(-7.06)\end{array}$ & $\begin{array}{r}-0.901 \\
(-5.16)\end{array}$ \\
\hline pa & & $\begin{array}{r}1.468 \\
(7.03)\end{array}$ & $\begin{array}{r}1.716 \\
(8.13)\end{array}$ \\
\hline mkreg & & & $\begin{array}{r}0.179 \\
(2.19)\end{array}$ \\
\hline open & & & $\begin{array}{r}-0.459 \\
(-4.02)\end{array}$ \\
\hline $\mathrm{mmm}$ & & $\begin{array}{r}0.669 \\
(2.85)\end{array}$ & $\begin{array}{r}0.341 \\
(1.29)\end{array}$ \\
\hline Constant & Yes & Yes & Yes \\
\hline Definition & Yes & Yes & Yes \\
\hline Year & Yes & Yes & Yes \\
\hline $\begin{array}{l}\mathrm{R}^{2} \\
\# \text { obs : }\end{array}$ & $\begin{array}{l}0.88 \\
104\end{array}$ & $\begin{array}{c}0.933 \\
104\end{array}$ & $\begin{array}{c}0.945 \\
104\end{array}$ \\
\hline
\end{tabular}

Notes: robust t-statistics in parentheses - variable legend in table 3 
Table A.4.2- Union Density, Economic Shocks and Time Varying Institutions with Interaction Effects - 13 countries - 1960-2000

\begin{tabular}{|c|c|c|c|c|}
\hline Model : & 1 & 2 & 3 & 4 \\
\hline brr & $\begin{array}{l}-0.042 \\
(-0.95)\end{array}$ & $\begin{array}{l}-0.043 \\
(-1.08)\end{array}$ & $\begin{array}{l}-0.061 \\
(-1.67)\end{array}$ & $\begin{array}{l}-0.107 \\
(-2.93)\end{array}$ \\
\hline bd & $\begin{array}{r}-0.112 \\
(-2.88)\end{array}$ & $\begin{array}{r}-0.072 \\
(-2.19)\end{array}$ & $\begin{array}{r}-0.079 \\
(-2.48)\end{array}$ & $\begin{array}{l}-0.028 \\
(-0.62)\end{array}$ \\
\hline ep & $\begin{array}{r}-0.088 \\
(-3.42)\end{array}$ & $\begin{array}{r}-0.062 \\
(-2.96)\end{array}$ & $\begin{array}{r}-0.017 \\
(-0.75)\end{array}$ & $\begin{array}{l}-0.021 \\
(-0.96)\end{array}$ \\
\hline centr & $\begin{array}{r}-0.092 \\
(-1.53)\end{array}$ & $\begin{array}{r}0.017 \\
(0.26)\end{array}$ & $\begin{array}{r}-0.076 \\
(-1.18)\end{array}$ & $\begin{array}{l}-0.038 \\
(-0.63)\end{array}$ \\
\hline index & $\begin{array}{r}-0.034 \\
(-1.61)\end{array}$ & $\begin{array}{r}-0.019 \\
(-1.25)\end{array}$ & $\begin{array}{r}-0.017 \\
(-1.25)\end{array}$ & $\begin{array}{l}-0.016 \\
(-1.21)\end{array}$ \\
\hline work & $\begin{array}{r}0.187 \\
(4.05)\end{array}$ & $\begin{array}{r}0.160 \\
(3.49)\end{array}$ & $\begin{array}{r}0.283 \\
(5.73)\end{array}$ & $\begin{array}{r}0.260 \\
(5.08)\end{array}$ \\
\hline tw & $\begin{array}{r}0.425 \\
(3.03)\end{array}$ & $\begin{array}{r}0.368 \\
(3.49)\end{array}$ & $\begin{array}{r}0.30 \\
(3.11)\end{array}$ & $\begin{array}{r}0.336 \\
(3.61)\end{array}$ \\
\hline ghent×une & & $\begin{array}{r}1.680 \\
(5.12)\end{array}$ & $\begin{array}{r}1.712 \\
(5.75)\end{array}$ & $\begin{array}{r}1.864 \\
(6.28)\end{array}$ \\
\hline ep×une & & & $\begin{array}{r}-1.245 \\
(-4.33)\end{array}$ & $\begin{array}{r}-1.181 \\
(-4.13)\end{array}$ \\
\hline bd×une & & & & $\begin{array}{l}-1.178 \\
(-2.07)\end{array}$ \\
\hline Constant & Yes & Yes & Yes & Yes \\
\hline Definition & Yes & Yes & Yes & Yes \\
\hline Countries & Yes & Yes & Yes & Yes \\
\hline Year & Yes & Yes & Yes & Yes \\
\hline Controls & Yes & Yes & Yes & Yes \\
\hline $\begin{array}{l}\mathrm{R}^{2} \\
\# \text { obs : }\end{array}$ & $\begin{array}{c}0.964 \\
104\end{array}$ & $\begin{array}{c}0.976 \\
104\end{array}$ & $\begin{array}{l}\odot .98 \\
104\end{array}$ & $\begin{array}{c}0.981 \\
104\end{array}$ \\
\hline
\end{tabular}


Since the existence of misspecification or measurement error could bias our estimates reported in table 4, we perform a number of tests as well as experimenting different specifications, different definition for the variables and sensitivity to the inclusion of a different set of countries. In general results prove highly robust to most of the robustness checks performed and coefficients maintain their signs and (in almost all cases) statistical significance.

First, given the heterogeneity of country experiences, we investigate whether results are significantly affected by the inclusion (exclusion) of any of the countries considered. In table A.4.3 we re-estimate our model (as in column 4 of Table 4 with time varying institutions) by excluding one country at a time. As the results show, estimates are largely unaffected by the set of countries considered.

Second, we experimented how results are affected by introducing each institution on its own (with and without country fixed effects - see table A.4.4 ). In the first case, results appear unaffected for some regressors (like EP, INDEX, WORK, HERF) whereas some other institutional variables loose significance (like BRR, BD, CENTR, TW, OPEN). In the second case some variables (like BRR and CENTR) gain statistical significance while the other coefficients remain significant, suggesting that they mostly capture cross country variations. The above evidence seems to support the hypothesis that most institutions are more effective, when they come in cluster (rather than on their own) thus reinforcing their mutual effect.

In order to evaluate the impact of other variables on unionisation patterns, not included in our reference specification, we experimented also a number of additional specifications (see table A.4.5). In general, coefficient estimates are largely unaffected by the additional variables included and maintain their statistical significance. For example, when looking at the differences in the levels of union density across countries, it should be acknowledged that country size may have an independent effect on the incentive to form a union. Since fixed costs may play a relevant part in the setting up of a union organisation, countries with a large population (or a large labour market) may devote less resources to the formation of collective institutions (Lipset and Katchanovski 2001). When the log of country's population is included to the set of regressors it shows a negative sign and is statistically significant, while all the other coefficients appear to be unaffected. Alternatively, when the level of "activism" is included - as proxied by the average number of employed workers involved in a strike - the latter shows a positive and statistically significant impact. ${ }^{53}$ Notice that left voting affects negatively union density.

We also looked at the sensitivity of our results to alternative measures of institutions to the ones used here. We have experimented with an alternative variable for unemployment benefit (replacement rates taken directly from OECD data-set), employment protection measures (from Blanchard and Wolfers 2000 and OECD 1999), centralisation and corporatism (from Nickell et al. 2001). In general, variables based on alternative definitions perform similarly to the one included in our preferred specification, though in some cases the significance level is lower ${ }^{54}$. In conclusion, we find that our preferred estimates are robust to most specification checks.

\footnotetext{
${ }^{53}$ However the interpretation of a strike variable in our specification is not straightforward, as it might be the case that strike activity (particularly when measured, as in our case, by strike participation) is significantly influenced by union density itself. Also, the issue of whether strikes should be considered as an indicator of strong (or weak) bargaining power, is much debated in the literature. For the above reasons we refrain from entering the strike variable in our preferred specification.

${ }^{54}$ It should be noted that we restricted the analysis to time varying institutions for which an equivalent time span exists.
} 
Table A.4.3 - Sensitivity on union density equations: economic shock and time varying institutions - country exclusion

\begin{tabular}{|c|c|c|c|c|c|c|c|c|c|c|c|c|c|}
\hline Model : & 1 & 2 & 3 & 4 & 5 & 6 & 7 & 8 & 9 & 10 & 11 & 12 & 13 \\
\hline $\mathrm{mmm}$ & $\begin{array}{r}0.328 \\
(2.42)\end{array}$ & $\begin{array}{r}0.523 \\
(2.84)\end{array}$ & $\begin{array}{r}0.552 \\
(3.18)\end{array}$ & $\begin{array}{r}0.459 \\
(2.42)\end{array}$ & $\begin{array}{r}0.416 \\
(2.42)\end{array}$ & $\begin{array}{r}0.562 \\
(3.15)\end{array}$ & $\begin{array}{r}0.783 \\
(3.12)\end{array}$ & $\begin{array}{r}0.621 \\
(2.66)\end{array}$ & $\begin{array}{r}0.491 \\
(2.73)\end{array}$ & $\begin{array}{r}0.648 \\
(2.99)\end{array}$ & $\begin{array}{r}0.501 \\
(2.65)\end{array}$ & $\begin{array}{r}0.527 \\
(2.93)\end{array}$ & $\begin{array}{r}0.426 \\
(2.38)\end{array}$ \\
\hline $\mathrm{pa}$ & $\begin{array}{c}0.935 \\
(5.67)\end{array}$ & $\begin{array}{l}1.262 \\
(4.88)\end{array}$ & $\begin{array}{l}1.167 \\
(4.96)\end{array}$ & $\begin{array}{l}1.273 \\
(4.34)\end{array}$ & $\begin{array}{l}1.575 \\
(4.91)\end{array}$ & $\begin{array}{r}1.017 \\
(4.54)\end{array}$ & $\begin{array}{l}1.208 \\
(4.62)\end{array}$ & $\begin{array}{l}1.113 \\
(4.54)\end{array}$ & $\begin{array}{c}1.175 \\
(4.70)\end{array}$ & $\begin{array}{l}1.320 \\
(4.64)\end{array}$ & $\begin{array}{l}1.227 \\
(4.72)\end{array}$ & $\begin{array}{l}1.399 \\
(5.24)\end{array}$ & $\begin{array}{r}1.164 \\
(4.58)\end{array}$ \\
\hline une & $\begin{array}{r}-0.472 \\
(-2.03)\end{array}$ & $\begin{array}{r}-0.273 \\
(-0.85)\end{array}$ & $\begin{array}{r}0.161 \\
(0.53)\end{array}$ & $\begin{array}{r}-0.334 \\
(-1.08)\end{array}$ & $\begin{array}{c}-0.291 \\
(-0.98)\end{array}$ & $\begin{array}{c}-0.205 \\
(-0.69)\end{array}$ & $\begin{array}{r}-0.307 \\
(-1.10)\end{array}$ & $\begin{array}{c}-0.035 \\
(-0.09)\end{array}$ & $\begin{array}{r}-0.202 \\
(-0.65)\end{array}$ & $\begin{array}{r}-0.20 \\
(-0.59)\end{array}$ & $\begin{array}{r}-0.144 \\
(-0.50)\end{array}$ & $\begin{array}{r}-\odot . \odot 4 \odot \\
(-0.14)\end{array}$ & $\begin{array}{r}-0.288 \\
(-0.85)\end{array}$ \\
\hline infl & $\begin{array}{r}0.409 \\
(1.66)\end{array}$ & $\begin{array}{r}0.540 \\
(2.11)\end{array}$ & $\begin{array}{r}0.574 \\
(2.58)\end{array}$ & $\begin{array}{r}0.475 \\
(1.81)\end{array}$ & $\begin{array}{r}0.624 \\
(2.41)\end{array}$ & $\begin{array}{r}0.387 \\
(1.34)\end{array}$ & $\begin{array}{r}0.412 \\
(1.54)\end{array}$ & $\begin{array}{r}0.591 \\
(2.29)\end{array}$ & $\begin{array}{r}0.548 \\
(1.99)\end{array}$ & $\begin{array}{r}0.468 \\
(1.74)\end{array}$ & $\begin{array}{r}0.683 \\
(2.78)\end{array}$ & $\begin{array}{r}0.593 \\
(2.35)\end{array}$ & $\begin{array}{r}0.402 \\
(1.20)\end{array}$ \\
\hline brr & $\begin{array}{r}-0.045 \\
(-1.24)\end{array}$ & $\begin{array}{r}-0.049 \\
(-1.04)\end{array}$ & $\begin{array}{r}-0.078 \\
(-1.89)\end{array}$ & $\begin{array}{r}-0.053 \\
(-1.15)\end{array}$ & $\begin{array}{r}-0.017 \\
(-0.38)\end{array}$ & $\begin{array}{r}-0.007 \\
(-0.15)\end{array}$ & $\begin{array}{c}0.033 \\
(0.60)\end{array}$ & $\begin{array}{r}-0.023 \\
(-0.43)\end{array}$ & $\begin{array}{r}-0.047 \\
(-1.00)\end{array}$ & $\begin{array}{r}-0.056 \\
(-1.27)\end{array}$ & $\begin{array}{r}-0.049 \\
(-1.17)\end{array}$ & $\begin{array}{r}-0.070 \\
(-1.72)\end{array}$ & $\begin{array}{l}-0.007 \\
(-0.12)\end{array}$ \\
\hline bd & $\begin{array}{r}-0.160 \\
(-5.54)\end{array}$ & $\begin{array}{r}-0.097 \\
(-2.27)\end{array}$ & $\begin{array}{r}-0.083 \\
(-2.20)\end{array}$ & $\begin{array}{r}-0.125 \\
(-3.17)\end{array}$ & $\begin{array}{r}-0.065 \\
(-1.48)\end{array}$ & $\begin{array}{r}-0.126 \\
(-3.27)\end{array}$ & $\begin{array}{r}-0.143 \\
(-3.79)\end{array}$ & $\begin{array}{r}-0.129 \\
(-3.34)\end{array}$ & $\begin{array}{r}-0.115 \\
(-2.96)\end{array}$ & $\begin{array}{r}-0.113 \\
(-2.73)\end{array}$ & $\begin{array}{r}-0.097 \\
(-2.04)\end{array}$ & $\begin{array}{r}-0.082 \\
(-1.91)\end{array}$ & $\begin{array}{r}-0.123 \\
(-2.79)\end{array}$ \\
\hline ep & $\begin{array}{r}-0.055 \\
(-2.77)\end{array}$ & $\begin{array}{r}-0.096 \\
(-3.39)\end{array}$ & $\begin{array}{r}-0.134 \\
(-5.03)\end{array}$ & $\begin{array}{r}-0.099 \\
(-3.66)\end{array}$ & $\begin{array}{r}-0.092 \\
(-3.56)\end{array}$ & $\begin{array}{c}-0.091 \\
(-3.48)\end{array}$ & $\begin{array}{r}-0.086 \\
(-3.35)\end{array}$ & $\begin{array}{c}-0.081 \\
(-3.17)\end{array}$ & $\begin{array}{r}-0.089 \\
(-2.70)\end{array}$ & $\begin{array}{r}-0.094 \\
(-3.35)\end{array}$ & $\begin{array}{r}-0.084 \\
(-2.99)\end{array}$ & $\begin{array}{l}-0.061 \\
(-2.50)\end{array}$ & $\begin{array}{c}-0.093 \\
(-3.66)\end{array}$ \\
\hline centr & $\begin{array}{r}-0.151 \\
(-3.15)\end{array}$ & $\begin{array}{r}-0.066 \\
(-0.86)\end{array}$ & $\begin{array}{r}-0.042 \\
(-0.71)\end{array}$ & $\begin{array}{r}-0.108 \\
(-1.85)\end{array}$ & $\begin{array}{r}-0.070 \\
(-1.22)\end{array}$ & $\begin{array}{r}-0.092 \\
(-1.45)\end{array}$ & $\begin{array}{r}-0.155 \\
(-2.35)\end{array}$ & $\begin{array}{r}-0.048 \\
(-0.56)\end{array}$ & $\begin{array}{r}-0.098 \\
(-1.58)\end{array}$ & $\begin{array}{r}-0.111 \\
(-1.58)\end{array}$ & $\begin{array}{r}-0.114 \\
(-1.86)\end{array}$ & $\begin{array}{r}-\odot .084 \\
(-1.34)\end{array}$ & $\begin{array}{r}-0.086 \\
(-1.32)\end{array}$ \\
\hline index & $\begin{array}{r}-0.038 \\
(-2.38)\end{array}$ & $\begin{array}{r}-\odot .024 \\
(-1.0 \odot)\end{array}$ & $\begin{array}{r}-0.044 \\
(-2.20)\end{array}$ & $\begin{array}{r}-0.038 \\
(-1.78)\end{array}$ & $\begin{array}{r}-0.035 \\
(-1.75)\end{array}$ & $\begin{array}{r}-0.042 \\
(-2.12)\end{array}$ & $\begin{array}{r}-\odot .031 \\
(-1.50)\end{array}$ & $\begin{array}{r}-0.041 \\
(-1.91)\end{array}$ & $\begin{array}{r}-0.033 \\
(-1.59)\end{array}$ & $\begin{array}{r}-0.028 \\
(-1.10)\end{array}$ & $\begin{array}{r}-0.030 \\
(-1.42)\end{array}$ & $\begin{array}{r}-0.023 \\
(-1.14)\end{array}$ & $\begin{array}{r}-0.036 \\
(-1.37)\end{array}$ \\
\hline work & $\begin{array}{r}0.127 \\
(2.36)\end{array}$ & $\begin{array}{r}0.187 \\
(4.03)\end{array}$ & $\begin{array}{r}0.163 \\
(3.53)\end{array}$ & $\begin{array}{r}0.185 \\
(4.01)\end{array}$ & $\begin{array}{r}0.150 \\
(3.82)\end{array}$ & $\begin{array}{r}0.184 \\
(2.67)\end{array}$ & $\begin{array}{r}0.324 \\
(3.43)\end{array}$ & $\begin{array}{c}0.176 \\
(3.57)\end{array}$ & $\begin{array}{c}0.196 \\
(3.98)\end{array}$ & $\begin{array}{r}0.177 \\
(3.75)\end{array}$ & $\begin{array}{r}0.186 \\
(4.14)\end{array}$ & $\begin{array}{c}0.196 \\
(4.12)\end{array}$ & $\begin{array}{r}0.188 \\
(3.97)\end{array}$ \\
\hline tw & $\begin{array}{r}0.322 \\
(4.02)\end{array}$ & $\begin{array}{r}0.438 \\
(2.98)\end{array}$ & $\begin{array}{r}0.283 \\
(2.11)\end{array}$ & $\begin{array}{r}0.536 \\
(3.18)\end{array}$ & $\begin{array}{r}0.243 \\
(1.60)\end{array}$ & $\begin{array}{r}0.532 \\
(3.57)\end{array}$ & $\begin{array}{r}0.376 \\
(2.69)\end{array}$ & $\begin{array}{r}0.450 \\
(3.16)\end{array}$ & $\begin{array}{r}0.451 \\
(3.12)\end{array}$ & $\begin{array}{r}0.472 \\
(2.96)\end{array}$ & $\begin{array}{r}0.450 \\
(3.05)\end{array}$ & $\begin{array}{r}0.358 \\
(2.54)\end{array}$ & $\begin{array}{r}0.408 \\
(2.65)\end{array}$ \\
\hline Constant & Yes & Yes & Yes & Yes & Yes & Yes & Yes & Yes & Yes & Yes & Yes & Yes & Yes \\
\hline Definition & Yes & Yes & Yes & Yes & Yes & Yes & Yes & Yes & Yes & Yes & Yes & Yes & Yes \\
\hline Countries & Yes & Yes & Yes & Yes & Yes & Yes & Yes & Yes & Yes & Yes & Yes & Yes & Yes \\
\hline Year & Yes & Yes & Yes & Yes & Yes & Yes & Yes & Yes & Yes & Yes & Yes & Yes & Yes \\
\hline $\begin{array}{l}\mathrm{R}^{2} \\
\# \text { obs : }\end{array}$ & $\begin{array}{c}0.98 \\
96\end{array}$ & $\begin{array}{c}0.965 \\
96\end{array}$ & $\begin{array}{c}0.964 \\
96\end{array}$ & $\begin{array}{c}0.961 \\
96\end{array}$ & $\begin{array}{c}0.968 \\
96\end{array}$ & $\begin{array}{c}0.966 \\
96\end{array}$ & $\begin{array}{c}0.969 \\
96\end{array}$ & $\begin{array}{c}0.966 \\
96\end{array}$ & $\begin{array}{c}0.963 \\
96\end{array}$ & $\begin{array}{c}0.963 \\
96\end{array}$ & $\begin{array}{c}0.968 \\
96\end{array}$ & $\begin{array}{c}0.963 \\
96\end{array}$ & $\begin{array}{c}0.962 \\
96\end{array}$ \\
\hline
\end{tabular}

Notes: robust t-statistics in parentheses - variable legend in table 3 -

Model 1: no Finland Model 2: no Belgium Model 3: no Sweden

Model 4: no Denmark
Model 5: no Norway Model 6: no Italy Model 7: no UK
Model 9: no Germany Model 10: no Netherlands Model 11: no Austria
Model 13: no Switzerland 
Table A.4.4 - Sensitivity checks: institutions entered individually

\begin{tabular}{|c|c|c|}
\hline $\begin{array}{l}\text { Model : } \\
\# \text { obs : }\end{array}$ & $\begin{array}{c}1 \\
104\end{array}$ & $\begin{array}{c}2 \\
104\end{array}$ \\
\hline brr & $\begin{array}{r}-0.199 \\
(-3.12)\end{array}$ & $\begin{array}{r}\odot .0 \odot \odot \\
(-\odot .01)\end{array}$ \\
\hline bd & $\begin{array}{r}0.075 \\
(1.38)\end{array}$ & $\begin{array}{c}-\odot .032 \\
(-0.57)\end{array}$ \\
\hline ep & $\begin{array}{c}-\odot .0 \odot 8 \\
(-0.37)\end{array}$ & $\begin{array}{r}-0.075 \\
(-2.44)\end{array}$ \\
\hline centr & $\begin{array}{r}0.498 \\
(5.26)\end{array}$ & $\begin{array}{r}0.034 \\
(0.44)\end{array}$ \\
\hline index & $\begin{array}{r}0.013 \\
(0.36)\end{array}$ & $\begin{array}{c}-0.054 \\
(-2.20)\end{array}$ \\
\hline work & $\begin{array}{r}0.403 \\
(6.31)\end{array}$ & $\begin{array}{r}0.124 \\
(2.15)\end{array}$ \\
\hline tw & $\begin{array}{r}0.003 \\
(0.03)\end{array}$ & $\begin{array}{r}0.082 \\
(0.54)\end{array}$ \\
\hline herf & $\begin{array}{r}0.20 \\
(3.18)\end{array}$ & $\begin{array}{r}0.164 \\
(1.70)\end{array}$ \\
\hline open & $\begin{array}{l}15.625 \\
(2.39)\end{array}$ & $\begin{array}{r}6.608 \\
(0.87)\end{array}$ \\
\hline Constant & Yes & Yes \\
\hline Definition & Yes & Yes \\
\hline $\begin{array}{l}\text { Year } \\
\text { Countries }\end{array}$ & Yes & $\begin{array}{l}\text { Yes } \\
\text { Yes }\end{array}$ \\
\hline Controls & Yes & Yes \\
\hline
\end{tabular}

Notes: robust t-statistics in parentheses - variable legend in table 3 controls include UNE, INFL, PA, and MMM. 
Table A.4.5- Union Density, Economic Shocks and Time Varying Institutions with Political variables -13 countries $-1960-2000$

\begin{tabular}{|c|c|c|c|}
\hline Model : & 1 & 2 & 3 \\
\hline $\log (p o p)$ & $\begin{array}{r}-0.030 \\
(-2.61)\end{array}$ & $\begin{array}{r}-0.026 \\
(-2.32)\end{array}$ & $\begin{array}{c}-0.030 \\
(-2.61)\end{array}$ \\
\hline $\mathrm{mmm}$ & $\begin{array}{r}0.585 \\
(3.39)\end{array}$ & $\begin{array}{r}0.773 \\
(4.48)\end{array}$ & $\begin{array}{r}0.796 \\
(4.51)\end{array}$ \\
\hline une & $\begin{array}{r}-0.575 \\
(-1.77)\end{array}$ & $\begin{array}{r}-0.659 \\
(-1.95)\end{array}$ & $\begin{array}{l}-0.662 \\
(-1.99)\end{array}$ \\
\hline infl & $\begin{array}{r}0.279 \\
(0.99)\end{array}$ & $\begin{array}{r}0.177 \\
(0.59)\end{array}$ & $\begin{array}{r}-0.077 \\
(-0.25)\end{array}$ \\
\hline brr & 0.003 & $\odot .0 \odot 2$ & 0.029 \\
\hline & $(0.07)$ & $(0.05)$ & $(0.63)$ \\
\hline bd & $\begin{array}{r}-0.217 \\
(-6.45)\end{array}$ & $\begin{array}{r}-0.221 \\
(-6.37)\end{array}$ & $\begin{array}{r}-0.217 \\
(-6.46)\end{array}$ \\
\hline ep & $\begin{array}{l}-0.068 \\
(-2.70)\end{array}$ & $\begin{array}{r}-0.054 \\
(-2.42)\end{array}$ & $\begin{array}{l}-0.049 \\
(-2.13)\end{array}$ \\
\hline centr & $\begin{array}{l}-0.040 \\
(-0.63)\end{array}$ & $\begin{array}{r}-0.079 \\
(-1.27)\end{array}$ & $\begin{array}{l}-0.074 \\
(-1.22)\end{array}$ \\
\hline ghent & $\begin{array}{r}0.263 \\
(10.55)\end{array}$ & $\begin{array}{r}0.254 \\
(11.40)\end{array}$ & $\begin{array}{r}0.254 \\
(11.69)\end{array}$ \\
\hline index & $\begin{array}{r}-0.065 \\
(-3.98)\end{array}$ & $\begin{array}{r}-0.070 \\
(-4.42)\end{array}$ & $\begin{array}{l}-0.064 \\
(-4.05)\end{array}$ \\
\hline work & $\begin{array}{r}0.173 \\
(3.89)\end{array}$ & $\begin{array}{r}0.268 \\
(5.87)\end{array}$ & $\begin{array}{r}0.258 \\
(6.13)\end{array}$ \\
\hline tw & $\begin{array}{r}0.416 \\
(4.27)\end{array}$ & $\begin{array}{r}0.516 \\
(5.03)\end{array}$ & $\begin{array}{r}0.501 \\
(5.03)\end{array}$ \\
\hline kaitz & $\begin{array}{r}1.660 \\
(7.82)\end{array}$ & $\begin{array}{r}1.328 \\
(5.90)\end{array}$ & $\begin{array}{r}1.216 \\
(4.95)\end{array}$ \\
\hline mandat & $\begin{array}{r}-0.559 \\
(-8.35)\end{array}$ & $\begin{array}{r}-0.440 \\
(-5.74)\end{array}$ & $\begin{array}{r}-0.428 \\
(-5.47)\end{array}$ \\
\hline pa & $\begin{array}{r}0.677 \\
(3.91)\end{array}$ & $\begin{array}{r}0.532 \\
(3.15)\end{array}$ & $\begin{array}{r}0.553 \\
(3.35)\end{array}$ \\
\hline mkregd & $\begin{array}{r}-0.041 \\
(-3.54)\end{array}$ & $\begin{array}{l}-0.041 \\
(-3.61)\end{array}$ & $\begin{array}{r}-0.040 \\
(-3.67)\end{array}$ \\
\hline open & $\begin{array}{r}4.801 \\
(0.99)\end{array}$ & $\begin{array}{r}3.382 \\
(0.68)\end{array}$ & $\begin{array}{r}4.025 \\
(0.86)\end{array}$ \\
\hline herf & $\begin{array}{r}0.149 \\
(3.66)\end{array}$ & $\begin{array}{r}0.166 \\
(4.19)\end{array}$ & $\begin{array}{r}0.190 \\
(4.91)\end{array}$ \\
\hline leftv & & $\begin{array}{l}-42.768 \\
(-2.92)\end{array}$ & $\begin{array}{l}-41.413 \\
(-3.12)\end{array}$ \\
\hline strike & & & $\begin{array}{r}0.135 \\
(2.44)\end{array}$ \\
\hline Constant & Yes & Yes & Yes \\
\hline Definition & Yes & Yes & Yes \\
\hline Year & Yes & Yes & Yes \\
\hline $\mathrm{R}^{2}$ & 0.938 & 0.946 & 0.949 \\
\hline
\end{tabular}


Table A.4.6 - Factor analysis on labour market institutions - 13 countries - 1960-2000 104 observations

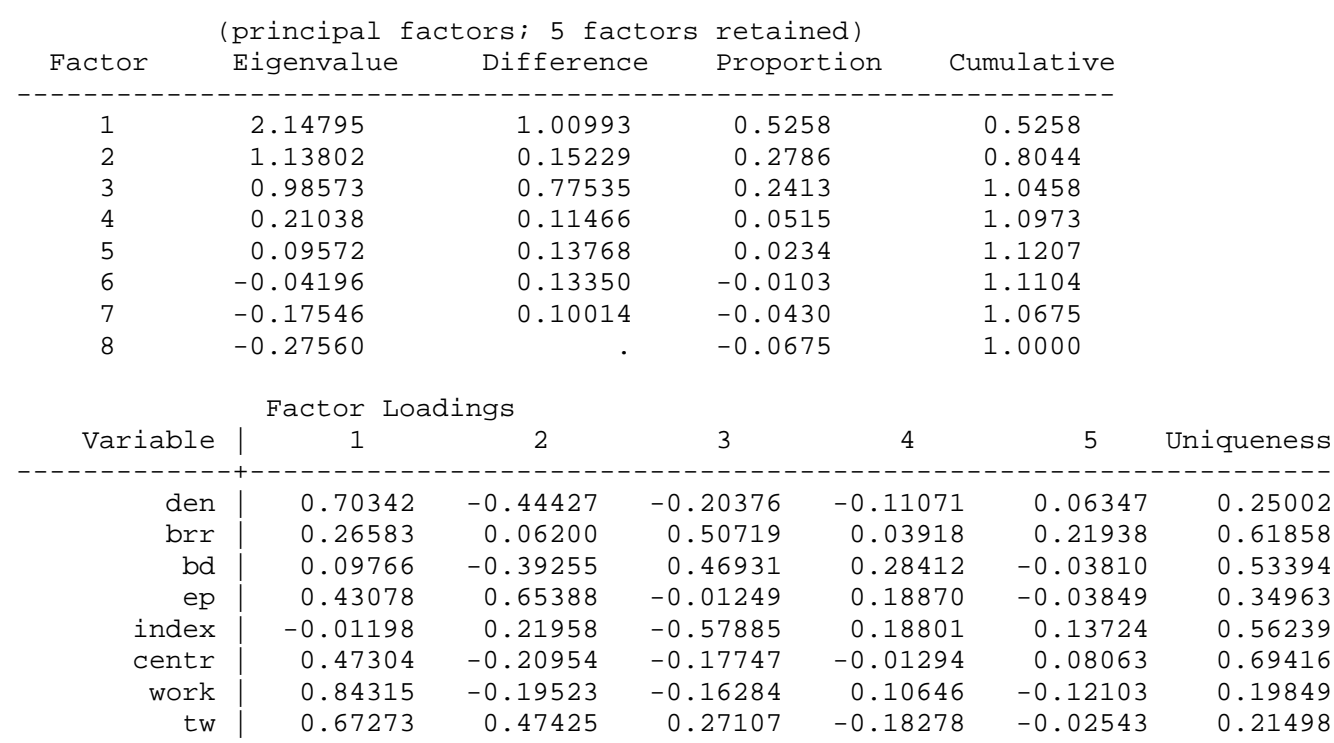

